
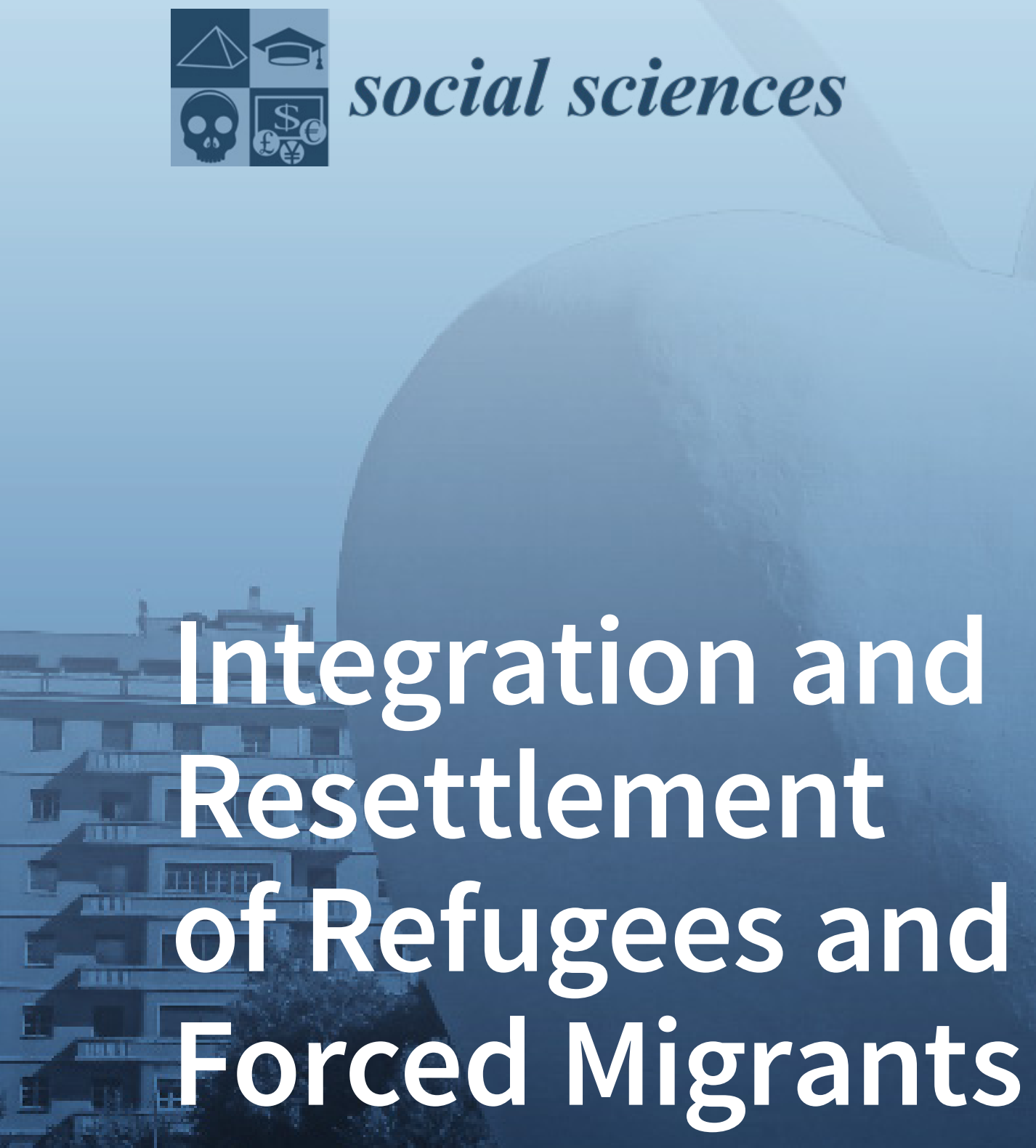

Edited by

Karen Jacobsen and Charles Simpson Printed Edition of the Special Issue Published in Social Sciences

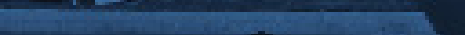




\section{Integration and Resettlement of Refugees and Forced Migrants}





\section{Integration and Resettlement of Refugees and Forced Migrants}

Special Issue Editors

Karen Jacobsen

Charles Simpson 
Special Issue Editors

Karen Jacobsen

Tufts University

USA
Charles Simpson

Tufts University

USA

Editorial Office

MDPI

St. Alban-Anlage 66

4052 Basel, Switzerland

This is a reprint of articles from the Special Issue published online in the open access journal Social Sciences (ISSN 2076-0760) in 2019 (available at: https://www.mdpi.com/journal/socsci/ special_issues/integration_and_resettlement_of_refugees).

For citation purposes, cite each article independently as indicated on the article page online and as indicated below:

LastName, A.A.; LastName, B.B.; LastName, C.C. Article Title. Journal Name Year, Article Number, Page Range.

\section{ISBN 978-3-03928-130-5 (Pbk)}

ISBN 978-3-03928-131-2 (PDF)

Cover image courtesy of Charles Simpson.

(C) 2020 by the authors. Articles in this book are Open Access and distributed under the Creative Commons Attribution (CC BY) license, which allows users to download, copy and build upon published articles, as long as the author and publisher are properly credited, which ensures maximum dissemination and a wider impact of our publications.

The book as a whole is distributed by MDPI under the terms and conditions of the Creative Commons license CC BY-NC-ND. 


\section{Contents}

About the Special Issue Editors $\ldots \ldots \ldots \ldots \ldots \ldots \ldots \ldots$ vii

Preface to "Integration and Resettlement of Refugees and Forced Migrants" . . . . . . . . ix

Martina Blank

"Wir Schaffen Das!"? Spatial Pitfalls of Neighborhood-Based Refugee Reception in Germany-A Case Study of Frankfurt-Rödelheim

Reprinted from: Soc. Sci. 2019, 8, 161, doi:10.3390/socsci8050161 . . . . . . . . . . . . . 1

\section{Matthias Flug and Jason Hussein}

Integration in the Shadow of Austerity—Refugees in Newcastle upon Tyne

Reprinted from: Soc. Sci. 2019, 8, 212, doi:10.3390/socsci8070212 . . . . . . . . . . . . . . 16

Teodora Jovanović

Formal Education of Asylum Seeker Children in Belgrade, Serbia: Expanded Meaning of Social Inclusion

Reprinted from: Soc. Sci. 2019, 8, 211, doi:10.3390/socsci8070211 _ . . . . . . . . . . . 33

\section{Rafik Arfaoui}

The Asylum Seekers in Non-Metropolitan Areas in France: Between Temporary Integration and Leading to Autonomy. The Case of the Ambertois Territory

Reprinted from: Soc. Sci. 2019, 8, 210, doi:10.3390/socsci8070210 . . . . . . . . . . . . . . . 44

\section{Rosella Bianco and Mónica Ortiz Cobo}

The Linguistic Integration of Refugees in Italy

Reprinted from: Soc. Sci. 2019, 8, 284, doi:10.3390/socsci8100284 _ . . . . . . . . . . . . . 58

\section{Annie Taccolini Pannagio and Odessa Gonzalez Benson}

"And Slowly, the Integration and the Growing and the Learning": Nuanced Notions of Integration of Bhutanese Refugees in US Cities

Reprinted from: Soc. Sci. 2019, 8, 181, doi:10.3390/socsci8060181 . . . . . . . . . . . . . . 73

\section{Daniel B. Robinson, Ingrid M. Robinson, Vanessa Currie and Nathan Hall}

The Syrian Canadian Sports Club: A Community-Based Participatory Action Research Project with/for Syrian Youth Refugees

Reprinted from: Soc. Sci. 2019, 8, 163, doi:10.3390/socsci8060163 . . . . . . . . . . . . . . . 84 



\section{About the Special Issue Editors}

Karen Jacobsen (Henry J. Leir Professor in Global Migration, The Fletcher School of Law and Diplomacy, Tufts University) directs the Refugees in Towns Project at the Feinstein International Center. Professor Jacobsen's current research explores the impact of urban displacement on cities, and the links between climate change, environmental degradation and migration. In 2013-2014, she led the Joint IDP Profiling Service (JIPS) in Geneva while on leave from Tufts. During 2000-2005, she directed the Alchemy Project, which explored the use of microfinance as a way to support people in refugee camps and other displacement settings.

Charles Simpson (Program Administrator, Refugees in Towns Project, Feinstein International Center, Tufts University). For the Refugees in Towns Project, Charles develops the project methodology and case studies in addition to managing relationships with researchers, participants, and experts. Prior to joining the Feinstein International Center, he was Assistant Director of the Boston Consortium for Arab Region Studies (BCARS), a Carnegie Corporation project. At BCARS, he managed policy analysis, field research teams, workshops, and conferences on the Syrian refugee crisis in the Middle East, Turkey, the Balkans, the EU, and the US. 



\section{Preface to "Integration and Resettlement of Refugees and Forced Migrants"}

In 2017, the United States and Europe-among many other refugee-hosting countries-made significant changes in their refugee policies. New regulations in the form of visa restrictions, travel bans, and other constraints were imposed by national governments. At the local level, towns responded in different ways: some resisted national policy changes by declaring themselves "sanctuary cities", while others supported exclusionary policies. These different responses affected refugees' ability to settle and become integrated, as did many other factors in cities and towns. We started the Refugees in Towns (RIT) project—based at Tufts University-with the idea of exploring local urban integration experiences by drawing on the knowledge and perspectives of refugees and citizens living in towns around the world. Since the RIT project began in mid-2017, we have commissioned more than 30 case studies, giving a voice to many refugees and hosts in an effort to deepen our understanding of urban integration. We are building a global database of cases that share local knowledge and perspectives about the factors that enable or obstruct integration, and the ways in which migrants and hosts co-exist, adapt, and struggle with integration. Our goal is to support community leaders, aid organizations, and local governments in shaping policy, practice, and interventions, and to build a theory of integration from the ground up. In this Special Issue, seven articles explore urban integration in the cities and towns of Europe, the US, and Canada. The papers explore how refugees and citizens interact in the authors' towns; the role of officials and politicians in enabling or obstructing integration; the social, economic, and cultural impact of migration on hosting towns; and the ways-inclusive or exclusive-locals have responded to immigration. The first five articles explore European cities: Frankfurt-Rödelheim, Germany; Newcastle, UK; Ambertois, France; Italy's cities; and Belgrade, Serbia. The final two articles look at North American cities: Bhutanese refugee-hosting US cities, and the Syrian refugee-hosting town of Antigonish, Canada.

Karen Jacobsen, Charles Simpson

Special Issue Editors 

Article

\title{
“Wir Schaffen Das!"? Spatial Pitfalls of Neighborhood-Based Refugee Reception in Germany-A Case Study of Frankfurt-Rödelheim
}

\author{
Martina Blank \\ Department of Human Geography, Goethe-University Frankfurt, Theodor-W.-Adorno-Platz 6, \\ D-60629 Frankfurt am Main, Germany; mblank@em.uni-frankfurt.de; Tel.: +49-69-798-35184
}

Received: 12 April 2019; Accepted: 21 May 2019; Published: 27 May 2019

\begin{abstract}
Refugee reception in Germany is a primarily municipal task that relies heavily on neighborhood-based volunteering. This paper asserts that there are fundamental spatial mismatches between municipal policies and neighborhood-based approaches that place additional burden on all of the stakeholders involved. Drawing from the case of Frankfurt-Rödelheim, which is a socially and ethnically mixed neighborhood in Frankfurt am Main, I show how the way the municipality accommodates refugees disregards the politically embraced work of neighborhood-based volunteers and how the ideal of neighborhood-based inclusion creates a spatial fetish that fails the living reality of the refugees. The findings are based on my ethnographic fieldwork as volunteer in a neighborhood-based welcome initiative.
\end{abstract}

Keywords: forced migration; local refugee reception; refugee accommodation; municipalities; neighborhood activism; Germany; Frankfurt am Main

\section{Introduction}

When more than one million refugees arrived in Europe in 2015, German chancellor Angela Merkel famously responded with "Wir schaffen das!" ("We can do this!"). However, the "we" who "did it" were the local authorities and civil society, rather than the national government. In fact, refugee reception was a primarily municipal task that relied heavily on neighborhood-based volunteering. This paper asserts that there are fundamental mismatches between the municipal policies and neighborhood-based approaches that place additional burden on all of the stakeholders involved.

Asylum seekers are required to register with a state organization in order to apply for asylum when they arrive in Germany. The Federal Office for Migration and Refugees (BAMF) registered 476,649 asylum applications in 2015, 745,545 in 2016, 222,683 in 2017, and 185,853 in 2018 (BAMF 2019, p. 6). Processing the application can take years. In the interim, asylum seekers receive basic housing, food, education, healthcare, and a small stipend to cover their everyday personal needs. The government accommodates the asylum seekers during the asylum evaluation. First, registered refugees are distributed to one of the 16 federal states according to a quota system, and the correspondent federal state's government provides housing for refugees in reception facilities for up to six months or until the application is decided upon. Thereafter, asylum seekers are assigned by the federal state in question to its constituent municipalities and they are obliged to reside in the assigned municipality until the conclusion of the asylum proceedings.

Municipalities are primarily responsible for "doing it" during these initial stages of the asylum seekers' reception in Germany: they are required to provide housing and basic protection for the refugees and to facilitate their social and economic inclusion. Municipalities are partly reimbursed by the federal and regional governments, but the management of the reception of asylum seekers is essentially a local task, whereby each municipality must respond to the conditions that are relevant to 
their own local context (Schammann 2015; Schammann and Kühn 2016). Providing affordable housing, for example, is especially difficult for larger German cities that are already suffering from housing shortages. As a greater influx of migrants entered Europe from 2015 onwards, many cities relied on emergency planning, resorting to collective and mass accommodation centers in order to fill the gaps.

However, cities do not only have to help refugees meet their basic needs, but they are also expected to facilitate the social and economic inclusion of the asylum seekers. This is the point at which neighborhoods come into play. Neighborhood-based integration of immigrants has been widely discussed in academic debates and local politics for several years (Schnur 2018). German immigration policy remained highly underdeveloped at the national level for many decades (Bendel and Borkowski 2016). Meanwhile, local authorities, especially those of big West German cities with high levels of immigration, and migrant communities themselves managed migration at an everyday level and developed their own integration policies (Pütz and Rodatz 2013; Gesemann and Roth 2018). Of special importance for these policies was the everyday living environment of migrants was (Schnur et al. 2013), which became to be considered to be the level where the problems of inclusion became most apparent. Later, a rising political and academic preoccupation with ethnic segregation and discourses on "parallel societies" and "ghettos" (Ronneberger and Tsianos 2009; Yildiz 2014) reinforced this focus on the residential areas of migrants. Thereby, the neighborhood came to be considered as one of the most prominent gateways to integration-also being acknowledged in the Federal Integration Plan of 2007, where the neighborhood level plays a vital role (Bundesregierung 2007).

The recent arrival of greater numbers of refugees has prompted a politically-embraced surge of neighborhood-based volunteering for migrant reception. During the "long summer of migration" (Hess et al. 2017), new volunteering initiatives emerged all over Germany (Hamann et al. 2017). Most of these "welcome initiatives" developed spontaneously and independently of traditional civil society organizations working with migrants (Karakayali and Kleist 2016) and many organized themselves at the local level as neighborhood initiatives. They filled the gaps that were left by state authorities and offered assistance to asylum seekers by teaching German and supporting refugees in their everyday needs. However, the new volunteers have been criticized for failing to develop participatory approaches for the active participation and inclusion of refugees (Fleischmann and Steinhilper 2017, pp. 21-22). This critique considers the paternalistic practices of helping within some volunteering initiatives as rooted in a "new dispositif of helping" (ibid.).

Nevertheless, as I argue in this paper, inclusionary refugee reception at the local level is also restrained by spatial mismatches between the state policies, volunteering, and living conditions of refugees. These spatial mismatches originate in a national reception system that obliges refugees to reside for years in places that are not freely selected, waiting for the final decision on their asylum application and the subsequent opportunity to settle in the place of their choice. The resulting discrepancy between the demand to integrate, as well as the temporariness and lack of voluntariness and agency on behalf of the refugees, is scaled down to the municipalities and is left to their response. The resulting difficulties are reproduced in the "local production of asylum", as I am going to show for the case of Frankfurt am Main (Hinger et al. 2016).

The dominant system of asylum is negotiated locally through the social production of specific spaces of asylum that materialize the complex and place-specific social processes accompanying the arrival of refugees in German cities, as argued elsewhere (Blank 2019). In this paper, the focus lies on the socio-spatial dynamics resulting from the current form of accommodation. In the case of Frankfurt am Main, a dearth of sufficient housing prompted the city council to abandon its plan of decentralized refugee accommodation, and the city instead established a series of collective accommodation centers (Frankfurter Stadtverordnetenversammlung 2017, pp. 2, 5, 6). Many of these centers are located in industrial areas that are away from non-refugee residents, thereby creating a spatial exclusion and segregation of refugees. This practice contradicts the official political discourse of Frankfurt as a city that fosters inclusion and diversity (Stadt Frankfurt am Main 2011). Nevertheless, in many 
circumstances, civil society demonstrates a great effort to include the asylum seekers in the social fabric of the adjacent neighborhoods. Drawing from the case of Frankfurt-Rödelheim, a socially and ethnically mixed neighborhood in Frankfurt am Main, I am going to show how the way the municipality accommodates refugees disregards the politically embraced work of neighborhood-based volunteers and how the ideal of neighborhood-based inclusion creates a spatial fetish, i.e., an obfuscating spatial abstraction of social relations, which fails the living reality of the refugees.

The findings are based on my ethnographic fieldwork as volunteer in a neighborhood-based welcome initiative since November 2017. Ethnography has proved to be a useful approach in the complexity of migration regimes (Hess and Tsianos 2010). In line with grounded theory approaches (Bryant and Charmaz 2007), ethnographic methods, like participant observation and "ero-epic" conversations (Girtler 2001, pp. 147-68), enabled me to develop my understanding of local refugee reception in Frankfurt "on the ground", i.e., as close as possible to the everyday practices of the people involved (Müller 2013). At the same time, ethnography served as methodology to reflect my situatedness in the field (Browne et al. 2010; Clarke 2005; Rose 1997), i.e., how my own perspective and the practices and self-representations of the other actors that are involved related to my position as a female German academic volunteer and the power relations embedded in the field. Though the above-mentioned "dispositif of helping" implies hierarchical power relations between volunteers and refugees, researching as a volunteer also meant getting in touch with refugees on a basis of support and assistance. On the one hand, this facilitated developing trustful research relationships, which was of special importance in the context of pending asylum proceedings and the threat of deportation (Hugman et al. 2011). On the other hand, as a volunteering researcher, I could give something in return to the information that was obtained by the players: self-critical knowledge production to my co-volunteers and practical support to the refugees involved.

I volunteered Monday to Friday afternoons as tutor for homework, German language, and literacy in two Christian community centers and two accommodation centers for refugees between November 2017 and June 2018 (Figure 1). In addition, I participated in volunteered leisure activities with refugees, like cooking and attending festivals. I attended the monthly plenary meeting of the volunteering network and other public meetings regarding the reception of refugees in Rödelheim for more than one year (November 2017-December 2018). I developed more intense relationships with particular refugees and assisted them with local authorities, administrative burdens, looking for flats, funding language courses, professional development, and so forth during the course of my fieldwork. I have accepted refugee invitations to join them in their living spaces in the accommodation centers and refugees have visited me at work and at home. I developed one very close relationship to one woman, who, to date, visits me weekly at my home for tutoring and professional development. In order to reflect on my personal entanglement with the subjects of my research I was supervised by a professional coacher specialized in questions of ethics in research and experiences with violence through a program co-developed on the occasion of my research, which is now provided by the university to researchers in similar situations. I kept detailed field notes regarding my conservations with refugees, volunteers, staff members of the accommodation centers, the district manager, members of the municipal unit for refugee accommodation, social workers, and volunteers from other places. I notified all of them of the study and they provided consent to participate. Additionally, I conducted two group interviews with the volunteers of the network, and four in-depth interviews with the district management, the coordinators of a university-based volunteering group, and two social workers in the field. The collection and analysis of the material followed the considerations of situational analysis by Clarke (2005), combined with content analysis following Kuckartz (2016). I summarize my findings in the form of anonymized, aggregated data in the following account. 


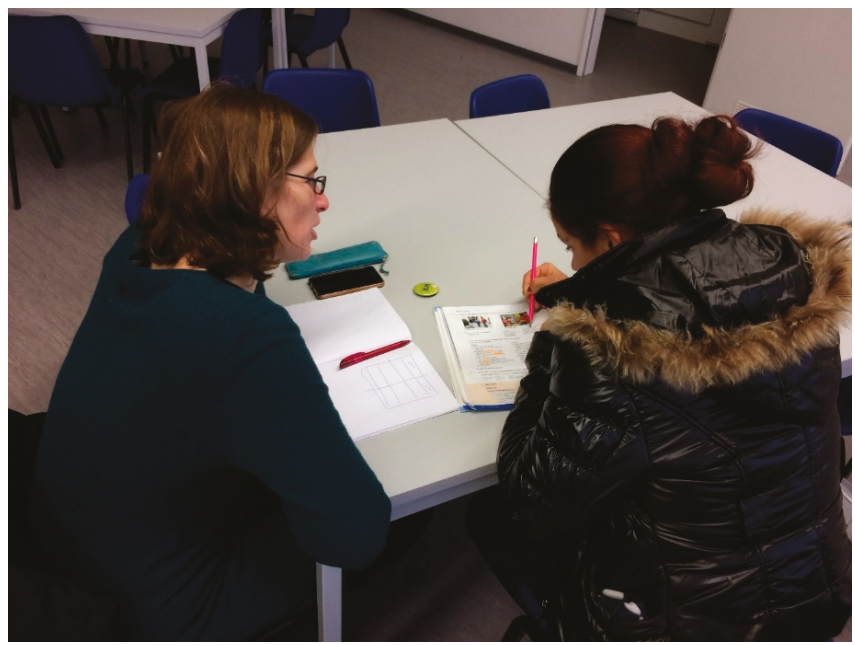

Figure 1. The author volunteering with homework tutoring (photo credit: Udo Schoeler).

\section{Refugee Reception in Frankfurt}

Frankfurt has a long history of hosting migrants and it has always had immigrant minorities. Most prominently, the former Imperial Free City of Frankfurt had one of the earliest and largest Jewish communities in Germany dating back to medieval times. The Jewish community was concentrated in a ghetto from 1462 until 1811 despite living under the declared protection of the Emperor. Later, Frankfurt granted civic equality to Jews in 1864 until "the assimilated Jewish community—one of the largest in Germany-was completely deported after the final pogrom in 1938" (Radtke 2003). Moreover, Frankfurt has a long history as a "cosmopolitan commercial town" (Welz 1998), with the Frankfurt Trade Fair first being mentioned in 1150. Since then, Frankfurt has hosted international trading and financial elites and expatriates from mostly western countries. The biggest part of the migrant population living in today's Frankfurt dates back to the formal guest worker program from 1955 onwards, when Germany signed bilateral recruitment agreements that allowed the recruitment of guest workers from Italy, Spain, Greece, Turkey, Morocco, Portugal, Tunisia, and Yugoslavia to work in the growing industry (ibid., 37). Since the 1980s, there are also growing numbers of immigrants from other world regions, such as Latin America, Africa, and Asia (ibid.). With the exception of the medieval Jewish ghetto, Frankfurt did not develop ethnically segregated immigrant neighborhoods, as known from other western metropoles (ibid., 38). In 1989, as the first municipality in Germany, it established an Office for Multicultural Affairs and it has since adopted relatively progressive immigration policies (Stadt Frankfurt am Main 2011), although experts have criticized the municipality for its insufficient efforts to implement effective policies for anti-discrimination and inclusion (Radtke 2003; Rodatz 2014). Today, Frankfurt is one of Germany's first majority-minority cities. According to the statistical yearbook of 2018, in 2017 29.5\% of the people living in Frankfurt were foreigners and 23.6\% were Germans from an immigrant background, referring to Germans that are born abroad and minors with parents born abroad (Bürgeramt 2018, p. 1).

In 2015, the federal state of Hesse commissioned the city of Frankfurt with emergency supplies for 1000 refugees and, additionally, and in line with the allocation process, assigned 170 asylum seekers per week to the municipality. In order to deal with this situation, the mayor established the "Stabsstelle Flüchtlingsmanagement", a new special municipal unit for refugee administration (Frankfurter Stadtverordnetenversammlung 2017, p. 2). Since then, the provision of adequate shelter has been one of the most challenging issues facing the municipality. The city of Frankfurt favors, in principal, the accommodation of refugees in private apartments with the objective of fostering 
independence and self-sufficiency although collective reception facilities are standard in municipal accommodation of refugees in Germany (Frankfurter Stadtverordnetenversammlung 2017, p. 6). However, this is not the current practice of refugee reception in Frankfurt. Up until the summer of 2015, the city of Frankfurt had mainly resorted to decentralized accommodation of refugees in the already-existing facilities for homeless persons (Frankfurter Stadtverordnetenversammlung 2017, p. 5). From September 2015 onwards, due to the sudden rise in numbers of asylum seekers newly arriving in Frankfurt, the municipality built new collective accommodation centers exclusively for refugees (Frankfurter Stadtverordnetenversammlung 2017, p. 5).

In February 2019, the municipality of Frankfurt officially hosted 4768 refugees in 90 accommodation facilities and 120 private apartments that were scattered all over Frankfurt. About two-thirds of the refugees are men and one-third are women. The primary countries of origin are Afghanistan (33\%), Eritrea (20\%), Syria (19\%), Iraq (6\%), and Iran (6\%). Additionally, there are 366 unaccompanied minors that are registered in Frankfurt (Stabsstelle Flüchtlingsmanagement 2019a). Many of the refugees still reside in one of four emergency accommodation centers, where there is little space for privacy and no facilities for self-provisioning, and nine temporary accommodation centers with more than 100 residents each. This includes a rising number of asylum seekers whose application has already been accepted (and thus are allowed to move around in Frankfurt as they wish) but cannot find private apartments due to the financial and racial exclusions of the housing market. Thus, these refugees are forced to stay in the accommodation centers for much longer than officially planned. According to the guidelines of the municipality, refugees ought not to reside in emergency accommodation centers for more than one year (Frankfurter Stadtverordnetenversammlung 2017, p. 5). Hence, the municipality repeatedly reallocates refugees to slightly better accommodation centers in order to improve the living situation of the asylum seekers at least gradually. These relocations usually imply moving from one neighborhood to another.

Social welfare organizations run the accommodation centers on behalf of the municipality. Aside from providing basic shelter, operating an accommodation center also implies, according to the municipal unit for refugee administration, assisting the refugees with their arrival in Frankfurt and "cooperating with volunteering structures and networking with the respective neighborhood" (Stabsstelle Flüchtlingsmanagement 2019a, author's translation). Usually, there is one staff, the so-called "volunteering coordinator", who is assigned to managing the contact between the accommodation center and volunteers and neighbors. The municipal unit itself also aims to support and coordinate the activities of different social bodies and actors in the neighborhoods that are adjacent to the accommodation centers (Stabsstelle Flüchtlingsmanagement 2019b).

Thus, neighborhood-based volunteering is an important factor for the municipal reception policy. The neighbors are needed to fill the gaps in social assistance for refugees. Nevertheless, the logic of accommodation mismatches the ideal and practical efforts of neighborhood-based refugee reception, especially in those neighborhoods, which host emergency and provisional accommodation centers (currently the dominant form of residence for refugees in Frankfurt), as I am going to elaborate in the following section. This mismatch is further aggravated by spatially fetishizing the neighborhood as the social space of inclusion. It ignores the living reality of the refugees and leads to frustration for all of the stakeholders involved-volunteers, refugees, and the operators of the accommodation centers alike. The municipality in this way produces a political paradox: encouraging neighborhood activities for migrant inclusion that are destined to fail given the dominant political practice of refugee reception.

\section{Welcome to Rödelheim: Neighborhood, Accommodation Centers, and Volunteering for Inclusion}

The city of Frankfurt consists of 46 official neighborhoods (Figure 2). One of these is Frankfurt-Rödelheim, which has formed part of the city of Frankfurt since 1910 and included 18,865 inhabitants in 2018 (Bürgeramt 2019, p. 2). With one-third (33.7\%) of the inhabitants comprising foreigners, and assuming an analogous number of people with an immigrant background, Rödelheim 
slightly exceeds Frankfurt's average of residents with some kind of migration history. The neighborhood has a vital civil society landscape and it hosts many cultural activities. As part of the "Frankfurt Active Neighborhood"-program, Rödelheim's western district has a neighborhood office that is run by a district manager from a Christian welfare organization and funded by the city of Frankfurt. If you enter Rödelheim by one of the bigger access roads, you will be welcomed to "Rödelheim-Neighborhood against racism" (Figure 3).

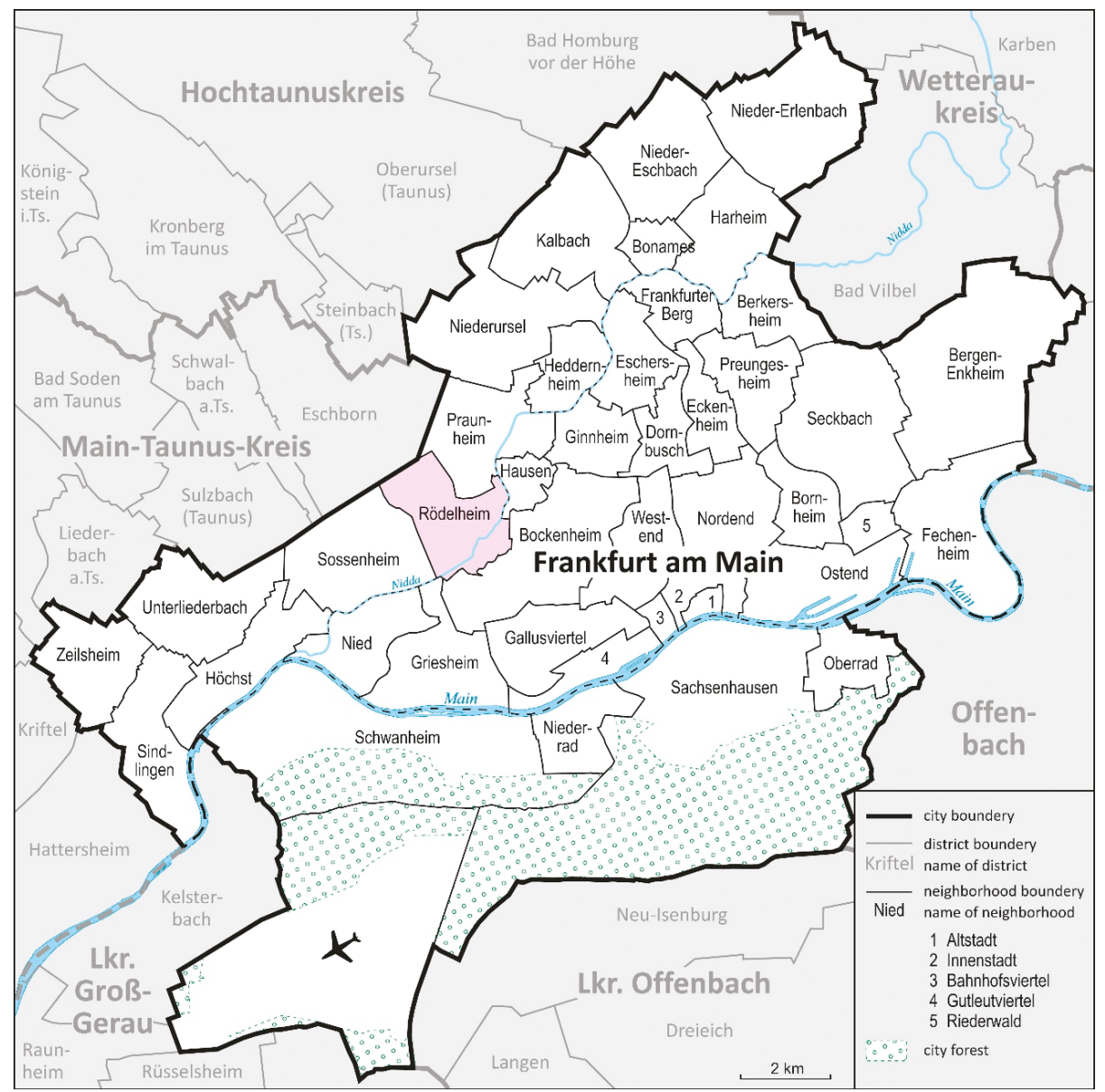

Figure 2. Map of the location of Rödelheim within Frankfurt (created by Department of Human Geography, Goethe-University Frankfurt, data provided by Stadt Frankfurt am Main 2019).

Thus, at first glance, Rödelheim seems to be an ideal place for housing refugees. In fact, Rödelheim accommodates an above-average percentage of the refugees living in Frankfurt. In addition to a series of shared apartments for unaccompanied refugee minors, most of the refugees in Rödelheim live in one of the three bigger accommodation centers. There is a converted office building that was inaugurated in summer 2016 with about 500 spots occupied in August 2018, a former hotel that was converted into an accommodation center in October 2015 for about 130 refugees, and a rebuilt factory site that was inaugurated in 2017 with about 230 spots occupied in September 2018. 


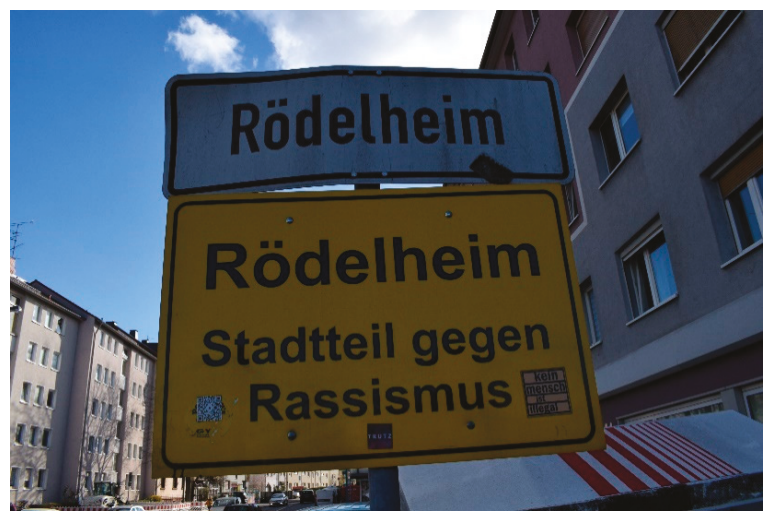

Figure 3. Neighborhood sign saying "Rödelheim—Neighborhood against racism" (photo credit: author).

In the summer of 2015, a neighborhood-based volunteer network for refugee reception emerged before the city of Frankfurt opened the first accommodation center in Rödelheim. Today, "Welcome to Rödelheim" is a prize-winning network of about 40 active and 60 passive members that organize help and social and cultural activities for refugees in the neighborhood. This includes German classes, homework tutoring, lending and repairing bicycles, excursions into the city and its surrounding, individual support with paperwork and administrative authorities, as well as joint leisure activities, like cooking and gardening. Through these neighborhood activities, the welcome initiative provides contact opportunities for what they call "old" and "new" Rödelheim-residents, and it strives to create a welcoming environment in the neighborhood. As the initiative states on its website, it aims to "make a contribution to a successful arrival in the neighborhood" and to support refugees "in order to facilitate their arrival in Rödelheim's neighborhood society" (Willkommen in Rödelheim 2019).

Some of the refugees make considerable use of the support that is offered by the volunteers. German classes, homework tutoring, and the bicycle repair shop are frequently attended by core groups of refugees that are accommodated in Rödelheim-very often the same refugees participate in all of these activities or at least several ones. Additionally, there are refugees who only make sporadic use of the support offered. Personal assistance is sought-after by most refugees getting in touch with the initiative, but difficult to sufficiently provide by the volunteers, while leisure activities for community building, like cooking or attending festivals, are less frequented.

Like other welcome initiatives, "Welcome to Rödelheim" has not gained active participation and representation of refugees within its organizational bodies, like the monthly plenum or the particular groups that are dedicated to the various activities. This may be partly due to hierarchical concepts and the practices of helping as identified above as "new dispositif of helping". It surely roots to a certain extent in the backbreaking decision-making processes that have also alienated many volunteers from the organizational structure of the initiative. Nevertheless, according to various stakeholders, such as volunteers, the municipality, the welfare organizations operating the accommodation centers, and the district manager, the main challenge facing refugee reception in Rödelheim is that only few refugees that are accommodated in Rödelheim even find their way into the neighborhood. The inclusion of refugees into community activities and the contact between refugees and neighbors remains below these stakeholders' expectations.

The reasons for the disconnect between neighborhood-based offerings for refugee reception and refugee attendance are manifold, and they are rooted in various gaps between refugee needs and the existing support. Nevertheless, the most striking mismatch is the one between refugee accommodation and the ideal of neighborhood-based refugee inclusion. As already stated in the introduction, there is a fundamental spatial discrepancy between the demand to integrate and the provided conditions that roots in the national system of dispersion and is reproduced in the local accommodation policy. 
Rödelheim hosts three big accommodation centers, as already outlined above. There are few everyday contact points between refugees and other residents of Rödelheim due to the isolated location of the accommodation centers. Moreover, the neighborhood-based volunteers also have difficulty getting in touch with the refugees and trying to build bridges between the accommodation centers and the neighborhood (Figure 4).

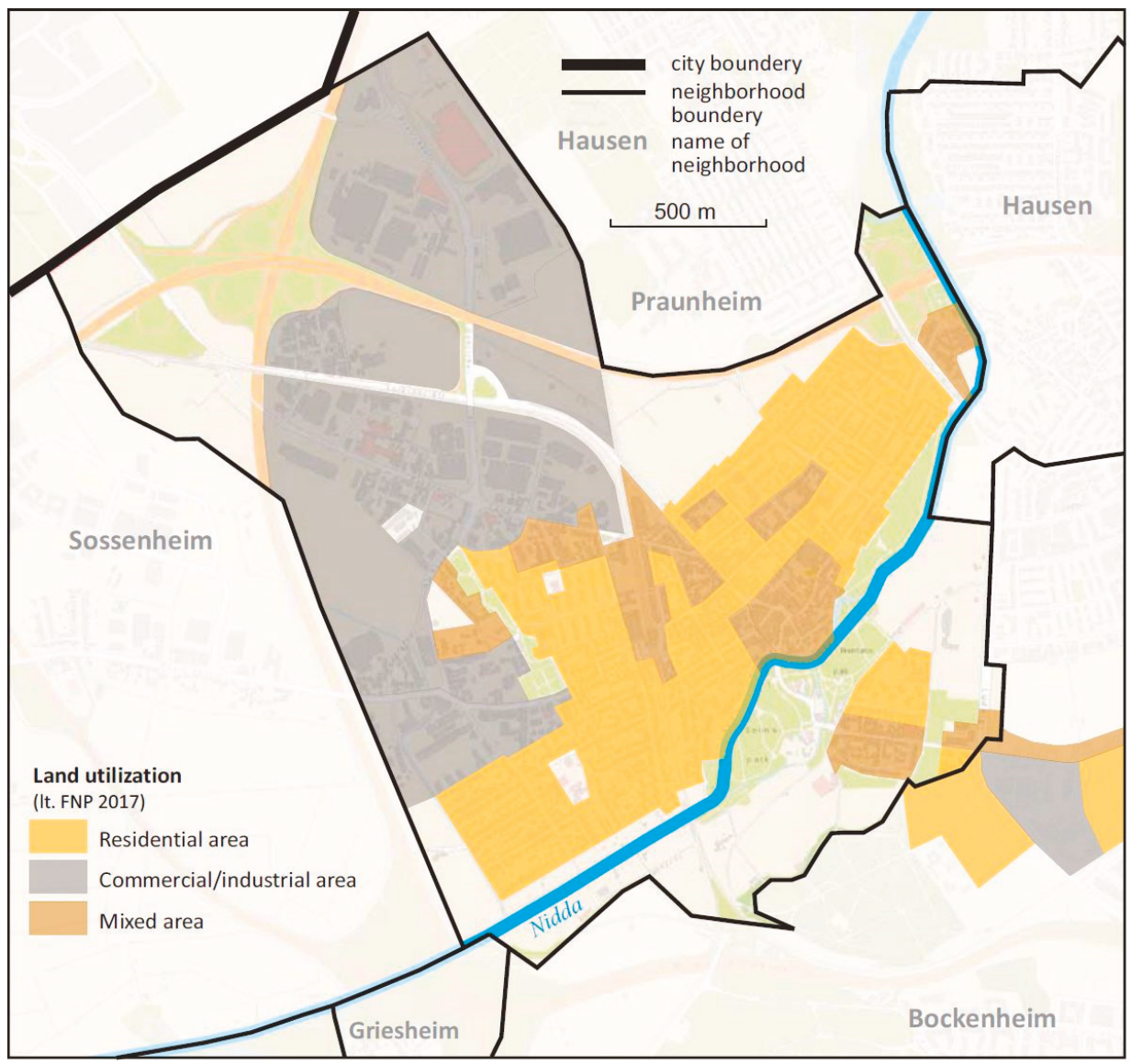

Figure 4. Map of industrial and residential areas in Rödelheim ${ }^{1}$ (created by Department of Human Geography, Goethe-University Frankfurt, data provided by Stadt Frankfurt am Main 2019).

The first center, a former office building and the biggest accommodation center in Rödelheim, is located on the periphery of Rödelheim, adjacent to a major road, and an industrial zone flanks it. In fact, the post address of the building belongs to a different neighborhood, Bockenheim, but most of the stakeholders involved, even municipal authorities, share the assumption that it formally belongs to Rödelheim. However, the building does not form part of the social fabric of either neighborhood. As the district manager said to me, it is "some kind of no man's land". The bus runs right in front

1 As there have been abundant racist assaults on refugee accommodation centers in Germany in the past, there is a tacit agreement not to map accommodation centers. Therefore, I am not going to map the accommodation centers in Rödelheim or include pictures of them. For the same reason, the city of Frankfurt does not publish postal addresses of accommodation centers although neighbors get informed and local media report in detail when new centers are planned. 
of the house, so refugees living in this accommodation center usually will not pass through adjacent neighborhoods when going to work, to German class, or shopping. Contact points with neighbors are almost non-existent, and social and economic involvement in the neighborhoods remains very low. Many of the refugee residents, who do not have courses or chores to accomplish outside of the center, stay in the building and its premises the whole day. The building provides some space for communal activities. There is a central entrance with a check-in desk and the visitors are only allowed to enter if they have an appointment and they are registered with their identity card. Therefore, the only avenue is participating in a form of official volunteering activity within the center if the neighbors want to make even initial contact with refugee residents. However, the neighborhood-based volunteers do not serve this center, as the area does not form part of their everyday practices. They relay information regarding their activities to the volunteering coordinator of the center, but they do not usually visit the center to pick people up for activities, nor do they offer activities there. As my co-volunteers and the district manager told me, it is simply off their personal map. Consequently, the volunteering coordinator in the center explained to me that it is impossible to find volunteer support from within the neighborhood. Therefore, she recruits volunteers from all over the city who offer their assistance regardless of place. These volunteers may be of great help to the refugees, but they do not serve as a channel for further contact into the neighborhood, as they live somewhere else. This does not mean that the refugees housed in the center never show up in communal activities in the neighborhood of Rödelheim. Some attend German classes that are offered by the network, for example, but those participating are few and far between. Furthermore, attending a German class does not lead to other types of involvement in community activities in the neighborhood. Thus, the biggest of the three accommodation centers is essentially disconnected from the neighborhood and the place-based efforts for refugee reception due to its remote location and its restricted access.

Many of the aforementioned challenges also apply to the second accommodation center, the former hotel. Its location is less remote, but access is very restricted, and, in addition, there is no common room for volunteering activities. However, the volunteering group initially put forth great effort to get in touch with the people living there, as the former hotel was the first of the three accommodation centers in Rödelheim. In contrast to the first center, volunteers stop by to pick up potential participants for special activities, like field trips or other outings. However, as in the case of the first accommodation center, contact between refugees and volunteers relies on individuals' efforts. Volunteers reported to me that the hostile environment in the reception was an additional stumbling block in forging relationships with refugee residents. Moreover, with the opening of a third center in 2017, volunteers split their efforts between the former hotel and the new center. Therefore, over time, the former hotel came to be partially left out of the volunteers' considerations. In almost very monthly meeting, as well as in my group interviews, eventually someone would say: "Let's not forget about the people living in the former hotel". Concurrently, neighborhood-based activities like excursions into the city or cooking together became less relevant to the refugees accommodated in the former hotel. Most of them have already been living in Germany for several years and they face different challenges than those first arriving into a city. They may be working or looking for work, searching for available apartments, or they may have to arrange schooling for their children. Thus, for less-recent arrivals, the most important support would be one-on-one contact with a volunteer who could assist them in their specific needs. A former social worker, for example, helps to communicate with authorities, potential employers, and the like. Two former teachers individually support children with learning difficulties, and other volunteers accompany refugees looking for assistance in their daily struggles with the German asylum system. As several refugees have told me, this kind of assistance is very helpful to them and, while some efforts are embedded in the neighborhood-based networking of the volunteering initiative, it works independently from neighborhood-based community activities. Beyond the individual refugee-volunteer relationships, these efforts do not lead to a broader inclusion of refugees into neighborhood activities. More assistance being offered by neighbors nearby would be 
beneficial, especially by accompanying refugees in their everyday lives. Nevertheless, this does not equal or lead to the integration of refugees into the neighborhood.

The third accommodation center can be characterized as an outlier to the other centers. It occupies industrial premises, similarly to the first accommodation center. However, it is located much closer to a residential area than the former office building and it is surrounded by an excellent commercial infrastructure. The city reconstructed this old factory site, at great financial cost, and the new center was inaugurated in 2016. Of the three centers in Rödelheim, it is the one with the lowest living standard. It includes accommodation units in a hallway with only curtains separating the individual living spaces, aside from a women's house with fully-equipped shared apartments and barracks with crowded rooms. In sharp contrast to the most basic living conditions, the center has well-outfitted common rooms and space for volunteering activities. There are two well-equipped classrooms, a women's room, and the so-called "neighborhood café". The volunteers are free to offer enrichment activities in all of these rooms. In fact, by now, a considerable part of the activities conducted by the neighborhood-based volunteering network takes place on the premises. However, access to this accommodation center is restricted, as in the case of the two other centers. The compound is fenced off and an invitation and identity card are required to enter the premises.

Nevertheless, in comparison to the other two centers, there are far more points of contact between refugees and the neighbors. First of all, there are abundant regular volunteering activities where neighborhood-based volunteers and refugees meet, for example, through homework tutoring, literacy courses, a sewing get-together, a bicycle repair shop, and more. Additionally, there are occasional cultural activities open to the neighborhood, though usually these activities do not draw in outside residents. The bicycle repair shop stands out from the volunteering activities, as it is located at the border of the premises and open to the street. In this way, it is an interface between refugees and other neighborhood residents. Not only do volunteers and refugees meet here, but other neighbors also use this shop if they need help with their bicycles. During my field research there was a period when the bicycle repair shop developed into some kind of informal passage into the accommodation center, because, for a short time during the summer, the fence separating the shop from the premises was open when the shop was open. The center's residents drew on it as alternative entrance and children used it in order to play inside and outside the premises. Nevertheless, after a short period, the operators closed this passage in accordance with the city's rules for security.

Last, but not least, there is the so-called "neighborhood café". This neighborhood café is a telling example of what could have been and what opportunities may still arise from refugee-neighbor interactions. It originated from the planning phase of the accommodation center when the district management promoted the establishment of a common space on the premises or close to it, which would be open to the neighborhood. As the district manager reported to me, the idea of the café was some kind of communal center or social meeting point where people could have space for community activities of various kinds-not only for refugee reception. Due to the scarcity of spaces that are designated for this kind of activity in Rödelheim (and Frankfurt more generally), this would have been an innovative opportunity to facilitate conversation and exchange for people from different walks of life and bringing the neighborhood to the accommodation center. Yet, the future operators had different plans. Instead of a community space that is open to the neighborhood, the welfare organization operating the center opened the neighborhood café as an enclosed room on the premises, which was only accessible through the restrictive gate and complicated entrance procedures that are outlined above. As a result, exclusively, the welfare organization itself used the room until the volunteering coordinator motivated some of the neighborhood-based volunteers to utilize the café for homework tutoring. Later, the operator installed the information desk for the center's residents in the same room. This way, it developed into a meeting point between volunteers and people living in the center. Though some volunteers and refugees attending the regular homework tutoring class complain about disturbances and noise in the cafe, they also appreciate the open space that allows for 
spontaneous contact and interaction aside from the homework tutoring, as volunteers and refugee also meet by incident and engage in small talk and informal conversation.

Thus, the case of the third center shows how refugee-neighborhood interaction comes about if there is enough space for communal activities, cooperation between the organization operating the center and the volunteers, and — as a result — a physical and symbolic opening of the accommodation center. Volunteers who spend much time here experience the center as relatively open and welcoming, referring to it as a "little village", though many restrictions remain and the relationship to the operators is therefore unavoidably fraught with conflict. However, this interaction in the accommodation center has little to do with the ideal of refugee inclusion into the neighborhood. One could even say that it is the other way around. The volunteers get integrated into the accommodation center. They develop relationships there, a routine, and even a sense of place (Massey 1991). They have to cross borders that are established through municipal rules and implemented by the welfare organizations running the accommodation centers.

However, this inclusion of volunteers into the social space of the accommodation center is accompanied by a constant problematization of the lack of integration of refugees into the neighborhood by different stakeholders. This leads neighborhood volunteers questioning their achievements. One of my co-volunteers explained to me that, on the one hand, he sees his volunteering as a simple service to people in need and he enjoys forming relationships with refugees. On the other hand, it frustrates him that refugees do not participate in broader neighborhood activities. "Getting in touch" is the reason that is most mentioned by the volunteers for their commitment to volunteering, but the question as to where volunteers and refugees should meet is highly controversial. The rising number of activities in the accommodation center, for example, is a constant source of debate within the volunteering network, especially with regard to the self-conception as network volunteering for the integration of the newcomers into the neighborhood. As one participant once put it in the monthly plenary meeting, "our name is 'Welcome to Rödelheim', not 'Welcome to the accommodation center'!"

Right before the opening of the first aforementioned accommodation center, the former office building, a local newspaper reported on the story with the striking subtitle: "Solidarity is strong, but the site does not seem optimal for the integration of refugees" (Hubert 2016, author's translation). The newspaper also quoted a member of "Welcome to Rödelheim", which criticized the remote location and the fact that people living there would have to rely on public transport for their daily duties and would not be part of the social fabric of the neighborhood. The corresponding department of the municipality was well aware of this fact, but, in reply, called on churches and initiatives to "step up to the cause of helping people" (ibid.). In this way, the municipality under-emphasizes the challenges that arise from the geographic and social isolation of the accommodation centers and it creates unaccomplishable tasks for the volunteers. How are neighbors to step up, if even initial contact is made so difficult? How is volunteering to connect spatially disconnected accommodation centers to the social fabric of the neighborhoods? The constant efforts to alleviate this situation are time-consuming and tiring for all of the stakeholders involved. Social workers and volunteers have to remind and organize people living at the accommodation centers constantly about volunteer activities, according to the volunteers and the volunteering coordinator of the third accommodation center. Aside from the additional threat of deportations, which has been a minor issue in this specific case, the repeated relocation of refugees within Frankfurt adds up to this situation. Thus, the ideal of welcoming "new neighbors" does not only miss the fact that refugees do not live in the neighborhood that they will likely settle, but that they will not even stay within the same neighborhood during the assessment process. This way, the above-mentioned discrepancy between the municipalities' overall progressive immigration agenda and the lack of effective measures for inclusion is being reproduced in the subarea of refugee reception. However, instead of introducing more effective policies, the lack of political consistency is passed onto civil society, which is left with the time-consuming, work-intensive, and frustrating task of neighborhood integration that is almost doomed to fail. 


\section{Refugee Reception as Neighborhood-Based Process?}

Collective accommodation centers, like the ones that are portrayed here, residentially separate newcomers from the rest of society. Thereby, they contradict as much the rise of post-migrant societies with "super diverse" cities (Vertovec 2007) as the paradigm of migrant reception through community activities at the local level (Schnur et al. 2013). The spatial separation of refugees from society through accommodation centers thereby reinforces the dominant asylum system that prioritizes delineation over inclusion. However, the dominant system of dispersion cannot be combated by pressuring volunteers and refugees to achieve integration at the local level.

Political elites have not considered Germany as a country of immigrants until the 21st century, although it has a long tradition of immigration and migrant communities. Now that this is changing, Germany has already developed from a country of immigrants into a "postmigrant" society (Foroutan 2016). We are dealing with a societal configuration that constantly shifts through migration and movement in cities like Frankfurt. While the neighborhood made its way to official national integration policy, the actual demographic development of bigger West German cities calls into question the concept of immigrant integration into a somehow pre-configured society. Thus, instead of "integration", which has developed into the leitmotif of conservative debates regarding the responsibilities of immigrants, the latest progressive political and academic discourses evolve around the terms "participation" and "inclusion" to highlight racial exclusions and the need to remedy them in order to develop an open and inclusive society (Ataç and Rosenberger 2013; Georgi 2015; Scherr and Inan 2018). Consequently, debates concerning "integration" and "neighborhood management" have also developed towards a better understanding of the complexity of post-migrant societies and the need to open up neighborhoods for diversity (e.g., Beer 2013; Schnur 2018). However, the recent arrival of greater numbers of refugees has prompted a politically-embraced revival of neighborhood-based migrant reception, which tends to fetishize the neighborhood as social space of integration and thereby runs the risk of reproducing outdated concepts of immigrant's integration into pre-existing societies at a smaller scale.

The refugees that I have spoken to are not looking for inclusion into the neighborhood. They are looking for support. Asylum-seekers lack the intensive personal assistance necessary in order to navigate through the German asylum system and the multiple political, economic, social, and cultural barriers to inclusion. This kind of assistance does not require place-based integration. Yet, the volunteer capacity to provide refugees with this kind of assistance is scarce, and, indeed, many helpers prefer volunteering in low-threshold collective activities in their neighborhoods. These activities nonetheless do serve a purpose, as they place volunteers and refugee in contact with one another and may lead to more personalized assistance and closer relationships. In this way, one kind of assistance may serve as a bridge, or gateway, to other forms of support. In the case of Rödelheim, neighbors who engage in some kind of community activity for refugee reception, and thereby form relationships with individual refugees, provide much of the assistance that refugees receive. Thus, neighborhood-based activities fulfill a vital role for refugees in finding support. Nevertheless, they should not be fetishized as principal gateways to integration. In many cases, participating in neighborhood activities places additional burden on refugees' daily lives through the time and effort required.

Thus, the overall asylum system and everyday reality of refugees has to improve, instead of focusing on neighborhood integration. Especially, as this paper highlights, the national system of involuntary refugee distribution and long lasting residence obligation, as well as the local practice of relocating refugees to spatially segregated accommodation centers, need to be reconsidered as soon as possible. This issue is also connected to housing policies in Germany, in general, and municipal housing policies of larger German cities, in particular, where a shortage of affordable housing is increasingly causing contention and political conflict (Schönig et al. 2017; Werner et al. 2018). However, there is still much that can be done on the local level, even within the existing institutional structure and housing crisis. For example, the municipal unit for refugee administration (tellingly lately renamed as "municipal unit for accommodation management and refugees") is working on new concepts to 
improve the living spaces for refugees. Currently, they are building a fourth accommodation center in Rödelheim, which will provide shelter to 160 refugees and 120 university students. This kind of mixed-use housing has already been successfully tested in Munich and it seems more promising towards goals of living diversity than the current refugee housing. With regard to the existing accommodation centers, every effort should be made to make them more accessible for volunteers by providing meeting space, supporting the volunteers, and making visitor access as easy as possible, without, of course, putting the safety of refugees at risk. Moreover, the municipality has to invest in more professional third-party assistance for refugees. Instead of fetishizing the neighborhood as social space of inclusion and demanding integration, the better way for refugee reception might be to meet refugees where they are and providing them with the kind of support that they are asking for.

Funding: This research was funded by the German Research Foundation, grant number PU 209/12-1.

Acknowledgments: I would like to thank Robert Pütz, Mathias Rodatz \& Jan Kordes for their valuable comments on the manuscript, Afra Höck for her helpful assistance, and the anonymous reviewers for their thoughtful feedback.

Conflicts of Interest: The author declares no conflict of interest. The founding sponsors had no role in the design of the study; in the collection, analyses, or interpretation of data; in the writing of the manuscript, and in the decision to publish the results.

\section{References}

Ataç, Ilker, and Sieglinde Rosenberger. 2013. Inklusion/Exklusion-Ein relationales Konzept der Migrationsforschung. In Politik der Inklusion und Exklusion. Edited by Ilker Ataç and Sieglinde Rosenberger. Göttingen: V\&R unipress, pp. 35-52.

BAMF. 2019. Aktuelle Zahlen zu Asyl. Nürnberg: Bundesamt für Migration und Flüchtlinge.

Beer, Ingeborg. 2013. Quartiersentwicklung als Diversitäts- und Teilhabestrategie. Zwischen traditionellen Integrationsdiskursen und gelebten Migrationsrealitäten. In Migrationsort Quartier: Zwischen Segregation, Integration und Interkultur. Edited by Olaf Schnur, Philipp Zakrzewski and Matthias Drilling. Wiesbaden: Springer VS, pp. 41-54.

Bendel, Petra, and Andrea Borkowski. 2016. Entwicklung der Integrationspolitik. In Einwanderungsgesellschaft Deutschland: Entwicklung und Stand der Integration. Edited by Heinz Ulrich Brinkmann and Martina Sauer. Wiesbaden: Springer VS, pp. 99-116.

Blank, Martina. 2019. Räume des Asyls: Deutschlernen und die Rolle von Raum für die lokale Aushandlung von Asylregimen. In Konfliktfeld Fluchtmigration. Historische und Ethnographische Perspektiven. Edited by Reinhard Johler and Jan Lange. Bielefeld: Transcript, Forthcoming.

Browne, Kath, Leela Bakshi, and Arthur Law. 2010. Positionalities: It's not About Them and Us, It's About Us. In The SAGE Handbook of Social Geographies. Edited by Susan J. Smith, Rachel Pain, Sallie A. Marston and John Paul Jones III. London: Sage Publications, pp. 586-605.

Bryant, Antony, and Kathy Charmaz, eds. 2007. The SAGE Handbook of Grounded Theory. Los Angeles: Sage.

Bundesregierung. 2007. Der Nationale Integrationsplan: Neue Wege-Neue Chancen. Berlin: Presse- und Informationsamt der Bundesregierung/Die Beauftragte der Bundesregierung für Migration, Flüchtlinge und Integration.

Bürgeramt, Statistik und Wahlen. 2018. Statistisches Jahrbuch Frankfurt am Main 2018: Bevölkerung. Frankfurt am Main: Magistrat der Stadt Frankfurt am Main, Bürgeramt, Statistik und Wahlen.

Bürgeramt, Statistik und Wahlen. 2019. Einwohnerinnen und Einwohner am 31.12.2018—Bevölkerungswachstum hält weiter an. Frankfurt am Main: Magistrat der Stadt Frankfurt am Main, Bürgeramt, Statistik und Wahlen.

Clarke, Adele E. 2005. Situational Analysis: Grounded Theory after the Postmodern Turn. Thousand Oaks, London and New Delhi: Sage Publications.

Fleischmann, Larissa, and Elias Steinhilper. 2017. The Myth of Apolitical Volunteering for Refugees: German Welcome Culture and a New Dispositif of Helping. Social Inclusion 5: 17-27. [CrossRef]

Foroutan, Naika. 2016. Postmigrantische Gesellschaften. In Einwanderungsgesellschaft Deutschland: Entwicklung und Stand der Integration. Edited by Heinz Ulrich Brinkmann and Martina Sauer. Wiesbaden: Springer VS, pp. 227-54. 
Frankfurter Stadtverordnetenversammlung. 2017. Kommunale Standards und Rahmenbedingungen für die Unterbringung und Integration von Flüchtlingen in Frankfurt am Main: Beschlossen von der Stadtverordnetenversammlung am 4. Mai 2017. Frankfurt am Main: Magistrat der Stadt Frankfurt am Main.

Georgi, Viola B. 2015. Integration, Diversity, Inklusion: Anmerkungen zu aktuellen Debatten in der deutschen Migrationsgesellschaft. DIE Zeitschrift für Erwachsenenbildung 2: 25-27.

Gesemann, Frank, and Roland Roth, eds. 2018. Handbuch Lokale Integrationspolitik. Wiesbaden: Springer Fachmedien Wiesbaden.

Girtler, Roland. 2001. Methoden der Feldforschung. Wien and Köln/Weimar: Böhlau Verlag/UTB.

Hamann, Ulrike, Serhat Karakayali, Leif Jannis Höfler, Laura Lambert, and Leoni Meyer. 2017. Pionierinnen der Willkommensgesellschaft. Strukturen und Motive des Engagements für Geflüchtete. Berlin: Berliner Institut für empirische Integrations- und Migrationsforschung, Humboldt-Universität zu Berlin.

Hess, Sabine, and Vassilis S. Tsianos. 2010. Ethnographische Grenzregimeanalyse: Eine Methodologie der Autonomie der Migration. In Grenzregime: Diskurse, Praktiken, Institutionen in Europa. Edited by Sabine Hess and Bernd Kasparek. Hamburg: Assoziation A, pp. 243-64.

Hess, Sabine, Bernd Kasparek, Stefanie Kron, Mathias Rodatz, Maria Schwertl, and Simon Sontowski. 2017. Der Lange Sommer der Migration. Krise, Rekonstitution und ungewisse Zukunft des europäischen Grenzregimes. In Der lange Sommer der Migration: Grenzregime III. Edited by Sabine Hess, Bernd Kasparek, Stefanie Kron, Mathias Rodatz, Maria Schwertl and Simon Sontowski. Berlin/Hamburg: Assoziation A, pp. 6-24.

Hinger, Sophie, Philipp Schäfer, and Andreas Pott. 2016. The Local Production of Asylum. Journal of Refugee Studies 29: 440-63. [CrossRef]

Hubert, Denis. 2016. Zweifel an Lage von Flüchtlingsunterkunft. Frankfurter Rundschau Online. Available online: https://www.fr.de/frankfurt/deutsches-rotes-kreuz-org26752/zweifel-lage-fluechtlingsunterkunft11121241.html (accessed on 2 April 2019).

Hugman, Richard, Eileen Pittaway, and Linda Bartolomei. 2011. When ‘Do No Harm' Is Not Enough: The Ethics of Research with Refugees and Other Vulnerable Groups. British Journal of Social Work 41: 1271-87. [CrossRef]

Karakayali, Serhat, and Olaf Kleist. 2016. Strukturen und Motive der Ehrenamtlichen Flüchtlingsarbeit (EFA) in Deutschland, 2. Forschungsbericht: Ergebnisse einer Explorativen Umfrage vom November/Dezember 2015. Berlin: Berliner Institut für empirische Integrations- und Migrationsforschung Humboldt-Universität zu Berlin.

Kuckartz, Udo. 2016. Qualitative Inhaltsanalyse. Methoden, Praxis, Computerunterstützung. Weinheim and Basel: Beltz. Massey, Doreen. 1991. A global sense of place. Marxism Today, June 24-29.

Müller, Martin. 2013. Mittendrin statt nur dabei: Ethnographie als Methodologie in der Humangeographie. Geographica Helvetica 67: 179-84. [CrossRef]

Pütz, Robert, and Mathias Rodatz. 2013. Kommunale Integrations- und Vielfaltskonzepte im Neoliberalismus: Zur strategischen Steuerung von Integration in deutschen Großstädten. Geographische Zeitschrift 101: 166-83.

Radtke, Frank-Olaf. 2003. Multiculturalism in Germany: Local management of immigrants social Inclusion. International Journal on Multicultural Societies 5: 55-76.

Rodatz, Mathias. 2014. Migration ist in dieser Stadt eine Tatsache: Urban politics of citizenship in der neoliberalen Stadt. Sub urban 2: 35-58.

Ronneberger, Klaus, and Vassilis S. Tsianos. 2009. Panische Räume. Das Ghetto und die »Parallelgesellschaft«. In No integration?! Kulturwissenschaftliche Beiträge zur Integrationsdebatte in Europa. Edited by Sabine Hess, Jana Binder and Johannes Moser. Bielefeld: Transcript, pp. 137-52.

Rose, Gillian. 1997. Situating knowledges: Positionality, reflexivities and other tactics. Progress in Human Geography 21: 305-20. [CrossRef]

Schammann, Hannes. 2015. Wenn Variationen den Alltag bestimmen. Unterschiede lokaler Politikgestaltung in der Leistungsgewährung für Asylsuchende. Zeitschrift für Vergleichende Politikwissenschaft 9: 161-82. [CrossRef]

Schammann, Hannes, and Boris Kühn. 2016. Kommunale Flüchtlingspolitik in Deutschland. Bonn: Friedrich-Ebert-Stiftung. Scherr, Albert, and Çiğdem Inan. 2018. Leitbilder in der politischen Debatte: Integration, Multikulturalismus und Diversity. In Handbuch Lokale Integrationspolitik. Edited by Frank Gesemann and Roland Roth. Wiesbaden: Springer Fachmedien Wiesbaden, pp. 201-26.

Schnur, Olaf. 2018. Quartiersentwicklung für alle? In Handbuch Lokale Integrationspolitik. Edited by Frank Gesemann and Roland Roth. Wiesbaden: Springer Fachmedien Wiesbaden, pp. 373-91. 
Schnur, Olaf, Philipp Zakrzewski, and Matthias Drilling, eds. 2013. Migrationsort Quartier. Zwischen Segregation, Integration und Interkultur. Wiesbaden: Springer VS.

Schönig, Barbara, Justin Kadi, and Sebastian Schipper, eds. 2017. Wohnraum für alle?! Perspektiven auf Planung, Politik und Architektur. Bielefeld: transcript Verlag.

Stabsstelle Flüchtlingsmanagement. 2019a. Aktuelle Zahlen. Available online: https:/fluechtlinge-frankfurt.de/ aktuelle-zahlen/ (accessed on 13 March 2019).

Stabsstelle Flüchtlingsmanagement. 2019b. Unterbringung von Flüchtlingen: Integration der Flüchtlinge in den Stadtteilen. Available online: https://fluechtlinge-frankfurt.de/unterbringung-von-fluechtlingen/\#toggle-id-6 (accessed on 13 March 2019).

Stadt Frankfurt am Main. 2011. Vielfalt bewegt Frankfurt: Integrations- und Diversitätskonzept für die Stadt, Politik und Verwaltung. Frankfurt am Main: Magistrat der Stadt Frankfurt am Main.

Vertovec, Steven. 2007. Super-diversity and its implications. Ethnic and Racial Studies 30: 1024-54. [CrossRef]

Welz, Gisela. 1998. Wie verwaltet man die kulturelle Vielfalt einer Weltstadt? Das Frankfurter Amt für multikulturelle Angelegenheiten. In Frankfurt am Main: Ein kulturanthropologischer Stadtführer. Edited by Ina-Maria Greverus, Johannes Moser, Heinz Schilling and Gisela Welz. Frankfurt am Main: Goethe-Universität Frankfurt, Institut für Kulturanthropologie und Europäische Ethnologie, pp. 33-48.

Werner, Franziska, Annegret Haase, Nona Renner, Dieter Rink, Malena Rottwinkel, and Anika Schmidt. 2018. The Local Governance of Arrival in Leipzig: Housing of Asylum-Seeking Persons as a Contested Field. Urban Planning 3: 116-28. [CrossRef]

Willkommen in Rödelheim. 2019. Wer Sind WiR? Available online: http://willkommen-in-roedelheim.de/wersind-w-i-r (accessed on 1 May 2019).

Yildiz, Erol. 2014. Medialer Umgang mit Migration: Vom Urbanen Ghettodiskurs zur Alltagspraxis. Berlin: Forum Wohnen und Stadtentwicklung: Verbandsorgan des vhw-Bundesverband für Wohnen und Stadtentwicklung e.V.

(C) 2019 by the author. Licensee MDPI, Basel, Switzerland. This article is an open access article distributed under the terms and conditions of the Creative Commons Attribution (CC BY) license (http://creativecommons.org/licenses/by/4.0/). 


\title{
Article \\ Integration in the Shadow of Austerity-Refugees in Newcastle upon Tyne
}

\author{
Matthias Flug * and Jason Hussein \\ Hub Drop-in for Asylum Seekers and Refugees, Newcastle NE4 6NX, UK \\ * Correspondence: m.flugg@gmail.com
}

Received: 23 April 2019; Accepted: 2 July 2019; Published: 8 July 2019

\begin{abstract}
Newcastle upon Tyne, a post-industrial city in the North East of England, has long been committed to hosting refugees. Although the city has suffered drastic cuts in government funding and faces high levels of deprivation, Newcastle declared itself a city of sanctuary and participates in several dispersal schemes for asylum seekers and refugees. This paper shows how political support as well as the self-motivating ambition to be a city of sanctuary are driving forces behind the city's commitment to hosting refugees. This study then proceeds to explore the integration experiences of refugees in Newcastle, with a focus on housing, employment and the relations between refugees and local residents. While an overall positive picture emerges across these areas, language barriers, the refusal to accept refugees' previous qualifications and experiences of racism remain major obstacles to integration. Moreover, the gulf in funding and support between resettled refugees and former asylum seekers greatly aggravates the latter's access to housing and employment and contributes to a lower feeling of safety among this group.
\end{abstract}

Keywords: integration; refugees; austerity; community relations; employment; local politics; North East of England

\section{Introduction}

This paper explores the integration process of refugees in Newcastle upon Tyne (Newcastle), a post-industrial city in the North East of England. Having faced large-scale deindustrialisation and extensive government funding cuts, the city struggles with high poverty and unemployment levels. Yet, despite ranking among the most deprived $20 \%$ of local authorities in England, Newcastle has long been hosting refugees (Casla et al. 2018, p. 3). Newcastle City Council (NCC) was among the first local authorities to take part in the national dispersal scheme for asylum seekers introduced in 1999. Newcastle also participates in the Vulnerable Person Resettlement Scheme (VPRS), which predominantly focuses on Syrian refugees and, in 2014, NCC passed a motion in favour of becoming an official City of Sanctuary.

Against this background of welcome and economic deprivation, this research will explore how refugees have adapted to the city, especially with regards to employment and housing. We will also examine the attitudes and interactions between local residents and refugees, as well as the role of refugees' own communities in helping newly arrived individuals settle in Newcastle. In the process, language skills, age, and experiences of racism will be identified as key factors that either obstruct or facilitate refugees' integration experience. It will further be shown how the gulf in support between resettled refugees and former asylum seekers impacts negatively on the latter's integration process. This discussion will be preceded by two background sections on refugees in the United Kingdom (UK) and in Newcastle in particular. The latter section will offer a few explanations for NCC's commitment to hosting refugees. 


\section{Research Focus and Rationale}

In light of increasing refugee movements around the world, there is an urgent need to better understand the integration experience of refugees in their various host environments. Since 'integration takes place primarily at the local level', empirical studies at the city level are particularly well suited to foster such understanding (Pastore and Ponzo 2016, p. 3). This paper attempts to contribute to these efforts by exploring the integration experience of refugees in Newcastle. The following questions guided our research:

- What are refugees' experiences with accessing and succeeding in employment and housing in Newcastle and what factors facilitated or obstructed their experiences?

- How do refugees and local residents view and interact with each other and what factors play a role in facilitating or obstructing such interaction?

- How does the integration experience differ between resettled refugees and former asylum seekers?

- What accounts for NCC's commitment to participate in the dispersal system and the VPRS?

While several studies have been written on the integration of migrants in the North East of England, very little research exists on the integration of refugees in the city of Newcastle. Moreover, existing studies tend to focus on the integration of refugees into Newcastle's labour market (see: Vickers et al. 2016) and education system (see: Whiteman 2005). Yet, refugees' position in the local housing market and relations between refugees and local residents have not been researched in any great detail. Our paper aims to fill this gap, by analysing qualitative data from refugees, as well as from local residents. Furthermore, unlike existing work on refugee integration in Newcastle, this paper will distinguish and compare between the experiences of resettled refugees and those of former asylum seekers. In what has essentially become a two-tier asylum system, we aim to highlight how each route impacts the integration of refugees at the local level. As such, this research may inform ongoing policy debates on the future of the asylum dispersal system and the VPRS. Lastly, since local government is increasingly recognised as a key actor in the integration of refugees (see: Dekker et al. 2015), this paper will attempt to explain the stance adopted by NCC. As far as the authors are aware, no previous research has explored the role of NCC in the context of refugee integration.

\section{Theoretical Considerations, Method and Limitations}

Integration is a hotly contested term that is used to advance different and at times conflicting policies and agendas. Berry (1997) regards integration as an acculturation strategy by which newcomers seek the interaction with other cultures, while maintaining their own cultural identity. Others have understood integration as a two-way process that also requires a willingness of the host community to adapt and change (Castles et al. 2002). Moreover, Bowskill et al. (2007) pointed out how integrationist rhetoric, despite its emphasis on tolerance and acceptance, often carries assimilationist undertones. In this regard, Mulvey (2010) outlined how, in recent years, policymakers in the UK ceased to frame integration in terms of multiculturalism and increasingly rely on the notion of 'community cohesion'. He shows how usage of the latter term is often accompanied by the implicit assumption that too much diversity is a threat to such cohesion (Mulvey 2010). The burden to reduce diversity is then placed on the newcomers, who are expected to relinquish their culture and values, which are regarded as inferior to those of the host society (Fekete 2008).

Rejecting the conflation of integration and assimilation, Ager and Strang (2008) view integration as a two-way process, as well as a policy goal. The use of the term 'integration' in this paper will be based on their conceptual framework, which identifies the following key domains of integration: '[ ... ] achievement and access across the sectors of employment, housing, education and health; assumptions and practice regarding citizenship and rights; processes of social connection within and between groups in the community; and barriers to such connection, particularly stemming from lack of linguistic and cultural competences and from fear and instability' (Ager and Strang 2008, pp. 184-85). Ager and Strang further emphasise the need for both refugees and the host community to adapt and 
accommodate the other group. However, apart from a 'lack of conflict' and a sense of 'acceptance', their model offers little guidance on how the host community's willingness to accommodate refugees can be measured. Therefore, we will supplement Ager and Strang's framework with Hynie et al.'s (2016) notion of 'community welcome', defined as positive discourse and attitudes toward refugees among the host community. By using Hynie's concept to examine local residents' attitudes toward refugees, we are able to better understand the extent to which the latter are willing to change and to accommodate refugees. Hynie's concept was thus instrumental in shaping our interview questions with local residents, as will be further outlined below.

Ager and Strang's framework is particularly valuable for empirical studies such as this one, as it enables research to identify correlations between objective markers of integration such as employment and housing and underlying factors such as feelings of safety. Yet, the full application of the model is beyond the scope of this paper. Instead, we identified key themes of the model around which to structure our research. Supported by the concept of community welcome, this paper will examine the social relations between refugees and the host communities, including the attitudes that both groups have toward each other. We will also focus on refugees' access to and achievement in work and housing. These themes were selected based on data considerations. Since refugees enjoy health care, education, housing and employment rights equal to UK citizens, public authorities do not compile separate statistics on the particular group of refugees. Therefore, we had to rely on secondary sources to supplement our findings with quantitative data. As housing and employment featured most prominently in previous studies on refugee integration, we selected these themes as our focus areas.

The qualitative data for this paper was collected through semi-structured interviews with 20 local residents, 3 local government employees and 17 refugees (see Table 1). In a process of triangulation, these findings were then supplemented and compared to quantitative data in previous literature, reports and studies on refugee integration. The interviews offer several insights into how the figures and observations of quantitative studies play out in refugees' individual integration experiences at the city level.

Table 1. Interview Sampling Chart.

\begin{tabular}{cc}
\hline Interview Sampling Chart & Category \\
\hline $\mathbf{N}=\mathbf{3}$ Sex $(\mathbf{M}=\mathbf{0}, \mathbf{F}=\mathbf{3})$ & Key Informants \\
3 & Local Government Employees \\
\hline $\mathbf{N}=\mathbf{1 7}(\mathbf{M}=\mathbf{1 4}, \mathbf{F}=\mathbf{3})$ & Refugees \\
9 & Syrian \\
2 & Sudanese \\
1 & Libyan \\
1 & Ugandan \\
1 & Iranian \\
1 & Eritrean \\
1 & Pakistani \\
1 & Afghani \\
\hline $\mathbf{N}=\mathbf{2 0}(\mathbf{M}=\mathbf{1 0}, \mathbf{F}=\mathbf{1 0})$ & Local Community \\
20 & Local Residents \\
\hline 40 & Total \\
\hline
\end{tabular}

Local residents were approached on one of the main squares in Newcastle's city centre. For the purpose of this study, we define residents as "local" if they currently reside in Newcastle and never claimed asylum or obtained refugee status in the UK. We aimed for a research sample that is roughly representative of the city's adult population in terms of gender, age and neighbourhood. There was an equal distribution between men and women and an even distribution across an age range from 18 to 68 , with interviewees residing in 10 different neighbourhoods in the city. Participants were asked six questions, the first of which explored local residents' relations with refugees. Based on Hynie's 
concept of community welcome, the second and third question discussed residents' perceptions of refugees and how they view the latter's impact on the city. Again, relying on Hynie, the remaining three questions inquired whether residents perceive Newcastle to be a welcoming city for refugees and which obstacles they believe refugees face in the city.

Of the 17 refugees we spoke to, nine were recruited at NCC's drop-in session for Syrian families. The remaining eight interviewees were recruited at a charity in Newcastle called The Hub Drop-in for Asylum Seekers and Refugees (Hub), where both authors are currently working as Legal Advisers. As this study focuses on the integration experience of recently arrived adult refugees, interviewees had to be over 18 years old and must have obtained their refugee status within the last five years. We further aimed to include a broad range of nationalities and age groups, as well as single and family households, to roughly mirror the diverse refugee population in the city. Participants were asked 20 questions that were split into five sections. The first section enquired about interviewees' own understanding of integration and their feeling of integration in Newcastle. The second section discussed interviewees' employment experiences in the city with the third section exploring participants' relations with local residents. In the fourth section, interviewees were asked about their neighbourhoods, including their feelings of safety and experiences of racism.

We also interviewed three staff members at NCC who play a central role in the council's work with refugees. We spoke to the Coordinator for Migration, Refugee and Asylum, the Coordinator for the City of Sanctuary and a Supported Employment Officer. All of the interviews were loosely structured with several follow up questions inviting the interviewees to elaborate on their answers. The interview with the Supported Employment Officer focused on the support that NCC provides to resettled refugees in the areas of housing and employment. The other two interviews explored the reasons behind NCC's commitment to hosting refugees, changes in council policy over time, as well as the challenges that NCC faces with regards to hosting refugees.

The authors' "insider-position" as Legal Advisers at the Hub-where we advise refugees on a variety of legal matters, usually relating to welfare benefits-has been both an advantage and a disadvantage when undertaking this research. On the one hand, working for an organisation that is in frequent contact with NCC has helped us to gain access to council employees who were willing to be interviewed by us. Moreover, our position was crucial to gain the trust of the refugees we interviewed. On the other hand, the Hub interviews might have been impacted by underlying dynamics of a service provider-client relationship. To mitigate this risk, we predominantly interviewed persons that we had not personally advised at the Hub.

Two crucial limitations need to be mentioned here. Firstly, only 3 of the 17 interviewees with refugee status were women. Thus, female refugees' integration experiences in Newcastle are only marginally represented in this study. Secondly, by recruiting all but one interviewee at two advice services, this research might not reflect the experiences of the most marginalised refugees who do not have access to these services. Moreover, it might also not represent the experience of the most integrated refugees, who do not need any assistance.

\section{Background on Refugees in the United Kingdom}

The adjectives used to describe the UK's history of hosting refugees range from "proud" to "shameful", with much debate over whether the country did-and does-enough to help people fleeing war and disaster (Rampen 2018). From hosting Jewish and Polish refugees during the 1930-40s, Ugandan Asian refugees who were expelled by Idi Amin in the 1970s, Kurdish refugees escaping oppression in the 1980s, to Bosnian and Kosovan refugees in the 1990s, the UK has on many occasions become a new home for people who were forced to leave their countries (Girvan 2018). Today, the largest refugee resettlement programme in the UK is the VPRS with the aim of resettling 20,000 Syrian refugees by 2020. In addition to resettled refugees, who are granted refugee status upon arrival in the UK, many people make their own way to the UK and claim asylum at the border. Both groups will be discussed in the next sections. 


\subsection{Asylum Seekers and the Asylum Dispersal Scheme}

According to the Oxford Migration Observatory, asylum claims in the UK represented less than $5 \%$ of the total number of applications made in European countries in 2017 (Blinder 2019). While the figures for those seeking asylum fluctuated over the last decade, there was an evident peak in 2015 during the "refugee crisis". A total of 1,394,000 applications were made Europe-wide, but only $2.9 \%$ of these were submitted in the UK (ibid.). Moreover, first-time asylum applications are often refused with $68 \%$ in 2017 , of which $35 \%$ were overturned on appeal (ibid.).

While waiting for a decision on their application, asylum seekers are dispersed across the country and hosted by various local authorities. The asylum dispersal scheme was introduced by the Immigration and Asylum Act 1999. Prior to that, the responsibility for support lay with the local authority for the area in which the asylum claim was made. London and the South East have historically attracted the largest numbers, which meant that the pressure fell most heavily on these authorities (HC-1758 2018). The dispersal scheme aimed to provide a more balanced and fair distribution system based on available and more affordable accommodation (Politowski and McGuinness 2016). However, participation in the scheme is voluntary and while the number of asylum seekers has steadily increased since 2012, 'the number of local authorities which have agreed to participate in dispersal has not' (HC-1758 2018, p. 24, para. 69).

Moreover, once a local authority agrees to host asylum seekers, they have very little control over how many people they will host, with the limit being 'an assumption that there will be no more than one asylum seeker per 200 residents, based on the 2001 census figures for population' (Politowski and McGuinness 2016). Even more problematically, in 2012, the government outsourced responsibility for providing asylum seekers with accommodation to private contractors (HC-880 2014). This left local authorities with next to no influence on how and where asylum seekers will be housed in their areas.

\subsection{The Vulnerable Persons Resettlement Scheme (VPRS)}

The VPRS was launched in 2014 with a focus on the most vulnerable and those most at risk. The Home Office works closely with the United Nations High Commissioner for Refugees to identify people for resettlement. In 2015, the government announced an expansion of the scheme to resettle 20,000 Syrian refugees by 2020 (Home-Office 2017). As of February 2018, 10,500 individuals have so far been resettled under the scheme (Home-Office 2018).

Like with the asylum dispersal system, it is voluntary for local authorities to take part in the VPRS. However, the crucial difference is that funding for the scheme is directly paid to local authorities who have full responsibility for housing and supporting resettled refugees. The funding is provided through a combination of government departments. During the first year of the resettlement scheme, local authorities received $£ 8520$ per refugee (HC-768 2017). The discernible difference between resettled refugees under the VPRS and newly recognised refugees who have gone through the asylum system, is the gulf in support. VPRS funding allows local authorities to provide resettled refugees with housing, employment advice and assistance, as well as welfare rights advice and language classes. Yet, no such council support is available for former asylum seekers who depend on the charitable sector and government-run job centres for employment and benefits advice. (Debbonnaire et al. 2017). According to the All-Party Parliamentary Group on Refugees, this gap in support essentially created a two-tier system for refugees in the UK (ibid.).

\subsection{The Route to Citizenship}

Both resettled refugees and former asylum seekers receive five years limited leave to remain (Home-Office 2016a). They are issued with a biometric residence permit which they will require as evidence of their right to work and access to benefits (Home-Office 2016b). They are eligible to apply for indefinite leave to remain ('settlement') within the last 28 days of their five-year leave (Home-Office 2016a). A hardening of the rules has made the prospect of obtaining settlement more difficult. The safe 
return review, introduced in March 2017, guides Home Office caseworkers to consider the situation in an applicant's home country at the date of application and determine whether that person is still in need of protection (Home-Office 2016c). Many observers have highlighted the policy's negative impact on the integration experience of refugees. By reminding refugees that their temporary leave could be taken away, the policy created an atmosphere of uncertainty. Moreover, there is a risk that employers and landlords become less willing to employ and rent to refugees, as they can no longer be certain that a person will obtain settlement. There are also concerns that women who fled female circumcision and domestic violence will be disproportionally affected, as it can be difficult to prove that these threats persist after five years (Desira 2017). If an applicant is successful in obtaining settlement, they can apply for British citizenship after one year (Home-Office 2019).

\section{Background on Refugees in Newcastle}

\subsection{The Socio-Economic Context}

With an estimated population of 296,000, Newcastle is the largest city in the North East of England (ONS 2018a). Sitting on the Northern bank of the River Tyne, Newcastle was once home to a world-leading shipbuilding industry. Coal mining as well as glass and steel manufacturing were other significant parts of the economy. Yet, from the middle of the 20th century onwards, Newcastle entered a phase of deindustrialisation, leading to the decline of its economic prowess. By the end of the century, all coal mining had ceased, the ship industry had shrunk to a bare minimum and manufacturing jobs had decreased in significant numbers. Nowadays, the city's economy centres around service provision, higher education and commerce (Renton 2006).

In recent years, Newcastle has been hard-hit by government austerity policies, introduced after the financial crisis in 2008. The reductions in public spending for NCC between 2011 and 2018 amounted to $£ 254$ million, resulting in crucial council services being cut (Casla et al. 2018). Within the same period, public sector employment in the North East declined by $25 \%$, adding to the job scarcity in the region (Raikes et al. 2018). Unemployment levels in Newcastle are well above the national average, as is the number of households relying on welfare benefits (ONS 2018b). The use of food banks drastically increased in recent years and more people had to rely on NCC for emergency financial assistance, thus putting further pressure on an already strained council budget (ibid.).

The lives and integration of refugees in Newcastle can only be understood within this challenging socio-economic context, which we shall return to throughout this paper.

\subsection{The Response of Newcastle City Council}

Despite drastic cuts in government funding and high levels of deprivation in the city, NCC remained committed to hosting refugees. The city was one of the first local authorities to take part in the asylum dispersal system starting in 1999. According to the Migration, Refugee and Asylum Coordinator, Rowenna Foggie, political support from both the leader of the Council Nick Forbes and his Deputy Cllr Joyce McCarthy has been key for the council's refugee-friendly approach. This support became even more crucial after government austerity reduced the council budget and funding for the asylum dispersal scheme was given to private contractors instead. Since then, "everything became more scrutinised" said Rowenna and allocating funding for refugees turned into political decisions.

In 2014, NCC reaffirmed its commitment to support refugees by declaring itself a city of sanctuary. The political support of the council leadership was again vital for this to happen. The City of Sanctuary (CoS) project in Newcastle was initially led by a group of volunteers, one of whom acted as the coordinator of the project. Yet, after officially endorsing CoS, NCC offered to coordinate the project and relied on its own budget to fund a paid coordinator position. Due to the presence of numerous refugee-supporting charities in the city, $\mathrm{CoS}$ does not focus on service delivery but on raising public awareness and on getting public and cultural institutions to become institutions of sanctuary. This exceeds mere symbolism and requires institutions to make a real contribution. For example, the local 
Tyneside Cinema offers $£ 1.00$ tickets for asylum seekers to see any film. According to Rosie Tapsfield, the current $\mathrm{CoS}$ coordinator, the ultimate goal is "making welcoming refugees everyone's business."

Being an official city of sanctuary had a significant impact on NCC's decision to take part in the VPRS in 2015-one of the first local authorities in the UK to do so. Rowenna Foggie told us, "The Council takes being a City of Sanctuary very seriously. It is an aspiration that motivates." Having declared itself a CoS, Rowenna continued that "taking part in the Syrian Vulnerable Persons Resettlement Scheme just seemed like the right thing to do." Moreover, signing up to the scheme meant that at least some government funding for refugee integration will return to Newcastle, which, Rowenna says "benefits everyone in the city."

Another reason for NCC's active involvement in welcoming refugees and asylum seekers has been the wish to maintain expertise in this area to provide an oversight of the private contractors who, since 2012, are tasked by the government with housing asylum seekers in the city. Over the last seven years, this contract was held by security company G4S and has now been awarded to the Mears Group.

\subsection{Mapping the Refugee Population}

At the height of Newcastle's industrial boom at the turn of the 20th century, many Scottish and Irish migrants came to the city to work in its factories and mines (Renton 2006). However, since that time, the city and surrounding county of Tyne and Wear have been among the least popular destinations for migrants in the UK. Between the years 2004 and 2017, Tyne and Wear has consistently been the region with the third lowest number of foreign-born residents in the UK, totalling 92,000 in 2017. The rest of the North East hosts the lowest number, with a total of 68,000 foreign-born residents in the same year (Vargas-Silva and Rienzo 2018).

While the Home Office records the number of asylum seekers that are dispersed to Newcastle, no data is collected on the number of persons that remain in the city after acquiring refugee status. Yet, since NCC was among the first local authorities to sign up to the asylum dispersal scheme, the number of refugees in the city has certainly increased since the early 2000s. According to NCC, between January 2016 and September 2018, 482 Newcastle-based asylum seekers were granted refugee status and referred to the council's Move-On Team, which helps newly recognised refugees to access housing after they had to leave their asylum accommodation. Of these 482 people, $40 \%$ were rehoused in Newcastle, $2 \%$ moved to friends and family in the city and $20 \%$ left the area. The remaining $38 \%$ either declined the support of the Move-On Team or did not maintain contact. It is not known whether these persons remained in Newcastle or left the city. ${ }^{1}$

In addition to the asylum dispersal system, 71 Syrian families, comprising 295 individuals, have been resettled in Newcastle under the VPRS since 2015. Therefore, it is safe to assume that at least 500 people with refugee status have settled in the city in the last three years. This figure may well be higher, as no data exists on secondary migration to the city. It might also be lower, since people that have initially been rehoused by the council could have left the area by now. ${ }^{2}$

The refugee population in Newcastle is very diverse and includes a large Sudanese, Iranian and most recently a Syrian community. At the Hub, the authors have also supported refugees from Libya, Turkey, Afghanistan, Eritrea, Somalia and Pakistan. Many refugees live in the Western part of Newcastle, in areas such as Fenham, Benwell, Arthur's Hill and Elswick, where housing and living costs are generally lower than in the city's central and northern neighbourhoods. However, Syrians who came to Newcastle through the VPRS tend to be more evenly distributed across the city. According to the Coordinator for Migration, Refugee and Asylum, the council carefully selects suitable areas with a view to ensuring housing needs and community cohesion.

This data was shared with the authors by Newcastle City Council but is not publicly available. Ibid. 


\section{The Integration Experience}

\subsection{Employment}

Just over half of the 17 people we spoke to had come to the UK in the years 2015-2016. Four persons had arrived during the period 2017-2018 and the remaining four came in 2006 and 2010. Of the 17 interviewees, eight are currently in paid employment and all expressed the desire to be working in the future. Those currently unemployed are dependent on Universal Credit and other welfare benefits to survive. Three are unable to work because of health problems, with a fourth caring full time for his sick wife and their two children. The others mentioned the lack of language skills as a major barrier to finding employment. Likewise, those currently employed identified language skills as key for finding work. Although 13 of the 17 interviewees are currently enrolled in English language (ESOL) courses, many described interacting with colleagues and customers at work as the experience that has been most helpful in learning English. As one interviewee from Syria put it, "The government should put refugees in jobs, because work helps much more to learn English than ESOL." This reciprocal relationship between language skills and employment is a good example of what Strang and Ager (2010) called 'resource acquisition spirals', whereby possession of one resource, such as work, can easily lead to the acquisition of another, such as language skills (Strang and Ager 2010).

Interestingly, the data suggests a correlation between the age of participants and their success in finding work. The three oldest interviewees are all unemployed, despite having worked for many years as a restaurant owner, a university lecturer and an electrician in their respective home countries. Two of the three youngest interviewees, on the other hand, are currently in paid employment with the third having recently been forced to stop working due to an injury. Language skills seem again to play a crucial role in this regard, with the younger interviewees speaking better English than the older participants. Moreover, all the older interviewees stated that it is 'very difficult' to learn the language. The oldest interviewee, who gained refugee status through the dispersal system, further criticised NCC for not providing enough support in finding employment and the absence of information in his mother tongue.

The data suggests that access to employment advice is indeed crucial for refugees to find work. Three of the eight interviewees who are currently working told us that they found a job with the help of the Supported Employment Officer at NCC. The latter helped the interviewees to develop their skills, gain practical experience and enhance their confidence. For example, NCC recently organised a public food-tasting session in one of the city's libraries, at which refugees prepared food from their home countries. The event aimed to improve refugees' employability skills with the ultimate goal of enabling participants to start their own food-truck or restaurant (Tapsfield 2019). However, the Supported Employment Officer is only funded to assist refugees resettled under the VPRS. Former asylum seekers have to depend on government-run job centres or on local charities for employment advice. In this regard, previous research identified job centres' lack of experience in working with refugees, as well as incidents of wrong advice, as major obstacles to efficient service delivery (Debbonnaire et al. 2017). This may in part account for the high number of refugees who rely on charitable organisations like the Hub for benefits and employment advice. One of the interviewees who gained refugee status through the asylum system has recently found a job with the help of the Hub. However, as the charitable sector operates with limited funding, organisations in the city are often faced with a need for employment and welfare advice that cannot be met by the resources at its disposal. This is one of the many examples of how a lack of support for former asylum seekers, caused by a lack of government funding, is aggravating the integration process of this group of refugees.

Those who are employed tend to work in low-paid jobs in construction work, caring and service provision. This mirrors the findings of a larger study on the employment of migrants in the North East of England, which found that refugees were disproportionately working in low-skilled and low-paid jobs (Vickers et al. 2016). Furthermore, while employment often leads to enhanced language skills, working in low-paid jobs, which often requires employees to work for long hours to make ends meet, 
may keep refugees from gaining formal language qualifications (Braddell and Miller 2017). This applies particularly to persons who have limited exposure to English at their job. One interviewee told us that he recently dropped out of his ESOL course as he was too busy with work. This may lead to what Braddell and Miller (2017) call the low-pay, limited-English trap, where a person, lacking the time to attend formal language courses, 'is left reliant on self-directed learning' (ibid., p. 313).

One of the main causes of the high proportion of refugees in low-skilled jobs seems to be that refugees' previous qualifications are not recognised in the UK. Four of the people we interviewed expressed frustration that their educational and professional qualifications were of little value to them when looking for work. One interviewee, who was a qualified nurse in Uganda but is now retraining and enrolled on a nursing course, told us, "I already did all that in Uganda. I feel like I'm going back instead of going forward. Opportunities are being robbed of me." One of the interviewees who voiced similar frustration is the only one working in a high-skilled role at the government's tax department. Having arrived in the UK in 2006, the university degree from his home country proved of little use, forcing him to retrain and work as a taxi driver on the side. Examples like these point to an unnecessary lose-lose situation, in which newcomers are prevented from achieving their full potential and society misses out on the contribution that refugees could make.

Employment is viewed as essential by all interviewees, not only for providing financial security, but also as a way to learn English and establish social connections. When asked about their own understanding of integration, "having work" featured prominently among the answers. One interviewee said that she only considers herself fully integrated once she feels "fulfilled in my career". Interviewees also valued the daily routine that work provides and highlighted its importance for their emotional stability. As one person told us, "Work is helping me to get myself together. It keeps me active and keeps me from sitting at home and worrying." Employment was further described as enhancing interviewees' self-esteem. One person said, "[my work] shows my potential and gives me confidence". Interestingly, refugees being employed was also viewed positively by local residents, despite the job scarcity of the region. When asked in what way refugees contribute to Newcastle, seven of the 20 local residents we spoke to said that refugees contribute by working, which supports the local economy.

\subsection{Housing}

Based on Ager and Strang's conceptual framework, housing is another key domain that influences an individuals' experience of integration. We identified three common themes: feelings about the city and residing neighbourhood, feelings of safety and experiences of racism, prejudice and discrimination.

All 17 persons we spoke to live in council owned social housing. The prevailing mood in terms of quality of housing and geographical location within the city was very positive, with 15 interviewees expressing a favourable opinion of their area and neighbourhood. The following reasons were mentioned: good relations with neighbours; people from one's own national community living close by; and proximity to Middle Eastern/halal food stores, the local mosque, health services such as the hospital and recreational areas. The small size of Newcastle and cheap housing and transport costs were also cited. Moreover, participants often mentioned the familiarity with their neighbourhood and knowledge of the local geography. As one interviewee said, "We like the area because we got used to it." Yet, two interviewees conceded that they would prefer to live in a house rather than a flat as this would enable them to have a garden.

Regarding feelings of safety, the data revealed significant differences in experience between those resettled through the VPRS and those who gained refugee status through the asylum system. From the 17 interviewees we surveyed, 13 felt safe in their respective neighbourhoods and within Newcastle. Looking at the two groups individually showed that all Syrian participants reported feeling safe. Yet, only four of the eight interviewees who did not arrive through the VPRS said they feel safe. Two of the participants from this group said they felt 'more or less' safe with one disclosing they had been a victim of a violent attack resulting in grievous bodily harm and the other experiencing previous racist and misogynistic abuse with additional threats of violence. 
When we compare the perception of safety with experiences of racism and discrimination, we start to understand the contrast in results between the two groups. The Syrian participants reported no problems with racism and discrimination, except from occasional staring and sideway glances on public transport. As one person told us, "My wife wears a hijab and sometimes I notice people looking at us in a strange way. This happened on the bus. But it doesn't happen too much." However, these findings need to be treated with care. Unlike many former asylum seekers, most Syrians only arrived in Newcastle recently and their level of English is very limited. Therefore, they may simply not understand whether someone is verbally racist towards them. As one Syrian remarked, "I never had any problems, but I also would not understand if someone said anything." Furthermore, eight of the nine Syrians we interviewed were men with the only female interviewee not wearing a veil. Statistics of the local police force show that the overwhelming majority of faith-based hate crimes in the city is directed towards Muslims, with a total of 133 reported incidents in 2017/18 (Northumbria Police 2019a). Thus, it is safe to assume that Syrian Muslim women who are veiled are much more likely to have experienced racism. Despite these limitations, the key finding is that Syrian interviewees seem to face low levels of discrimination, which likely correlates to their strong feeling of safety.

This stands in stark contrast to the other group, as six of eight participants described experiences of some form of racism or discrimination, which likely accounts for their reduced feeling of safety. Half of them detailed verbal racist abuse on several occasions, with many incidents taking place in the city centre. This again supports hate crime data from the local police, with the city centre showing the highest proportion of reported incidents (Northumbria Police 2019b). The reasons for the high level of experienced racism and discrimination among the former asylum seekers will be numerous. However, one potential factor could be that five of the interviewees in this group are black and might thus be more readily presumed to be foreigners. This was also echoed in the observation of one Syrian interviewee who said, "I never made bad experiences because I look more European. But some of my friends who have dark skin have faced some racist situations."

The data further points to a correlation between experiences of racism and interviewees' place of residence. Half of the participants who passed through the asylum system currently live in the West End neighbourhoods of Elswick, Benwell, Arthur's Hill and Fenham. Another interviewee is planning on moving to the area in the near future. A recent report found that the West End neighbourhoods are the most ethnically diverse in Newcastle and have the largest proportion of non-English speaking languages with a third of people living in these areas being born outside the UK (Know Newcastle 2018). When asked what they like about the area, participants commonly mentioned the presence of other people from their national communities. While none of the five interviewees who live, or plan to live, in the West End explicitly stated that they chose the area to avoid racism, it is noteworthy that four reported to have experienced racism in other parts of the city. Moreover, interviewees often spoke positively about the West End by comparing it to other areas. As one interviewee told us, "It is ok here. Better than Byker-that's a racist area." This suggests that avoiding racism is certainly a contributing factor to interviewees' choice of neighbourhood. Similar conclusions were drawn by Phillimore (2008) who found that for refugees in Birmingham, the avoidance of racism was a 'key variable when deciding where to live' (Phillimore 2008, p. 587).

Paradoxically, there is a risk that moving to the West End in order to avoid racism and discrimination might have the opposite effect. Although 73\% of participants in the 2017 Newcastle Residents' Survey said they agree that people from different backgrounds in their neighbourhood get on well together, the concentration of refugees in the West End might negatively impact on local residents' perceptions of refugees (BMG Research 2017). Referring to the West End areas, one local resident told us, "It's almost like ghettos." Moreover, as Elswick and Westgate were ranked the third and fifth most deprived wards in Newcastle, refugees in these areas are likely to compete with other residents for strained resources and services (ibid.).

However, it must be stressed that refugees' move to the West End is often driven by economic necessity and lack of options, rather than individual preference. With social housing being scarce 
in Newcastle, the housing costs in the Western parts of the city are generally lower than in other parts. Moreover, private contractors have increasingly housed asylum seekers in the area. After the government decided to outsource the provision of asylum accommodation to the private sector, NCC has had very little influence on this development. Furthermore, the previous contract holders G4S and Jomast operated a shared-room policy for asylum seekers which significantly increased the resident density in the area. Aware of this problem, NCC attempts to evenly distribute VPRS refugees across the city, with a view to ensuring the sustainability of the housing market (NCC 2018). The nine Syrians we interviewed live in different areas across the city and none resides in West End neighbourhoods. This again highlights the discrepancy in support between the two groups of refugees.

\subsection{Social Relations}

\subsubsection{Residents' and Refugees' Perception of Each Other and Their City}

While four local residents think that racism is a real problem in Newcastle, the majority views the city as a welcoming and friendly place. Many residents made comparisons between Newcastle and other cities to justify their answers. Interestingly, four local residents felt that the city is welcoming but not the people. It was not clear whether their use of "city" was referring to government institutions or the city as such. Residents' views are mirrored in Newcastle's national reputation for being a friendly city. In a recent report by Provident, Newcastle ranked second as the friendliest and sixth as the most welcoming place in the UK (PFG 2018). This seems to correspond with the positive view that the refugees we spoke to have of Newcastle and the local population.

However, a more complex picture emerges when we examine the way in which both refugees and local residents frame the occurrence of racism in Newcastle. The refugees we spoke to were reluctant to discuss racist experiences and tended to describe them as one-off incidents carried out by troubled individuals. One interviewee exclaimed "Mostly people are friendly. But I did make bad experiences six times. Three times people shouted racist abuse at me in the city centre." One of the female interviewees used similar wording when she said, "I think people are very friendly around Newcastle. But I once went out on a date with a local English guy. I told him I just want to be friends, but he wanted to get intimate. When I refused him, he started to shout racist things at me." Similarly, a Syrian interviewee concluded his account of a racist incident that his friend had experienced with the sentence, "But it does not happen a lot". While these accounts start with the caveat that "mostly people are friendly", they then proceed to reveal traumatic and multiple experiences of racism that stand in stark contrast to the initial claim that people are friendly. Kirkwood and others note that 'refugees may find themselves in a particularly difficult situation, as they are reliant on the host society for protection, so any accusations of racism may be taken as ungrateful as well as raising questions about the legitimacy of their claims of persecution in the countries they have fled' (Kirkwood et al. 2012, pp. 26-27). Thus, while the statement that "mostly people are friendly" may well be interviewees' opinion, it could also function as a way for participants to talk about their experiences of racism without appearing to be 'ungrateful' in the eyes of the host society.

The interviews with local residents point to a similar framing of racism in the city. The majority of interviewees perceived other residents to be welcoming toward refugees and assigned racism to " $a$ small minority on the margins" of Newcastle's society. One person referred to "uneducated poverty-stricken residents" as the main perpetrators of racism. The phrase "mostly people are friendly" was also frequently used in their answers. Yet, local residents will employ this particular framing of racism for different reasons. Augoustinos and Every (2010) have argued that the downplaying of racism amongst majority groups attends to their positive self-presentation. This was evidenced in the interviews, where the framing of racism as a minor problem was often accompanied by descriptions of a positive self-image, 
such as, "we Geordies are friendly"3 or "we don't give in to fear-mongering — this is a leftist city". However, the portrayal of Newcastle as a welcoming place for refugees could also be seen as a conscious 'city branding' effort that aims to marginalise more hostile voices (Dekker et al. 2015). Thus, local residents' assignment of racism to a small fraction of society may not necessarily be rooted in a denial of racism in the city. Yet, locating racism exclusively at the margins of society risks minimising more entrenched problems of racial discrimination in Newcastle, as have been highlighted in the testimonials of the refugees we interviewed.

\subsubsection{Relations between Refugees and Local Residents}

Of the 20 local residents we spoke to, 14 voiced an overall welcoming attitude towards refugees. However, only four local residents have previous experience of interacting with refugees. Nonetheless, all but one interviewee had nothing negative to say about them. One interviewee held precisely that view when he said, "I am yet to see a direct negative impact." Many residents valued refugees' economic contribution and the diversity they bring to the city. Refugees were often referred to as friendly, grateful and more law-abiding than UK natives. Although the above outlined dynamics that may lead to a downplay in racism must be borne in mind, most refugees described the majority of the local population as friendly and helpful.

Although both groups view each other in a positive light, the interviews showed that there are very little personal relations between refugees and local residents. None of the local residents mentioned having friends who are refugees. Two residents said they know a refugee through a mutual friend but could not remember when they last saw or spent time with them. Another resident attends a drop-in for refugees but again only interacts with them within the confines of the project. Two further residents engage with refugees in a professional capacity, teaching English and music respectively, rather than on a personal level. Of the 17 refugees we spoke to, only six said they have English acquaintances and friends. The latter reported to have established these friendships with colleagues at work, with classmates in school, or by attending projects and events at charitable organisations like the Hub. Many also told us about being on good terms with their neighbours and having occasional small talk. One Syrian refugee had befriended his neighbour. Yet, others reported being avoided or ignored by local residents. One interviewee told us, "My neighbour does not speak to me. I don't know why".

Moreover, only three local residents voiced an interest in meeting or establishing friendships with refugees. The language used by many local residents further implied that the burden to adapt and change lies with the refugees. When asked what obstacles refugees are likely to face in Newcastle, one person said, "Lack of integration in terms of customs. We may do things in a certain way that they may not understand." Another told us, "The city is very English - I can imagine it's not easy to integrate here." However, none of the interviewees mentioned a need for the host community to change and adapt, too. Thus, while positive attitudes toward refugees are prevalent amongst local residents, their view of integration as a one-way process, as well as the lack of interaction, show that the community welcome is limited.

In contrast, many refugees told us that they are eager to meet local people and establish friendships. As one refugee from Iran put it, "Having contact to locals is important. It makes things easier, and it's nice to connect with your neighbour." Two interviewees, who are also the youngest among the refugees we interviewed, explicitly stated that having English friends was an important part of feeling integrated. Of the six refugees who reported acquaintances with local residents, five were aged between 20 and 36 and constituted the youngest interviewees. This suggests that forging relations with locals is more important for younger people, who also appear to be more successful at it. One reason for this is certainly that the younger interviewees tended to speak better English. This corresponds to many older refugees identifying their limited language skills as a major barrier to establishing relations with locals.

3 Colloquial term that is used to describe people from Newcastle. 
Cultural differences were cited as a further barrier to building relations with locals. This was again predominantly mentioned by older interviewees. As one older Syrian participant told us, "Everything is different here. Everyone is busy. It's a different culture." Another said that it had taken him a long time to discover that he must take the first step, "If you don't talk to [people], then they will not talk to you." While none of the younger interviewees described cultural differences as an obstacle to forging relations with locals, they too reported facing difficulties. For example, one younger interviewee described facing frequent prejudice from colleagues at work and fellow students at her nursing course. She told us, "Making friends with local people can be hard, because they often look down on me and behave in a really patronising way. They have a lot of stereotypes. Even though I speak better English than some of the locals in my class."

\subsubsection{Relations with National Community}

Besides forming social relations with local residents, interacting with other people from their respective home countries is of great importance to the refugees we talked to. Interviewees valued conversing in their mother tongue and sharing experiences about their life in Newcastle with other members of their national group. This applies to both the resettled refugees and those that came to the UK as asylum seekers. All but one of the 17 interviewees stated that they are in some capacity engaged with their national communities. The interactions range from socializing and sharing experiences to celebrating national festivities, as well as accessing support and advice on employment, education and immigration matters. Seven of the nine Syrian interviewees said that they frequently visit or are being visited by other Syrians. Two of the people we spoke to stated that they like their neighbourhoods, because other members from their community live close by. A third told us that he plans to move from his current home to the area where the Iranian Refugee Community Organisation (RCO) is based. Referring to his community, one person said, "Nobody understands you as well as they do". This was echoed by an interviewee from Afghanistan who said, "English people do not know about the challenges that refugees face. But the Afghani community can help." Previous research has highlighted that based on their insight of what it means to be a refugee, RCOs are often able to design solutions for refugees that other organisations cannot offer (Williams 2018). The example of one Syrian interviewee, who has recently found employment as a construction worker through another Syrian, shows the positive outcomes of community relations on integration objectives like employment.

\subsection{Attitudes toward the Future}

Despite the upheaval inherent in uprooting their lives and the challenges they face in Newcastle, the refugees we spoke to are optimistic about their future. They all expressed dreams and ambitions they aspire to. All participants expressed the desire to be in stable and fulfilling work and five would like to set up their own businesses. A total of 13 interviewees can see themselves remaining in Newcastle, citing their children's education, work, friendships formed and a familiarity with the city as their reasons. One interviewee contemplates moving to Manchester or London for more job opportunities, with two others acknowledging they may move at some point for the same reason. Two of the Syrian interviewees would consider returning to Syria if the situation was stable. When asked where he sees himself in five years, one interviewee was clear when he said, "I will be back home".

The majority of those we interviewed see naturalisation as a British citizen as something to aim for. When pressed upon why this was important to them, being able to travel and having better opportunities in the UK were the main reasons given. Of those that wish to travel, many specifically mentioned that they would like to visit their home countries.

Three interviewees strive to pursue higher education. As previously mentioned in the housing section, two interviewees hope to one day have a house with a garden. Tellingly, one declared, "I want my kids' life to be better than mine. I'm 35, my life is not important, but the lives of my children are." Whether it is the pursuit of employment, education, entrepreneurship or the wish to provide a better future for their children, the outlook is a positive one for all the people we spoke to. 


\section{Conclusions}

After decade-long austerity policies, Newcastle faces high levels of deprivation, a lack of social housing and above average unemployment rates. Despite these challenges, the city has remained committed to hosting refugees by taking part in the asylum dispersal scheme as well as the VPRS. Our research has shown that, besides political support from the council leadership, becoming a city of sanctuary has had a significant impact on Newcastle's adoption of refugee-friendly policies.

Overall, the refugees we spoke to hold favourable opinions of Newcastle and the local population and many are planning to stay in the city in the future. This was mirrored by local residents who voiced positive views of refugees, with the majority of interviewees recognising the contribution that refugees can make including supporting the local economy by working. However, the level of personal interaction between residents and refugees is very low, with language barriers and prejudice being named as major obstacles. Older refugees find it particularly difficult to forge relations with locals and cited cultural differences as one of the reasons. The fact that many local residents view integration as a one-way process, with the burden to adapt falling on the refugees, is likely to further obstruct the forging of relations between the two groups.

Moreover, experiences of racism and discrimination among large parts of the interviewed refugees is a major concern and negatively impacts on their feelings of safety. This paper observed that the exposure to racism is particularly high among former asylum seekers, especially those with darker skin colour. This was shown to result in a lower sense of safety among former asylum seekers, compared to resettled refugees. The analysis further suggested that both refugees and locals may downplay the occurrence of racism in the city, albeit for different reasons. There is thus a risk that problems of racism in the city will not be adequately addressed.

Those refugees who are working tend to be concentrated in low-skilled and low-paid jobs. A lack of language skills, age and previous qualifications not being recognised were shown to be major barriers for refugees attempting to find work and progress in their careers. Nonetheless, interviewees highly valued work as a way to improve their English, meet locals, follow a daily routine, enhance their self-esteem and support their families.

The areas of employment and housing further highlight the gulf in support between former asylum seekers and those refugees who came to Newcastle through the VPRS. While the latter group is evenly distributed across the city, the former tends to congregate in the Western and most deprived part of the city. Moreover, former asylum seekers often have to rely on an underfunded and overburdened charitable sector for housing and employment advice. Resettled refugees on the other hand are supported by designated staff at NCC. This discrepancy is a manifestation of what has essentially become a two-tier system of refugee integration in the UK. While local authorities receive funding for the integration of people under the VPRS, the integration of former asylum seekers continues to be aggravated by austerity policies. There is no good reason for this. The positive experience of Syrian refugees in Newcastle shows that the VPRS is working. It is time that the model of the scheme is adopted for all refugees in the UK.

Author Contributions: The research idea and research design were conceptualised by M.F. Both authors collected and analysed the research data and collectively drafted and finalised the manuscript.

Funding: This research received no external funding.

Conflicts of Interest: The authors declare no conflict of interest.

\section{References}

Ager, Alastair, and Alison Strang. 2008. Understanding Integration: A Conceptual Framework. Journal of Refugee Studies 21: 166-91. [CrossRef]

Augoustinos, Martha, and Danielle Every. 2010. Accusations and denials of racism: Managing moral accountability in public discourse. Discourse and Society 21: 251-56. [CrossRef]

Berry, John. 1997. Immigration, Acculturation, and Adaption. Applied Psychology: An International Review 46: 5-34. 
Blinder, Scott. 2019. Migration to the UK: Asylum and Refugees. The Migration Observatory at the University of Oxford, January 4. Available online: https://migrationobservatory.ox.ac.uk/resources/briefings/migration-tothe-uk-asylum/ (accessed on 3 April 2019).

BMG Research. 2017. Newcastle Residents' Survey 2017. Prepared for Newcastle City Council. Prepared by BMG Research. November. Available online: https://www.newcastle.gov.uk/sites/default/files/wwwfileroot/yourcouncil-and-democracy/statistics-and-census-information/newcastle_residents_survey_2017.pdf (accessed on 11 April 2019).

Bowskill, Matt, Evanthia Lyons, and Adrian Coyle. 2007. The Rhetoric of Acculturation: When Integration Means Assimilation. The British Journal of Social Psychology 46: 793-813. [CrossRef] [PubMed]

Braddell, Alexander, and Linda Miller. 2017. Supporting Migrants in Low-Paid, Low-Skilled Employment in London to Improve Their English. The Linguistic Integration of Adult Migrants. March. Available online: https://www.academia.edu/33156323/Supporting_migrants_in_low_paid_low_skilled_employment_ in_London_to_improve_their_English (accessed on 2 April 2019).

Casla, Koldo, Allyson Pollock, Ted Schrecker, Joel Halligan, Suzanne Moffatt, Vera Araujo-Soares, Clare Bambra, Chris Allan, Tracy Shildrick, Peter Hopkins, and et al. 2018. Written submission: Visit by the UN Special Rapporteur on Extreme Poverty and Human Rights, Philip Alston, to the UK from 5 to 16 November 2018. Available online: https://www.ohchr.org/Documents/Issues/EPoverty/UnitedKingdom/2018/Academics/ Newcastle_University_Institute_of_Health_and_Society.pdf (accessed on 1 July 2019).

Castles, Stephen, Maja Korac, Ellie Vasta, and Steven Vertovec. 2002. Integration: Mapping the Field. Report of a Project Carried Out by the University of Oxford Centre for Migration and Policy Research and Refugee Studies Centre Contracted by the Home Office Immigration Research and Statistics Service (IRSS). Home Office Online Report 28/03. London: Home Office.

Debbonnaire, Thangam, David Alton, David Burrowes, Alf Dubs, Paul Butler, Barbara Janke, Anne McLaughlin, Ruth Lister, and Caroline Lucas. 2017. Refugees Welcome? The Experience of New Refugees in the UK: A Report by the All Party Parliamentary Group on Refugees. April. Available online: https://www.refugeecouncil. org.uk/wp-content/uploads/2019/03/APPG_on_Refugees_-_Refugees_Welcome_report.pdf (accessed on 6 April 2019).

Dekker, Rianne, Henrik Emilsson, Bernhard Krieger, and Peter Scholten. 2015. A Local Dimension of Integration Policies? A Comparative Study of Berlin, Malmö, and Rotterdam. International Migration Review 49: 1-26. [CrossRef]

Desira, Chris. 2017. Safe Return Reviews and Home Office Policy on Settlement for Refugees. Free Movement Blog. June 22. Available online: https://www.freemovement.org.uk/in-depth-look-at-the-new-home-officesettlement-policy-for-refugees-after-five-years/ (accessed on 12 April 2019).

Fekete, Liz. 2008. Integration, Islamophobia and Civil Rights in Europe. The Institute of Race Relations. Available online: http://www.irr.org.uk/publications/issues/integration-islamophobia-and-civil-rights-in-europe/ (accessed on 12 June 2019).

Girvan, Alyssa. 2018. Resources. Interactive Timelines. Available online: http://refugeehistory.org/interactivetimelines (accessed on 3 April 2019).

HC-1758. 2018. Asylum Accommodation: Replacing COMPASS. Home Affairs Select Committee Thirteenth Report of Session 2017-2019. House of Commons. December 11. Available online: https://publications.parliament.uk/ pa/cm201719/cmselect/cmhaff/1758/1758.pdf (accessed on 20 March 2019).

HC-768. 2017. The Syrian Vulnerable Persons Resettlement Programme. Committee of Public Accounts Thirty-fourth Report of Session 2016-2017. House of Commons. January 13. Available online: https://publications. parliament.uk/pa/cm201617/cmselect/cmpubacc/768/768.pdf (accessed on 8 April 2019).

HC-880. 2014. Home Office COMPASS Contracts for the Provision of Accommodation for Asylum Seekers. National Audit Office, January. Available online: https://www.nao.org.uk/wp-content/uploads/2014/01/10287-001accommodation-for-asylum-seekers-Book.pdf (accessed on 29 March 2019).

Home-Office. 2016a. Immigration Rules Part 11: Asylum. Paragraph 339Q(i). February 25. Available online: https: //www.gov.uk/guidance/immigration-rules/immigration-rules-part-11-asylum (accessed on 10 April 2019).

Home-Office. 2016b. Biometric Residence Permits (BRPs): General Information for In-Country Applicants, Their Employers and Sponsors. Guidance Notes. July. Available online: https://assets.publishing.service.gov.uk/government/ uploads/system/uploads/attachment_data/file/539328/In-Country_information_leaflet_-_July_2016.pdf (accessed on 10 April 2019). 
Home-Office. 2016c. Asylum Policy Instruction Settlement Protection. February 2. Available online: https://assets.publishing.service.gov.uk/government/uploads/system/uploads/attachment_data/file/ 497326/settlement_protection_v4.0_EXT.pdf (accessed on 10 April 2019).

Home-Office. 2017. Syrian Vulnerable Persons Resettlement Scheme (VPRS). Guidance Notes. July. Available online: https://assets.publishing.service.gov.uk/government/uploads/system/uploads/attachment_data/file/ 631369/170711_Syrian_Resettlement_Updated_Fact_Sheet_final.pdf (accessed on 11 April 2019).

Home-Office. 2018. Over 10,500 Refugees Resettled in the UK under Flagship Scheme. UK Visas and Immigration. February 22. Available online: https:/www.gov.uk/government/news/over-10000-refugees-resettled-in-theuk-under-flagship-scheme (accessed on 29 March 2019).

Home-Office. 2019. Naturalisation Booklet-The Requirements. Guide AN. March. Available online: https://assets.publishing.service.gov.uk/government/uploads/system/uploads/attachment_data/file/ 794168/Guide_AN_Naturalisation_Booklet.pdf (accessed on 12 April 2019).

Hynie, Michaela, Ashley Korn, and Dan Tao. 2016. Social Context and Integration for Government Assisted Refugees in Ontario, Canada. In After the Flight: The Dynamics of Refugee Settlement and Integration. Edited by Morgan Poteet and Shiva Nourpanah. Newcastle upon Tyne: Cambridge Scholars Publishing.

Kirkwood, Steve, Chris McVittie, and Andrew McKinlay. 2012. 'They're more than animals': Refugees' accounts of racially motivated violence. British Journal of Social Psychology 52: 747-62. [CrossRef] [PubMed]

Know Newcastle. 2018. Newcastle Future Needs Assessment. April 27. Available online: file://C:/Users/jhuss/Downloads/Know_Newcastle_People_living_in_Newcastle_-_B_-_May_17_revised_april_2018.pdf (accessed on 11 April 2019).

Mulvey, Gareth. 2010. When Policy Creates Politics: The Problematizing of Immigration and the Consequences for Refugee Integration. Journal of Refugee Studies 23: 437-62. [CrossRef]

Newcastle City Council. 2018. Written Evidence Submitted by Newcastle City Council. Available online: https://www.parliament.uk/business/committees/committees-a-z/commons-select/home-affairscommittee/inquiries/parliament-2017/asylum-accommodation-inquiry-17-19/ (accessed on 10 June 2019).

Northumbria Police. 2019a. Hate Crimes_068/19. Freedom of Information Act (2000) Request. March 26. Available online: https://beta.northumbria.police.uk/about-us/publications-and-documents/accessing-information/ disclosure-log/crime-statistics/hate-crimes-06819/ (accessed on 8 April 2019).

Northumbria Police. 2019b. Hate Crimes-311/19. Freedom of Information Act (2000) Request. March 26. Available online: https://beta.northumbria.police.uk/about-us/publications-and-documents/accessing-information/ disclosure-log/crime-statistics/hate-crimes-31119/ (accessed on 8 April 2019).

Office for National Statistics (ONS). 2018a. Labour Market Profile-Newcastle upon Tyne. Available online: https://www.nomisweb.co.uk/reports/lmp/la/1946157065/report.aspx (accessed on 4 April 2019).

Office for National Statistics (ONS). 2018b. Overview of the UK Population: November 2018. Available online: https:/www.ons.gov.uk/peoplepopulationandcommunity/populationandmigration/ populationestimates/articles/overviewoftheukpopulation/november2018 (accessed on 25 March 2019).

Pastore, Ferruccio, and Irene Ponzo, eds. 2016. Tackling the Dilemma of Local Variations in Ethnic Conflict and Integration. In Inter-Group Relations and Migrant Integration in European Cities. Cham, Heidelberg, New York, Dordrecht and London: Springer.

Provident Financial (PFG). 2018. Unbroken Britain Map: Find the UK's Friendliest Areas. October. Available online: https://www.providentpersonalcredit.com/unbroken-britain-community-survey/ (accessed on 11 April 2019).

Phillimore, Jennifer. 2008. Refugees, acculturation strategies, stress and integration. Journal of Social Policy 40: 575-93. [CrossRef]

Politowski, Ben, and Terry McGuinness. 2016. Policy on the Dispersal of Asylum Seekers. House of Commons Library, April 29. Available online: https://researchbriefings.parliament.uk/ResearchBriefing/Summary/CDP2016-0095 (accessed on 2 April 2019).

Raikes, Luke, Leah Millward, and Sarah Longlands. 2018. State of the North 2018-Reprioritising the Northern Power House. Institute for Public Policy Research (IPPR). Available online: https://www.ippr.org/files/2018-12/sotn2018-web.pdf (accessed on 5 April 2019).

Rampen, Julia. 2018. Britain's treatment of refugees fleeing the Nazis is a story of brutality cloaked in bureaucracy. NewStatesman. January 27. Available online: https://www.newstatesman.com/politics/uk/2018/01/britain-streatment-refugees-fleeing-nazis-story-brutality-cloaked-bureaucracy (accessed on 1 April 2019). 
Renton, David. 2006. Crossing Occupation Borders: Migration to the North-East of England. University of Johannesburg Autumn. Available online: https://www.history.ac.uk/ihr/Focus/Migration/articles/renton.html (accessed on 1 April 2019).

Strang, Alison, and Alastair Ager. 2010. Refugee Integration: Emerging Trends and Remaining Agendas. Journal of Refugee Studies 23: 589-607. Available online: https://doi.org/10.1093/jrs/feq046 (accessed on 10 April 2019). [CrossRef]

Tapsfield, Rosie, poster. 2019. FoodWorks Treats. 2019. Newcastle City of Sanctuary. Video. April 15. Available online: https://youtu.be/FxdG4jC8XjU (accessed on 9 April 2019).

Vargas-Silva, Carlos, and Cinzia Rienzo. 2018. Migrants in the UK: An Overview; The Migration Observatory at the University of Oxford. October. Available online: https://migrationobservatory.ox.ac.uk/resources/briefings/ migrants-in-the-uk-an-overview/ (accessed on 7 April 2019).

Vickers, Tom, John Clayton, Hilary Davison, Lucinda Hudson, Maria Aurora Cañadas Romero, Paul Biddle, Sara Lilley, Georgina Fletcher, and Michal Chantowski. 2016. New Migrants' in the North East Workforce: Final Report; Nottingham Trent University, November 18. Available online: http://irep.ntu.ac.uk/id/eprint/29159/ (accessed on 6 April 2019).

Whiteman, Ruth. 2005. Welcoming the stranger: A qualitative analysis of teachers' views regarding the integration of refugee pupils into schools in Newcastle upon Tyne. Educational Studies 31: 375-91. [CrossRef]

Williams, Dick. 2018. A Bridge to Life in the UK Refugee-Led Community Organisations and Their Role in Integration. Refugee Council. October. Available online: https:/www.refugeecouncil.org.uk/wp-content/uploads/2019/ 03/A_bridge_to_life_in_the_UK_Oct_2018.pdf (accessed on 5 April 2019).

(C) 2019 by the authors. Licensee MDPI, Basel, Switzerland. This article is an open access article distributed under the terms and conditions of the Creative Commons Attribution (CC BY) license (http://creativecommons.org/licenses/by/4.0/). 
Article

\title{
Formal Education of Asylum Seeker Children in Belgrade, Serbia: Expanded Meaning of Social Inclusion
}

\author{
Teodora Jovanović \\ The Institute of Ethnography of the Serbian Academy of Sciences and Arts, 11000 Belgrade, Serbia; \\ teodora.jovanovic@ei.sanu.ac.rs
}

Received: 23 April 2019; Accepted: 2 July 2019; Published: 6 July 2019

\begin{abstract}
Formal education of asylum seeker children in Serbia officially started in September 2017, when the consequences of European border regime became more obvious. In spite of the official attitude that Serbia is a transit country, there was a pressure to improve integration policies regarding migration, since a lot of people wanting to seek asylum in European Union have remained in Serbia for months. Educational inclusion is the aspect of asylum seekers' integration in which the most resources and effort was invested. In this article, I try to define the notions of social and educational inclusion in relation to integration policies of asylum seekers coming from different cultural backgrounds and in relation to existing educational inclusion policies.
\end{abstract}

Keywords: inclusion; intercultural; education; asylum seeker; difficulty; diversity

\section{Introduction}

When it comes to the notion of social inclusion, "in recent years it has taken on a broader usage in response to the increasing diversity within school communities, including cultural and linguistic diversity" (Taylor and Sidhu 2012, p. 53). Scholarly approaches to educational inclusion vary among the context of physical disability, cognitive disability, multi-cultural and multi-lingual education. In this paper, multi-cultural and multi-lingual education is considered, with the focus on asylum seekers from Afghanistan, Iran, Syria, Iraq, Pakistan, and other countries from the Middle East, who live in reception centers in Serbia. I am examining the process of asylum seeker's enrollment in elementary schools in Belgrade. Three main themes are considered through interviews with research participants and literature review: the beginning of formal education of asylum seeker children in Serbia, intercultural education, and the notion of social inclusion. The central research question is how the social inclusion is understood in regard to cultural diversity. Various perspectives are taken into account: teachers', NGO representatives', government officials', refugees' and scholars'. The objective of this paper is to provide understanding of how the notions of educational 'inclusion' and 'interculturality' are used in the context of formal education of asylum seeker children in Belgrade.

The argument offered in this paper is that there are two ways to define 'inclusion' in Serbia and that these two ways have to be conceptually divided-the first is inclusion in a narrow sense and the second is inclusion in a wide sense. Inclusion in a narrow sense refers to the context of physical and cognitive disability and implementation of individual education plan (IEP), while inclusion in a wide sense refers also to the context of multi-cultural and multi-lingual diversity in the classroom.

In the introduction, I define the research question and objective and present the structure of the paper. The second part is methodology, where I explain methods behind this research and show who are my informants. In the third part, I discuss literature review, relevant theoretical problems that are connected with my fieldwork and scholary approach to inclusion. Next, I explain the legal context of this research, concerning asylum and Serbia-specific approach to inclusion. In the fifth part, 
I present the results, through answers of my informants and explain the meaning of their answers. In the conclusion, the most important insights are highlighted.

\section{Methodology}

In this anthropological research, case study methodological approach is chosen, combined with ethnographic observation, semi-structured interviews, and literature analysis. The research was conducted in three schools in Belgrade and each school represents one case study. By following an example of similar research from Australia, the first criteria for school selection was their reputation for work with asylum seeker children (Taylor and Sidhu 2012, p. 45). The second criteria for selecting schools was the proximity to Krnjača reception center, where asylum seekers live, and consequently the number of asylum-seeking children enrolled. The third criteria was the 'inclusiveness' of the school. As a result, I visited those three schools and conducted interviews with key support staff.

Data collection was not limited to schools. Interviews with the representatives of the Ministry of Education, Science and Technological Development of Serbia who created and realized the Professional Instruction for Inclusion of Refugee/Asylum Seeking Students in the System of Education and Upbringing were also conducted. From NGO representatives, additional explanations and interpretations of school enrollment process were collected. Also, important insights from parents were gained in Krnjača reception center (see Table 1 "Research Participants").

The focus of the semi-structured interviews with school staff and the representatives of the Ministry of Education, Science and Technological Development were their interpretations of 'inclusion' and their experience of asylum seeker children school enrollment process. The interviews with asylum seeker parents from Krnjača reception center were not conducted for the purpose of this particular paper, but for my $\mathrm{PhD}$ research. However, during interviews, many of my asylum seeker informants talked about this aspect of their family life in Sebia, so I used their insights in this research. I selected only statements of asylum seeker parents whose children go to the schools in which I conducted research for this particular paper.

The limitation of the study which needs to be clarified is that my point of view is shaped by anthropological theoretical methodological frameworks. First, the research topic of this study, social and educational inclusion, is not traditionally explored by anthropologists, but by academics in the field of education science (pedagogy), psychology, defectology, or sociology. Therefore, my interest on certain aspects of this topic comes mainly from the spectrum of theories on cultural diversity and migration. Second, anthropology is a discipline which uses qualitative research methods, so the analysis is focused on research participants' answers, stories, and explanations, instead of quantitative measures. In total, 17 interviews are analyzed in this paper.

Table 1. "Research Participants".

\begin{tabular}{ccc}
\hline Research Participants & Men & Women \\
\hline Number of individual research participants: N =17 & 3 & 14 \\
\hline Teachers (5), school pedagogists (3), school psychologists (1), representatives of the Ministry of Education, \\
Science and Technological Development of Serbia (3), representatives of NGOs (2), asylum seeker parents (3) \\
\hline
\end{tabular}

\section{Discussion: Social Inclusion through Education}

One of the most general ways to think about inclusion is to conceive it as a response to exclusion (Ainscow et al. 2006, p. 15). The marginalization of socially excluded groups and individuals is based on their ethnic, religious, gender, class, or other identity. Social exclusion is often manifested through restricted access to educational opportunities (Forbes and Sime 2016, p. 2). However, "inclusion cannot simply be constructed as the opposite of exclusion", because there is a constant interplay and negotiation between these two processes (Armstrong et al. 2011, p. 36). 
Scholarly approaches to educational inclusion vary among the context of physical disability, cognitive disability (autism, down syndrome, etc.), behavioral and emotional disorders, and multicultural and multi-lingual diversity (Ainscow et al. 2006, p. 15; OECD 2005, p. 14). The goal of formal education of asylum seeker children is to include them into regular classrooms even though they come from different cultural backgrounds and do not speak the native language.

There are three assumptions that prevail in understanding of social inclusion of refugee/asylum seeker children through education in literature. First is that "education might play a role in promoting social cohesion in societies that are increasingly diverse, socially and culturally" (Armstrong et al. 2011, p. 29). The other one is that formal education is supposed to be one of the "protective factors" for refugee and displaced children (Mikuš Kos 2005, p. 16; Farrell 2011, p. 206). The third one is about mental health of refugee children, but many authors oppose to this one, because it tends to reduce refugee children to traumatized subjects. Labeling refugee students as 'traumatised' or 'vulnerable' impedes real analysis of their experiences. By categorising the refugee "as a medicalised subject of trauma" and as "the welfare subject whose survival is reliant on the benevolence of the state" inequalities are masked and prospects for independence reduced (Taylor and Sidhu 2012, pp. 43-44).

In other words, insisting on psychological weakness of refugee children reinforces stereotypes and makes them even more socially isolated. This kind of labeling goes hand in hand with assumption that refugee children need a special treatment in schools because of their vulnerability, which is something that many of my informants emphasized as a difficulty. "Not only that Serbian government provides formal education to migrant children, they are also educating teachers and educators on this topic and how to include migrant children in the informal education" (Stajić 2018, p. 31). Many of my informants went through these training courses, where they were taught that asylum seeker children are 'vulnerable'.

In order to avoid the term 'inclusion', because traditionally it implies some kind of disability, I believe that the term 'inctercultural education' should be used instead, when it comes to cultural and linguistic diversity in classroom. Policy approaches to intercultural education vary from country to country (Catarci 2014, p. 99), but here, the intercultural education is theoretically defined as an approach to education which respects diversity, equity, solidarity, cooperation, and participation, so that all students can achieve their potential and participate in society (Vranješević and Frost 2016, p. 65). Basically, it is a concept similar to inclusion, but instead of 'difficulty', the term 'diversity' is used, since it refers to ethnical/cultural difference. Intercultural education is basically inclusive education for the cultural 'Other'.

There are four levels of integration of multicultural content: the contributions approach, the additive approach, the transformation approach and the social action approach; plan and program for refugee/asylum seeker education in Serbia can be categorized as "the additive approach" (Banks 2010, p. 240). This approach allows the teacher to put content that refers to various ethnic groups in class into curriculum without restructuring it. Planning and programing is the same as for Serbian children, but teachers are organizing extra classes for asylum seeker children so they can follow classes, and they are also trying to stimulate discussions about the cultures to which asylum seekers come from. Also, on school walls I have noticed multilingual inscriptions prescribed in the Professional Instruction for Inclusion of Refugee/Asylum Seeking Students in the System of Education and Upbringing (Stanojković et al. 2017, p. 32). The purpose of these inscriptions is to encourage local children to embrace foreign cultures and languages.

It is noticed that the 'interculturality' of schools depends on their location. In Belgrade's suburban settlements such as Borcha, there are more ethnic minority groups (Roma, Goranci, Albanians, etc.). Ethnic minority groups in Serbia were initially moved to work in industrial sectors, located on the town periphery (Maksin-Mićić 2006). Also, apartments are cheaper in Borcha compared to Belgrade city center, and since many families that are ethnic minorities and immigrants belong to the working class, they are settled in suburban settlements outside the city center. This kind of spatial arrangement is the reflection of power relations between ethnic groups and their roles in the society structure. 
Cities, suburbs, and schools deploy forms of knowledge which further produce and reproduce social relationships and therefore social roles (Forbes and Sime 2016, p. 2).

The difference between 'integration' and 'inclusion' is often a subject of debate in round tables, seminars, classes, and handbooks concerning migration in Serbia. The most frequent explanation is that integration is simply physical presence of excluded groups, and that inclusion means changing values, attitudes, policies, and practices (Polat 2011, p. 50). In terms of education, "the perspective of 'inclusion' generated a critique of special education" (Armstrong et al. 2011, p. 31). OECD classification distinguishes disabilities, learning difficulties and disadvantages, instead of "special educational needs" (OECD 2005). Difficulties and disadvantages are commonly used to describe refugee children's obstacles to education.

The most fruitful approach to inclusion in education is acheived when it is combined with "capability approach", defined by Martha Nussbaum. Her definition of capability approach is an alternative to human rights approach. The practical result of this philosophy is "Education for All" (EFA), a global movement established by UNESCO. The central term of capability approach to inclusion is the idea of social justice (Polat 2011), connected to "individual's ability to proactively participate in politics and society" (Forbes and Sime 2016, p. 5). However, only one of my informants, the representative of an NGO dedicated to economic and social rights, understands inclusion in this way.

The discussions can be simplified to the following formula: multiculturalism versus interculturalism eguals integration versus inclusion. On the one side, there are multiculturalism and integration. These two concepts acknowledge the presence of 'the Other' in society and education, but they are reduced to the physical placement. On the other side, interculturalism and inclusion are more relational concepts. The school psychologist at the 'Jovan Ristić' school explained to me that multiculturalism is when people from different cultures live next to each other, but there are no interactions, while interculturalism is when they communicate and establish relationships. Multiculturalism and interculturalism refer to society in general, while integration and inclusion are discussed in educational sphere. However, the terms 'integration' and 'inclusion' often designate the proccesses of refugee adaptation, not only in schools, but in broader society. This is what produces confusion in contemporary 'inclusion vs. integration' debates-we are not always sure of what inclusion or integration we talk about.

\section{Background: Refugees and Inclusive Education in Belgrade}

Two distinct processes led to inclusion of asylum seeker children in Serbian education system. First is the transition of asylum seeker children from reception into schools. The second one is the transition from the old 'defectology' model and emphasis on 'special needs' to a certain policy on educational inclusion, which on first sight has nothing to do with refugees/migrants/asylum seekers, but it is connected to the way in which educational policies are tailored and in which the term 'inclusion' is understood.

After the so-called long migration summer in 2015 (Milan and Pirro 2018), the presence of migrants from the Middle East and Africa became apparent in Serbia. The formalized corridor established in early summer 2015 enabled refugees to legally cross the Balkans from northern Greece to Western Europe (Beznec et al. 2016, p. 4). The closure of this organized corridor in March 2016 resulted in people being unwillingly stuck in Serbia (Stojić Mitrović 2019, p. 17). Since then, migrants have resided both in informal settlements and state-run reception centers in Belgrade. Migrants who are settled in reception centers in Serbia are categorized as asylum seekers. By September 2017, most of the migrants from Afghanistan, Pakistan, Syria, Iraq, Iran, etc. were in reception and asylum centers, therefore they are called 'asylum seekers' (Lažetić and Jovanović 2018).

Belgrade was not the first town in Serbia in which asylum seeker children were enrolled in elementary schools. The first asylum seeker children were enrolled in 2013, in Bogovađa (Vranješević and Simić 2018, p. 1). In 2014 and 2015 several children were enrolled in the education system, but more systematic inclusion process of asylum seeker children in formal education has officially 
started in August 2016, when the Ministry of Education, Science and Technological Development of the Republic of Serbia sent a letter to school managements to provide the enrollment of asylum seeker children. In May 2017, the Professional Instruction for Inclusion of Refugee/Asylum Seeking Students in the System of Education and Upbringing was issued by the same ministry (Stanojković et al. 2017, pp. 11-12). In Septebmer 2017, almost 700 children from reception and asylum centers in Serbia enrolled in schools (Janković 2017). According to the representative from the Ministry of Education, Science and Technological Development, the education of asylum seeker children was obligatory, but the conditions for that were not provided before September 2017.

Several national and international laws constitute a legal framework for education and inclusion of asylum seeker children. Primary education is mandatory and free in Serbia. A right to education for everyone is guaranteed in the Constitution of The Republic of Serbia, article 71, ${ }^{1}$ in the Serbian Law on Primary Education, article $4,{ }^{2}$ and in the Law on Foundations of Educational System, article $3^{3}$. In order to ensure optimal inclusion of students, according to the Serbian Law on Primary Education, article 64, schools are obliged to remove physical and communication obstacles and insure additional support in education for children who have learning difficulties. In the Law on Asylum and Temporary Protection, article 55 , it is stated that asylum seeker have the right to free primary and secondary education ${ }^{4}$. Other relevant laws and by-laws which institutionalize educational inclusion of asylum seeker children are the Law on Non-Discrimination and Rulebook on more detailed criteria for recognizing forms of discrimination by an employee, child, student or a third person in an educational institution. International legal documents which recommend each child's entitlement to education are Convention on the Rights of the Child, International Convention on the Protection of Rights of Workers and Migrantsand Their Family Members and Salamanca Statement.

Many people think that the distinctive characteristic of educational inclusion in Serbia is the adoption of individual education plan (IEP) (Spasenović and Maksić 2013, p. 212). There are no individual education plans for asylum seeker children, but there is a student support plan (Stanojković et al. 2017, p. 53). The implementation of individual education plan is, therefore, specific for inclusion in narrow sense (related to the context of disability and behavioral disorders), while the implementation of student support plan is specific for expanded meaning of inclusion (related to including asylum seeker children).

Changing both asylum policies and inclusive education policies are among requirements for Serbia's accession to the European Union. Fundamental to the development of asylum and inclusive education policies is compliance with the EU legislative acquis (Macura Milovanović et al. 2014, p. 37). The adoption of inclusive education policies also meant transformation from a 'special needs' to an 'inclusive' approach, which was followed by the closing down of special schools in Serbia. However, a large number of people who work within special education field is being produced. This is because 'defectologists' are graduate-trained in a separate faculty of Belgrade University (Radoman et al. 2006, p. 159). The 'defectology' versus 'inclusion' debate is important for understanding 'inclusion' in narrow sense. Inclusive education is a relatively new concept and sometimes it is considered to be in opposition to the previously established educational practices and policies of special education and defectology.

1 Constitution of the Republic of Serbia. In RS Official Gazette, no. 83/06, 30 September 2006. Available online: https: //www.refworld.org/docid/4b5579202.html (accessed on 9 April 2019).

2 The Law on Primary Education. In RS Official Gazette, no. 55/13, 25 June 2013. Available online: https://erasmusplus.rs/wpcontent/uploads/2015/03/Primary-Education-Law-ENGLESKI.doc (accessed on 9 April 2019).

3 Education for Migrant Students in the Republic of Serbia. The Ministry of Education, Science and Technological Development of the Republic of Serbia, November 2017. Available online: http://www.mpn.gov.rs/wp-content/uploads/2017/11/za-sajtObrazovanje-ucenika-migranata-u-RS-novembar-2017-eng.pdf (accesses on 10 April 2019).

4 The Law on Asylum and Temporary Protection. In RS Official Gazette, no. 24/18, 26 March 2018. Available online: http://www.unhcr.rs/media/docs/2018/LawOnAsylumAndTemporaryProtectionRS.pdf (accessed on 9 April 2019). 
EU accession negotiations are composed of 35 chapters, of which Chapter 23 and Chapter 24 are concerned with migration related issues (Stojić Mitrović 2019, p. 21). Changes in migration and asylum policies were direct results of legal harmonization with EU policies. Asylum law in Serbia exist from 2008-before that, the general public was not concerned with the matter of asylum seekers, refugees and migrants (Stojić Mitrović 2019, p. 19), except in the emigration context (Serbia is more of an emigration than an immigration country).

\section{Results: Inclusive Schools in Belgrade}

In this section, first I will present five steps necessary for asylum seekers' enrollment in schools and explain how these five steps are realized in three schools. Then, I will specify some stories from research participants that tackle the issue of cultural and language diversity. Finally, I will show how school staff and government officials define 'inclusion'.

Selected schools are the examples of refugee inclusion in formal education (Stanojković et al. 2017). The research for this paper was conducted in three elementary schools: 'Jovan Ristić' and 'Rade Drainac' in the Borcha area, and 'Branko Pešić' in the Zemun area. These schools have a reputation for their work with asylum seeker children. All three schools have been involved in pilot projects for refugee and asylum seeker children formal education process, which means that all of them had asylum seeker children in classrooms before the formal start of inclusion policy in September 2017:

First asylum seeker students came in January 2016. That was the first group. They were unaccompanied boys, seven of them. After that, all children were children from the families. We applied to the project by ourselves. (School psychologist, 'Jovan Ristić' school)

We started while it was still a pilot project, in December 2016, it wasn't official yet. We were one of the 10 schools which participated in that project. (School pedagogist, 'Rade Drainac' school)

'Branko Pešić' school also received first asylum seeker students in school year 2016/17. The Professional Instruction for Inclusion of Refugee/Asylum Seeking Students in the System of Education and Upbringing issued by the Ministry of Education, Science and Technological Development is based on the experiences from these schools while they were at pilot project phase. Many text boxes in the handbook for schools in realization of the Professional Instruction (Stanojković et al. 2017) contain stories from these three schools.

The Professional Instruction for Inclusion of Refugee/Asylum Seeking Students in the System of Education and Upbringing defines steps necessary for enrollment and monitoring process. ${ }^{5}$ The first step is to submit a request for enrollment. This should be done by a parent or a guardian, or social worker, if the child is unaccompanied. In practice, asylum seeker parents rarely come to school and submit a request by themselves. Instead, school staff sends a translated form through NGO staff (mainly farsi or arabic interpreters, who help children in schools) to a reception center, which parents sign and send back to school. Humanitarian worker who accompanies asylum seeker children from reception center to school said that it was not easy to persuade some parents to enroll their daughters in schools:

There are also girls. That is the biggest difference between their school and our school. We put a lot of effort to convince some parents of girls to enroll them in school. It is a big success for them, that they let the girls to go to the same school as boys from Afghanistan... Because there, they are separated. They either go to separated schools or to different shifts in

5 The Ministry of Education, Science and Technological Development of the Republic of Serbia. 2017. Professional Instruction for Inclusion of Refugee/Asylum Seeking Students in the System of Education and Upbringing. Available in Serbian at: http://www.mpn.gov.rs/strucno-uputstvo-za-ukljucivanje-ucenika-izbeglicatrazilaca-azila-u-sistem-obrazovanja-ivaspitanja/ (accessed on 9 April 2019). 
the same school. One shift only girls, other shift only boys. (Humanitarian worker, Danish Refugee Council)

Before the interview with humanitarian worker from DRC, I was not fully aware of the fact that children are separated by gender in schools in Afghanistan. Her statement helped me to understand why one father that I interviewed was so worried about his daughter's wellbeing in schools. He told me that his daughter (17) stopped going to school. I asked what was the problem, and he said "Serbian guys no problem. All problem is another single guys Afghani and Pakistani" (Asylum seeker from Afghanistan, 41). The inclusion in Serbian schools, where it is normal that boys and girls go to same classes, means that parents and children need to adapt themselves to different cultural norms. In other research, it is suggested that "migrant childred think that schools in Serbia differ from the ones they had attended in the countries they had come from because there is no corporal punishment and, notably, the rights of the child and their opinions are respected" (Vranješević and Simić 2018, p. 6).

Besides the signed form, parents need to show a certificate on registration from police and health report from doctor in reception center. Next, an expert team in the school should make the plan of support. The third step is the assessment of previous knowledge. This step is crucial for deciding in which grade the asylum seeker child will be enrolled. Sometimes it is hard to determine the grade:

There are two difficulties that asylum seeker children need support for: language and holes in knowledge... Because some of them didn't go to school at all, some of them went inordinately, some of them went to informal schools... And different things are being taught there. So they need tailored program, so they can understand, but also this new knowledge should lean on their previous knowledge. So, in that sense, this is similar to inclusion (i.e. inclusion in narrow sense). But at the end, the biggest problem is language. (School psychologist, 'Jovan Ristić' school)

Fourth, the plan of support is elaborated in more detail. The final step is monitoring and documenting in order to make a portifolio in English, which serves as certificate that asylum seekers show to schools in destination countries. The purpose of the certificate is to provide a proof that children were going to school during their journey to destination country.

Education plays important role not only for asylum seeker children, but also for their parents. The school pedagogist from 'Rade Drainac' and school psychologist from 'Jovan Ristić' both said that they have experience with asylum seeker families which think that education is very important and who put an extra effort. NGO ADRA Community Centre in Borcha organizes extra classes for children from Krnjača reception center and helps them to do homework. An asylum seeker from Krnjača reception center, whose children went to 'Rade Drainac' school, emphasized the importance of education:

I am an educated person, I have university degree. I am already 40+, I don't want more. My time is over, partially. But my children need to have good education, in Europe. I have friends and family there. They will help me with my children's education ... My children like school here, they go every day, without any delay ... And they have learned a lot. Especially my small children. All of them have talent. For all subjects, especially mathematics, English, physics. They are good ... We have 12 grades in Afghanistan. My daughter is going to ADRA school, she only finished 10 grades in Afghanistan. My baby son learned a lot of Serbian ... And he knows English. Some of his classmates don't know English ... So he taught them English and they taught him Serbian! (Asylum seeker from Afghanistan, 45)

In order to explore characteristics of schools with inclusive programs in Belgrade in regard to cultural diversity, we must look beyond the education of asylum seekers and ask about other particular groups. In 'Jovan Ristić' school, there are around 80 students of Gorani people ethnic minority. 'Rade Drainac' is a school where there are five Roma children per class: 
There are a lot of Roma students in our school. But Roma students mostly know Serbian language. So, it isn't the same. It isn't even similar. Simply, you get children who at the moment of their arrival don't know a single word in Serbian. (School pedagogist, 'Rade Drainac' school)

Special pedagogist in 'Branko Pešić' said that the school is not specialized for any particular group, but by observing the school, it was obvious that almost all students in school are Roma. I had an informal conversation with several Roma boys in front of the 'Branko Pešić' school. Some of them are not fluent in Serbian language, because they lived in Germany and Austria for most of their lives and now they are back in Serbia due to EU readmission agreement. Lack of competence in Serbian makes it difficult for Roma children to do well in school (Filipović et al. 2010, p. 263), so they are also subjects of educational inclusion policies. Regarding the 'inclusiveness' of this school, special pedagogist said that:

All children all included here ... Everybody have some difficulties in functioning in some aspect of life ... It might be learning difficulty, behavior problem, communication difficulty, physical disability ... Here we have children with one kind of problem and children with other kind of problem. (Special pedagogist, "Branko Pešić" school)

'Branko Pešić' school is the only school in this research that has a special pedagogist employed. A special pedagogist is a person who has a degree of the Faculty for Special Education and Rehabilitation and who is trained to work with children with difficulties and disadvantages. This school is different than other two included in this research. All asylum seeker children who go to 'Branko Pešić' school are 14+ years old, which means that asylum seeker children who are enrolled in this school are the who are too old for primary school. Cultural differences in terms of education, documented in this research, unquestionably influence on of asylum seekers' perception on schools in Belgrade. These differences are the structure of education system (e.g., the grades in primary school), gender stratification (e.g., girls and boys do not go together in school), subjects in schools (e.g., 'holes' in knowledge), and language (e.g., the 'language barrier'). Generally, the employees in these schools share similar values, related to inclusion, tolerance, and multicultural education. All of them praised asylum seeker children for their fast learning of Serbian language. They all said that at the beginning there were some minor incidents (e.g., between asylum seekers and Roma children), but that now everything goes fine. The conflict between cultural relativism and inclusiveness can be perceived as a reflection of a wider opposition between particular and universal, which is an important debate when it comes to policies of cultural diversity.

I asked almost all of research participants what is 'inclusion' for them, and the answers were different. Lots of them used descriptive definitions of inclusion, which describe "the variety of ways 'inclusion' is used in practice" (Ainscow et al. 2006, p. 14). This is actually just defining 'inclusion' through examples from immediate surroundings. Typical way in which my informants defined inclusion through examples is "they are very well accepted by their school mates, e.g., yesterday they have been doing their homework together". However, some unexpected examples of what inclusion may have emerged:

In German school in Belgrade where I also teach, 'inclusion' doesn't refer to foreigners ...

But, for example, there are children who need additional support because they are neglected.

This phenomenon is called 'Wohlstandsverwahrlosung' ... It is used for rich people's children,

who because of neglection and emotional emptiness have issues. They grew up with nannies.

They also need to be 'included'. (German teacher)

Prescriptive definitions, on the other hand, tend to find common patterns among various practices and provide theoretical comprehension of inclusion. Only three of my informants defined 'inclusion' in general. All three definitions emphasize the agency of the education system and view inclusion through the lens of educational policies, which are the top-down definitions of inclusion: 
Inclusion is the principle to enroll a child into prescripted education plan and program, while taking care about him the way he is. (School psychologist, 'Jovan Ristić' school)

Integration is when you adapt to the system, and inclusion is when the system adapts to you.

(The leader of the Group for Education of Minorities, Social Inclusion and Protection from violence and Discrimination in the Ministry of Education, Science and Technological Development of the Republic of Serbia)

Inclusion is having a possibility to access an education in an environment which makes it under pressure. (German teacher)

Finally, almost all of my informants emphasized the 'transit' character of asylum seekers' presence in Serbia. Serbia's status as a transit country may be the main reason why it is not necessary that asylum seeker children must learn the Serbian language before they enroll in schools. There is no need to put the effort into learning the language, because it is assumed that no asylum seeker want to stay in Serbia. Previous research has shown that most of the asylum seekers do not see their future in Serbia (Lažetić and Jovanović 2018, p. 18). Regardless, children are speaking Serbian, due to their long stay.

In Germany, they must learn the language first. That is called integration. Unlike that, "we in Serbia" give them an opportunity to go to school right away. Here, we put them in regular schools right away, even though they don't speak our language. That is inclusion.

(The leader of the Group for Education of Minorities, Social Inclusion and Protection from violence and Discrimination in the Ministry of Education, Science and Technological Development of the Republic of Serbia; the doctor of psychology)

Therefore, learning of native language as a precondition for school enrollment appears to be one more criteria for the distinction between 'inclusion' and 'integration'. According to this viewpoint, knowing the host's language is necessary for integration, while inclusion is less demanding and more sensitive toward cultural diversity.

\section{Conclusions}

Five important points arose from this research. First, inclusion in Serbia can be defined in narrow and in wide sense. Inclusion in narrow sense is when children with physical, cognitive, emotional, or behavioral disorders are included in school classrooms and when indivudual education plan (IEP) is practiced, in order to help them to overcome the difficulties. Inclusion in wide sense is when children from different cultural and linguistic backgrounds are included in classrooms. Second, when we talk about asylum seeker children, the term 'intercultural education' is more appropriate than the term 'inclusion', precisely because of the confusion that may arise from the first point. Third, other categories of children who need additional support in education, such as Roma children, sometimes overlap with asylum seekers in terms of education policies. Forth, asylum seeker children are not obliged to learn the Serbian language before they enroll in schools, because most of the asylum seeker families do not see their future in Serbia, but most of the children do learn it eventually, because they are surrounded by other children who speak Serbian all the time. Fifth, inclusion of asylum seeker children in schools is the most developed and the most positive aspect of refugee integration in Serbia.

Serbia adopted both asylum policies and inclusive education policies in order to access the EU. By including asylum seekers in elementary schools, Serbian government tends to affirm its competency to adapt to European laws and values. The official attitude of Republic of Serbia is that inclusion of refugee/asylum seeker children presents a fundamental aspect of asylum seeker's integration into Serbian society. It is more likely that asylum seeker children's enrollment in school is the only aspect of de facto refugee integration. However, in the Serbian context in 2019, 'integration' is just another word for 'accepting' or 'be kind to people in trouble'. There are no real integration policies. Asylum 
seekers get the job permit if they enter into asylum proceedure and after nine months spent in Serbia, so their possibilities to get a job are very limited. Also, asylum seekers are living in reception centers. The prospects for refugee/asylum seeker integration into Serbian society are very low. Asylum seekers, state officials, school staff and NGO staff stick to the attitude that Serbia is a transit country, even though there are no legal ways for asylum seekers to actually leave the country and move on.

However, this research shows that asylum seekers going to elementary school every day is a very positive process. The most of the asylum seekers and school staff are satisfied with this situation. It helps the children to have a more quality time in Serbia, while they wait to go further. It also helps them to feel normal. All people interviewed for the purpose of this paper perceive inclusion as the readiness of themselves and the state to accept asylum seeker children into their everyday lives. The values added to this notion are tolerance, kindness, solidarity, and hospitality. However, it is very unlikely that educational inclusion is sufficient for asylum seeker's equal participation in society.

Funding: This research received no external funding.

Conflicts of Interest: The author declare no conflict of interest.

\section{References}

Ainscow, Mel, Tony Booth, and Alan Dyson. 2006. Improving Schools, Developing Inclusion. London and New York: Routledge.

Armstrong, Derrick, Ann Cheryl Armstrong, and Ilektra Spandagou. 2011. Inclusion: By choice or by chance? International Journal of Inclusive Education 15: 29-39. [CrossRef]

Banks, James A. 2010. Approaches to multicultural curriculum reform. In Multicultural Education: Issues and Perspectives. Edited by James A. Banks and Cherry A. McGee Banks. Danvers: John Wiley, pp. $233-58$.

Beznec, Barbara, Marc Speer, and Marta Stojić Mitrović. 2016. Governing the Balkan Route: Macedonia, Serbia and the European Border Regime. Belgrade: Rosa Luxemburg Stiftung Southeast Europe, ISBN 978-86-88745-21-5.

Catarci, Marco. 2014. Intercultural education in the European context: Key remarks from a comparative study. Intercultural Education 25: 95-104. [CrossRef]

Farrell, Ann. 2011. Transnational Displacement of Children: An Australian Perspective. In Global Migration and Education: Schools, Children and Families, 2nd ed. Edited by Leah D. Adams and Anna Kirova. Abingdon: Routledge, pp. 203-18, ISBN 0805858385.

Filipović, Jelena, Julijana Vučo, and Ljiljana Djurić. 2010. From language barriers to social capital: Serbian as the language of education for Romani children. In Selected Proceedings of the 2008 Second Language. Research Forum. Edited by Matthew T. Prior, Yukiko Watanabe and Sang-Ki Lee. Somerville: Cascadilla Proceedings Project, pp. 261-75, ISBN 978-1-57473-439-3.

Forbes, Joan, and Daniela Sime. 2016. Relations between Child Poverty and New Migrant Child Status, Academic Attainment and Social Participation: Insights Using Social Capital Theory. Education Sciences 6: 24. [CrossRef]

Janković, Marija. 2017. Serbia's Child Migrants Find Road to School Long. Balkan Insight. September. Available online: https://balkaninsight.com/2017/09/27/serbia-s-child-migrants-find-road-to-school-long-09-26-2017/ (accessed on 8 April 2019).

Lažetić, Marina, and Teodora Jovanović. 2018. Belgrade, Serbia: A Case Study of Refugees in Towns. Refugees in Towns Project. Boston: Feinstein International Center, Friedman School of Nutrition Science and Policy at Tufts University, Available online: https://static1.squarespace.com/static/599720dc59cc68c3683049bc/t/ 5ace0dd4f950b79e5858d6a9/1523453398380/Tufts+RIT+Belgrade\%2C+Serbia.pdf (accessed on 10 April 2019).

Macura Milovanović, Sunčica, Ivana Batarelo Kokić, Selma Džemidžić Kristiansen, Ibolya Gera, Estevan Ikonomi, Lejla Kafedžić, Tamara Milić, Xhavit Rexhaj, Ognen Spasovski, and Alison Closs. 2014. Dearth of early education experience: A significant barrier to educational and social inclusion in the Western Balkans. International Journal of Inclusive Education 18: 36-54. [CrossRef]

Maksin-Mićić, Marija. 2006. Peripheral zones of Serbian towns: Spatial development and way of life. Ethnologia Balkanica 10: 35-58.

Mikuš Kos, Anica. 2005. Activating Community Resources for the Well Being of Children and Stability. In Promoting the Psychosocial Well Being of Children Following War and Terrorism. Edited by Matthew J. Friedman and Anica Mikus-Kos. Amsterdam: IOS Press, pp. 11-32, ISSN 1574-5597. 
Milan, Chiara, and Andrea LP Pirro. 2018. Interwoven Destinies in the 'Long Migration Summer': Solidarity Movements Along the Western Balkan Route. In Solidarity Mobilizations in the 'Refugee Crisis'. Edited by Donatella della Porta. Basingstoke: Palgrave Macmillan, pp. 125-53. [CrossRef]

OECD. 2005. Students with Disabilities, Learning Difficulties and Disadvantages: Statistics and Indicators. Paris: Organisation for Economic Co-operation and Development, ISBN 92-64-00980-9. No. 539932005.

Polat, Filiz. 2011. Inclusion in education: A step towards social justice. International Journal of Educational Development 31: 50-58. [CrossRef]

Radoman, Vesna, Virxhil Nano, and Alison Closs. 2006. Prospects for inclusive education in European countries emerging from economic and other trauma: Serbia and Albania. European Journal of Special Needs Education 21: 151-66. [CrossRef]

Spasenović, Vera, and Slavica Maksić. 2013. Challenges of Democratisation: Development of Inclusive Education in Serbia. In Education in One World: Perspectives from Different Nations. Edited by Nikolay Popov. Sofia: Bulgarian Comparative Education Society, pp. 209-15, ISBN 978-954-92908-3-7.

Stajić, Jovana. 2018. Comparative Analysis of Migrant Integration through Education in Serbia and Turkey. Master's thesis, University of Belgrade, Faculty of Political Sciences, Regional Master's Program in Peace Studies, Belgrade, Serbia, September.

Stanojković, Darko, Ljiljana Panjković, Marina Todić, Ljiljana Arbutina, Tanja Ranković, Ivana Cenerić, Žaklina Veselinović, Jasminka Čekić Marković, Ana Vušurović Lazarević, Dr Snežana Vuković, and et al. 2017. Priručnik za škole u realizaciji stručnog uputstva za uključivanje učenika izbeglica/tražilaca azila u sistem obrazovanja i vaspitanja. Beograd: Ministarstvo prosvete, nauke i tehnološkog razvoja, ISBN 9788674520680. Available online: http://www.cep.edu.rs/public/Realizacija_Programa_dobrodoslice_ucenicima_migrantima. pdf (accessed on 9 April 2019). (In Serbian)

Stojić Mitrović, Marta. 2019. The Reception of Migrants in Serbia: Policies, Practices, and Concepts. Journal of Human Rights and Social Work 4: 17-27. [CrossRef]

Taylor, Sandra, and Ravinder Kaur Sidhu. 2012. Supporting refugee students in schools: What constitutes inclusive education? International Journal of Inclusive Education 16: 39-56. [CrossRef]

Vranješević, Jelena, and David Frost. 2016. Stories From Intercultural Education in Serbia: Teacher Leadership and Parent Participation. European Education 48: 63-78. [CrossRef]

Vranješević, Jelena, and Nataša Simić. 2018. Safe and Enabling Elementaty Education Environment for Refugee and Asylum Seeking Pupils. Belgrade: Save the Children, Available online: https://resourcecentre.savethechildren.net/sites/ default/files/documents/safe_and_enabling_school_environment_for_refugee_and_asylum_seeking_children_ in_serbia_research_summary_web.pdf (accessed on 21 April 2019).

(C) 2019 by the author. Licensee MDPI, Basel, Switzerland. This article is an open access article distributed under the terms and conditions of the Creative Commons Attribution (CC BY) license (http://creativecommons.org/licenses/by/4.0/). 
Article

\title{
The Asylum Seekers in Non-Metropolitan Areas in France: Between Temporary Integration and Leading to Autonomy. The Case of the Ambertois Territory
}

\author{
Rafik Arfaoui \\ Université Clermont Auvergne, AgroParisTech, Inra, Irstea, VetAgro Sup, Territoires, \\ F-63000 Clermont-Ferrand, France; mohammed_rafik.arfaoui@uca.fr
}

Received: 19 April 2019; Accepted: 4 July 2019; Published: 5 July 2019

\begin{abstract}
This article focuses on the integration process of people seeking asylum in non-metropolitan areas in France. It conceptualizes the reception of asylum seekers involving two interrelated approaches: the utilitarian approach and the humanitarian approach. This article is based on surveys, participatory and sensitive cartography, and participant observation conducted in the Ambertois territory between 2017 and 2018. I find the Ambertois territory can be considered a "fragile space," particularly in terms of demographics, with difficulties in maintaining public services. These difficulties are risks for asylum seekers, and are impacting the urban space. These risks are intensified by the national and regional level policies like the recent reform of the asylum and immigration act on the one hand, and the suffering they experienced throughout their migratory journey on the other. Faced with these risks, local synergies, which facilitate the integration of asylum seekers, are emerging from local actors. This integration is temporary and is considered by local actors as leading to the autonomy of asylum seekers.
\end{abstract}

Keywords: asylum seekers; non-metropolitan areas; fragile spaces; temporary integration; autonomy; dispersal policy; France

\section{Introduction}

The Ambertois territory within the Puy-de-Dôme in the Auvergne-Rhône-Alpes region provides an example of the settlement of asylum seekers in central France (see Figure 1). This settlement operation has been conducted since July 2016. In this operation, four municipalities (Ambert, Arlanc, Cunlhat, and Saint-Amant-Roche-Savine) coordinated together to create a reception center for asylum seekers. The settlement operation is part of a wider national dispersal policy for migrants conducted in France since July 2015. ${ }^{1}$ Some of these reception centers have been created in non-metropolitan areas because of their relatively low cost compared to other, more expensive parts of France. However, while the housing availability and cost is lower in these non-metropolitan areas, the commitment of local actors to host asylum seekers on their territory may not be as strong as metropolitan areas. The reception center for asylum seekers in the Ambertois territory contains apartments located in different sites in the four municipalities. The lives of the asylum seekers I spoke with were punctuated by administrative and medical appointments, encounters with neighbors, and feelings of solitude. Encounters with neighbors allowed them to escape the solitude of their living arrangements. Volunteers

1 The dispersal policy refers here to the asylum reform introduced in France on 29 July 2015. It aims to resettle migrants, who live in Paris and around Calais in particular, to other parts of France, through the National Reception System (DIspositif National d'Accueil). Thus, asylum seekers cannot decide where they will stay. The French state decides where they will be housed. For more information: https://www.immigration.interieur.gouv.fr/Asile/La-reforme-de-l-asile-issue-de-la-loi-du29-juillet-2015/Loi-n-2015-925-du-29-juillet-2015-relative-a-la-reforme-du-droit-d-asile. 
provided activities that responded to some of the needs of asylum seekers and reduced the risks they faced from a restrictive asylum policy and the "fragile space" that Ambertois provides for integration.

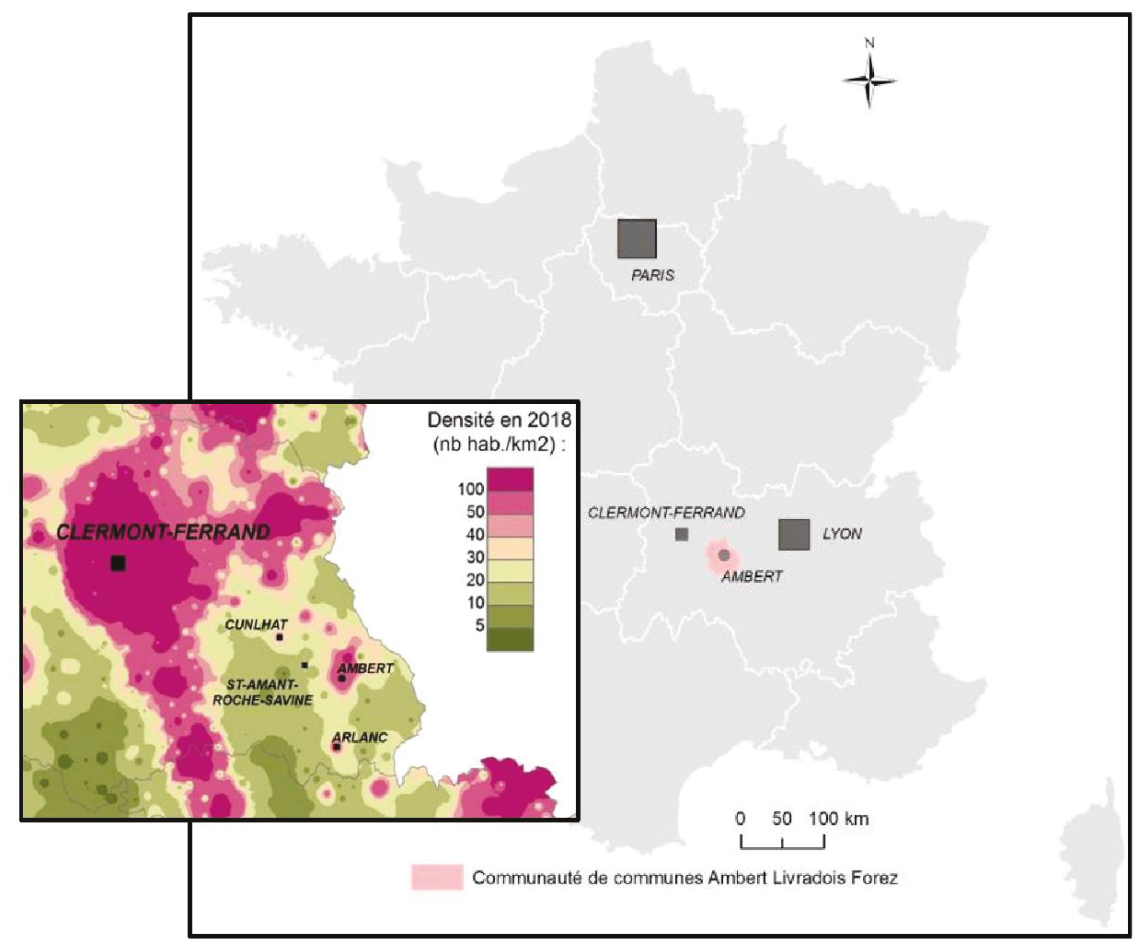

Figure 1. The Ambertois territory. Source: Rafik Arfaoui, INSEE data base, 2018.

In this article, I will first explain the dispersal policy of migrants in France and the resettlement system for asylum seekers, particularly in non-metropolitan areas. Following this, I will present how the Ambertois territory can be considered a fragile space. Finally, I will discuss the urban impact of asylum seekers, and their experiences in the Ambertois territory. The analysis of urban impacts reveals two interrelated approaches in the Ambertois territory: the utilitarian approach and the humanitarian approach. The analysis of asylum seekers' experiences reveals that their integration involves developing autonomy by building local connections that respond to real risks.

\section{Methods}

My research focused on the reception of asylum seekers in non-metropolitan areas. I chose this area because the geography literature on asylum seekers in France has often focused on large cities, but little research has been done on non-metropolitan areas (CAMIGRI 2016). Since 2015, non-metropolitan areas have become increasingly important in migration studies. In addition to my thesis, I can also mention the "Camigri" project (Les campagnes françaises dans la dynamique des migrations internationales), which aims to analyze the settlement of migrants in rural areas in France.

This article is based on field surveys conducted between 2017 and 2018. First, I identified the actors involved in the reception and integration of asylum seekers: Institutional and associative actors, ${ }^{2}$

2 I define institutional actors as mayors and governmental officials. Associative actors include the directors of the reception center for asylum seekers, humanitarian organizations, and social workers. 
volunteers and displaced persons' support groups, and asylum seekers themselves (See Figure 2, Tables 1 and 2). For my key informant interviews, I used semi-structured interviews, each lasted between $45 \mathrm{~min}$ and $2 \mathrm{~h}$.

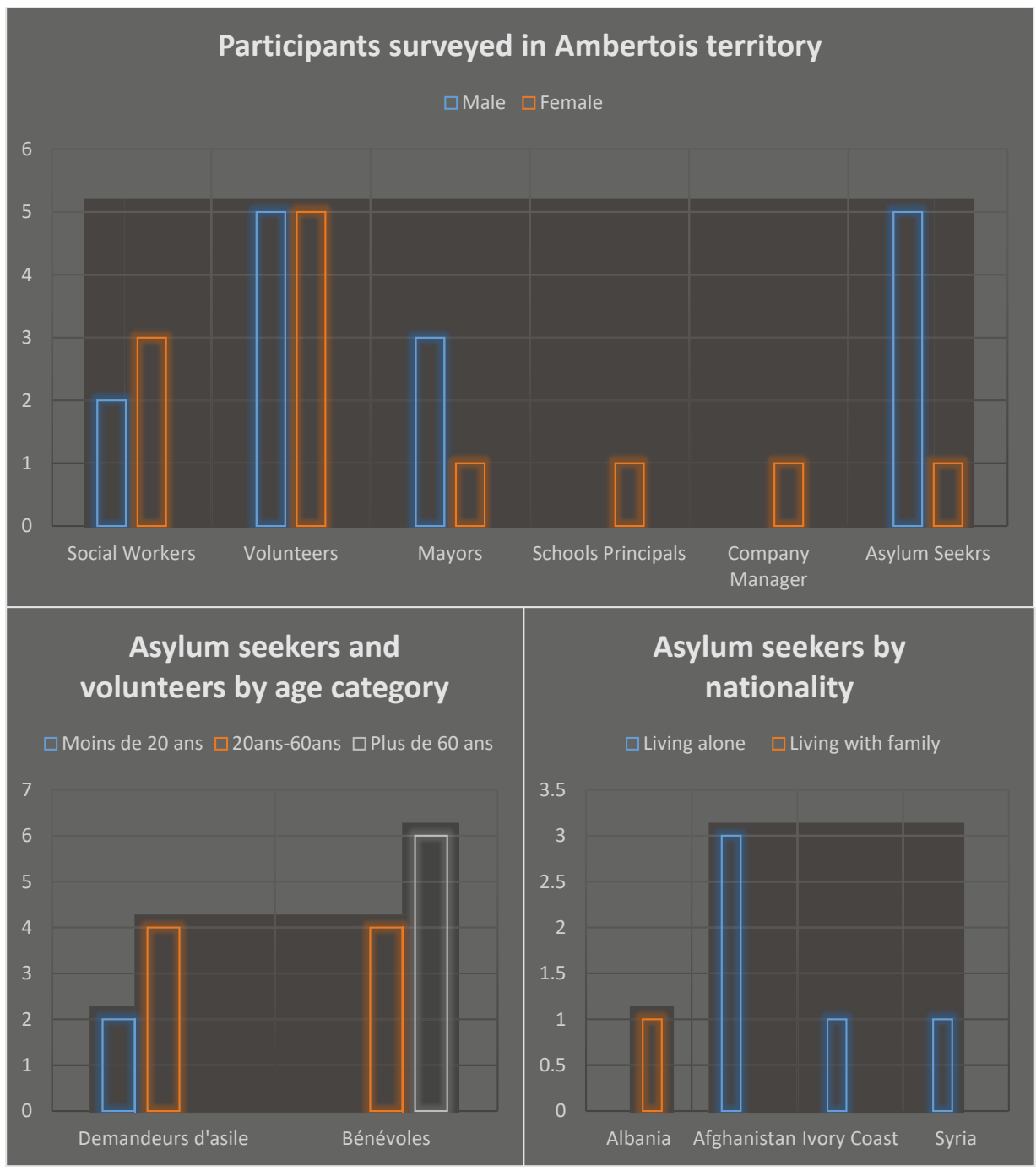

Figure 2. The participants surveyed in the Ambertois territory. Source: Rafik Arfaoui, field research data base, 2017 to 2018 . 
Table 1. The participants by their title, category, and institution. Source: Rafik Arfaoui, field research data base, 2017 to 2018 .

\begin{tabular}{ccc}
\hline Institution & Category & Title of Participant \\
\hline Elementary School & Educational Institution & Principal \\
Samwill Company & Industrial Company & Manager \\
Municipality of Ambert & Municipal Government & Councilor' Municipality \\
Municipality of Arlanc & Municipal Government & Mayor \\
Municipality of Cunlhat & Municipal Government & Mayor \\
Municipality of Saint-Amant-Roche-Savine & Municipal Government & Mayor \\
Collectifl'Élégante & Non-governmental Organization & Volunteers \\
Not related in any Institution & Volunteers \\
Reception center for asylum seekers & Humanitarian Organization & Social Workers \\
\hline
\end{tabular}

Table 2. The asylum seekers surveyed by age, sex, and family situation. Source: Rafik Arfaoui, field research data base, 2017 to 2018.

\begin{tabular}{cccc}
\hline Nationality & Age & Sex & Family Situation \\
\hline Ivory Coast & 19 & Female & Living alone \\
Albania & 40 & Male & Living with 2 children and his wife \\
Afghanistan & 27 & Male & Living alone \\
Afghanistan & 20 & Male & Living alone \\
Afghanistan & 30 & Male & Living alone \\
Syria & 29 & Male & Living alone \\
\hline
\end{tabular}

I chose to use participatory and sensitive cartography with participants because it offered a method for narrative decentralization (Mekdjian et al. 2014). Forms of visual expression, and not only discursive, appear through "cartographic gestures" (Mekdjian and Olmedo 2016). In other words, cartography goes beyond the constraints of the face-to-face discursive engagement. It conveys forms of symbolic violence, produced in particular by the administrations in charge of examining asylum applications in France. To accept an asylum application, these administrations interrogate asylum seekers about their life story in order to find elements to justify protection. This is done in a context of suspicion of "fake refugees." Our approach was partly of a reflection on the researcher's ethics, and a rethinking of the cartographic production method in geography by moving from a top-down model to a bottom-up model.

To this end, I organized cartography workshops involving asylum seekers living in the Ambertois territory. There were six participants, including one woman, aged between 19 and 40 years old. They were not paid for their participation. Contact with the participants was established through the coordinator of the reception center where they were housed. The participants spoke Arabic, French, English, and Dari. My ability to speak three of the four languages built a climate of trust and facilitated the exchange. For those who spoke Dari, one of the Afghan participants who also spoke English acted as a translator.

I explained to the participants that I do not belong to the reception center administration, but that I am a PhD student at the University of Clermont Auvergne. I introduced myself as an Algerian immigrant who came to France to study geography. This reinforced the climate of trust. At the same time, it raised questions of injustice (Young 1990) related to inequalities in freedom of movement and residence according to the administrative status of migrants. All these aspects were taken into consideration in the analysis of the maps produced by the participants.

The first step of the workshop was to co-create a key of their journey (see Figure 3). This key translated the co-production of a collective narrative about migration from individual experiences. To do this, first, all participants attached sticky notes that described their experiences of the trip. Then, participants grouped these sticky notes and created keyword categories. Finally, a visual representation was created using stickers in different colors and shapes. 


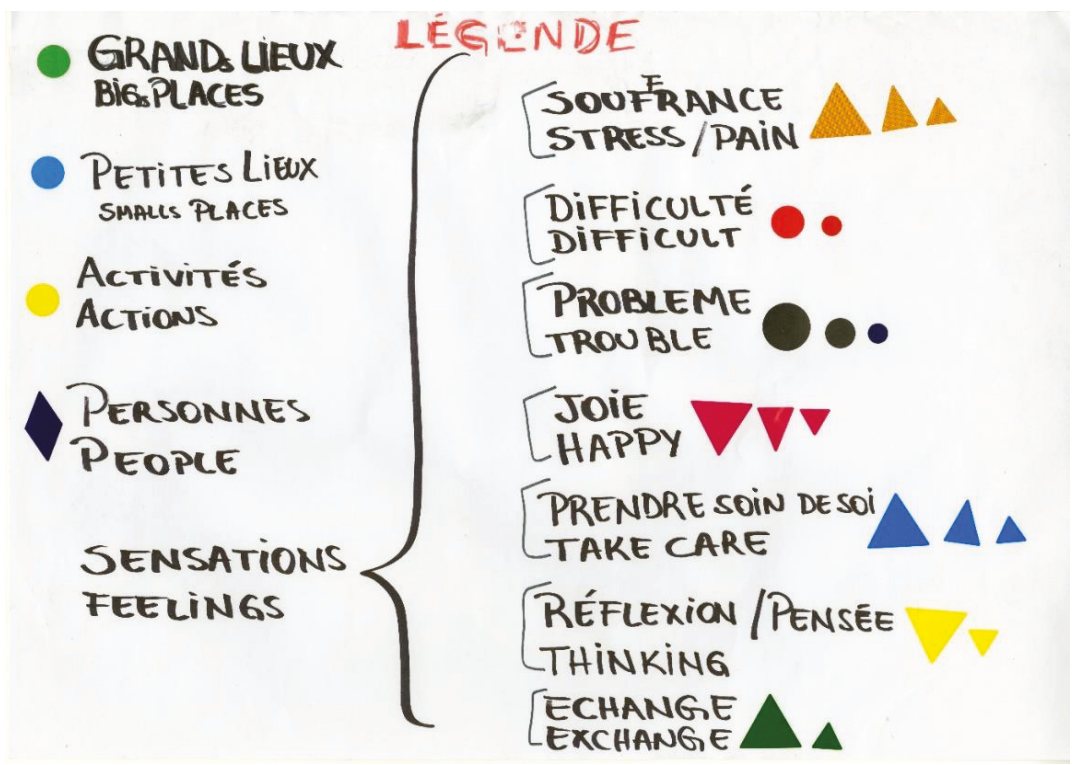

Figure 3. Collective key on the exile experience of asylum seekers hosted in the Ambertois territory. Source: Rafik Arfaoui and participants of workshops, July to August 2017.

\section{Background of Reception of Asylum Seekers}

Since 2015, the French government has been using a new asylum and immigration act, which aims to disperse exiles from the concentration areas (Paris and the area around Calais) to other parts of the country. Land opportunities and the relatively low cost of reception, and the desire of local politicians, have placed non-metropolitan areas at the heart of the national dispersal policy. For this reason, many reception centers have been created. This dispersal policy is multi scalar and it can be found at European, national, and local levels (see Figure 4).

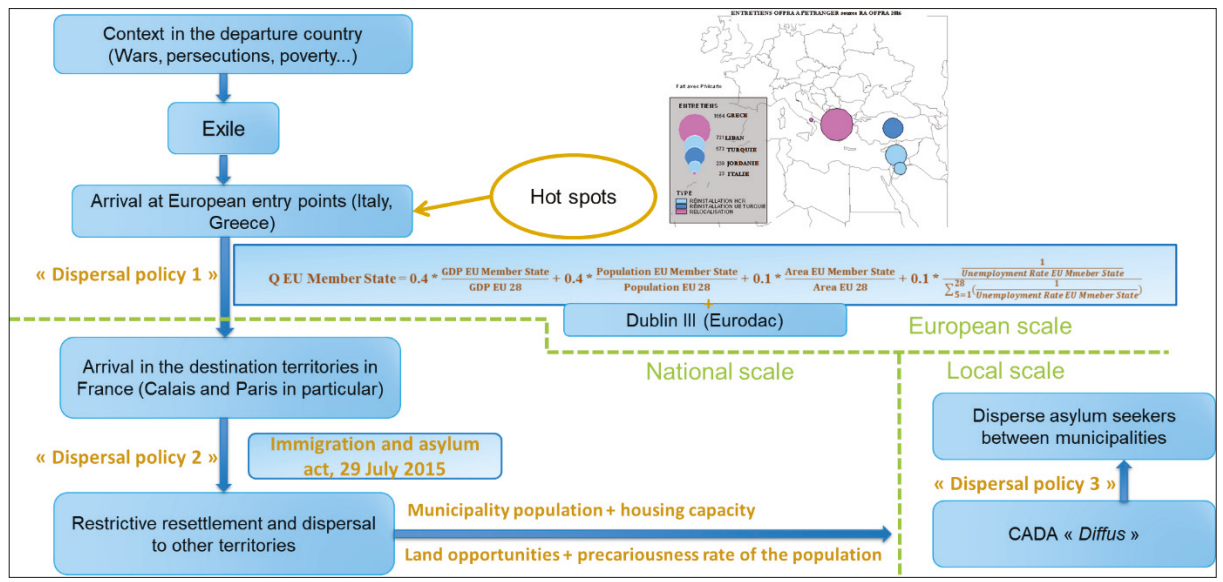

Figure 4. Multi-scalar dispersal of exiles' policy. Source: Knowledge of migration policies, Rafik Arfaoui, 2017. 


\subsection{On Ambertois Territory}

Once they have arrived in the reception areas, people seeking asylum are, in some cases, dispersed many times. Since 2016, a new category of accommodation for asylum seekers has been introduced, known as a diffused reception center. The idea is that people are hosted on different sites and often in several municipalities. Several municipalities then network with the aim to create a "fair" distribution of the number of asylum seekers. This is the case in the Ambertois territory where asylum seekers are resettled in four municipalities: Ambert, Arlanc, Cunlhat, and Saint-Amant-Roche-Savine. This suggests that inhabitants, institutional actors, and associative actors have little perspective on the issue of reception and integration. This temporality dimension has been taken into account in my analysis.

\subsection{On France}

Since the end of the 18th century, France has proclaimed the constitutional right of asylum. In article 120 of the 1793 Constitution, "the French people give asylum to foreigners banished from their homeland for the cause of freedom. He denies it to tyrants." Even if it will not be applied, this article places the reflection on asylum in France in a tradition that goes back more than two centuries. Since the 1951 Geneva Convention and the 1969 New York Protocol, France has granted asylum to persons considered "at risk" in their country of origin. The protection rates of asylum seekers have changed significantly since the 1970s. Indeed, the OFPRA (Office Français de Protection des Réfugiés et des Apatrides), which granted refugee status to $85 \%$ of exiles seeking asylum in 1973 , refused it to $85 \%$ of them in 1990.

The French State introduced a new immigration and asylum act on 29 July 2015. The areas known as "migrant camps", particularly in Paris and Calais, have been highly publicized. The government's intention was, in addition to protecting the exiles, to "make them invisible." To this aim, persons wishing to be accommodated in reception centers for asylum seekers no longer had the possibility to choose their residence area. They were forced to accept the proposed accommodation at the risk of losing their right to the Asylum Seekers' Allowance. Thus, several asylum seekers found themselves in areas they had not chosen. The creation of reception centers had to meet four criteria: The size of the municipality population, accommodation capacity, land opportunities, and the precariousness of the population.

\subsection{On the EU}

On a European scale, there are dispersal policies through so-called "relocation" operations. These operations aim to distribute people seeking asylum from hot spots (Greece, Turkey, Jordan, and Lebanon). These hot spots aim to identify people seeking asylum and to remove undesirables (Agier 2008). This eviction is part of an approach to asylum that distinguishes "real" refugees from "fake" refugees. The distribution policy from hot spots is based on the observation that each European country must take its share of "responsibility" for the reception of asylum seekers. This distribution is a reminder of the measure proposed by Jean-Claude Junker to "distribute" asylum seekers among the 28 EU Member States. Four indicators were taken into consideration to calculate each country's quota: Population size, country area, gross domestic product (GDP), and unemployment rate (Schneider et al. 2013). Another example of the dispersal policy in the EU is the Dublin II and III regulations. These regulations imply that asylum seekers must do so in the country where their fingerprints were first taken. Verifications are carried out via the Eurodac data system. If an EU State, where the person is seeking asylum, finds that a fingerprint has previously been taken in another EU country, then a removal procedure is initiated to that country. People are identified as "Dubliners". This forced displacement measure is produced in a spirit of "burden sharing". The idea of burden refers more broadly to a perception of exiles by host States as a "burden" to be supported. Following this analysis, two questions became important: Has the process of resettlement brought something positive? Has it made facilitated the integration of asylum seekers? 


\section{Data and Findings}

\subsection{The Ambertois Territory: A Fragile Space}

Fragile space is a theme that appeared in human geography around 1985. Like other themes that emerged before or after this period, such as "espaces défavorisés" 3 or "territoires sensibles," 4 it describes situations of "crisis" facing spaces. For the definition of fragile spaces, Laurent Rieutort (2006) underlines the idea of zones "prêtes à se briser" (Rieutort 2006, p. 15). The concept of fragile space is therefore associated with the dimension of the risk of worsening the situation of a space. It may be related to its demographic, social, and economic dynamics in relation to national and regional averages or to an average specific to the space object under study (Edouard 2017).

First, there are demographic indicators. The statistical indicators concerning the average annual rate of change in the population between 2010 and 2015 highlight that the four municipalities where the reception center is located were losing population (see Table 3). Of course, the dynamics are more complex when we look at the details of this demographic evolution, between migratory changes and the rate of natural increase. However, there needs to be a minimum number of people within a geographic area to keep public facilities (schools, hospitals, etc.) functioning. Next, there are socio-economic indicators. The municipality of Saint-Amant-Roche-Savine lost jobs between 2010 and 2015. Saint-Amant-Roche-Savine is in a more critical situation in that it has a higher unemployment rate than the rest of the municipalities, or even compared to the regional and national averages (see Table 3).

Table 3. Statistical elements on demographic and economic fragility in the Ambertois territory. Source: INSEE data base, 2018.

\begin{tabular}{|c|c|c|c|c|c|}
\hline $\begin{array}{l}\text { Name of the } \\
\text { Municipality }\end{array}$ & $\begin{array}{c}\text { Average } \\
\text { Annual Rate of } \\
\text { Change in } \\
\text { Population } \\
\text { Growth in \% } \\
(2010-2015)\end{array}$ & $\begin{array}{l}\text { Population } \\
\text { Growth Due to } \\
\text { the Natural } \\
\text { Increase in \% } \\
\text { (2010-2015) }\end{array}$ & $\begin{array}{l}\text { Population } \\
\text { Growth Due to } \\
\text { Net Migration } \\
\text { in \% } \\
(2010-2015)\end{array}$ & $\begin{array}{l}\text { Change in Total } \\
\text { Employment: Average } \\
\text { Annual Rate between } \\
\text { in \% (2010-2015) }\end{array}$ & $\begin{array}{l}\text { Unemployment } \\
\text { Rate of 15-64 Year } \\
\text { Olds in \% (2015) }\end{array}$ \\
\hline Ambert & -0.5 & -0.5 & 0.0 & +0.2 & 10.9 \\
\hline Arlanc & -0.4 & -0.7 & +0.4 & +0.8 & 14.8 \\
\hline Cunlhat & -0.7 & -1.9 & +1.2 & +0.3 & 11.7 \\
\hline $\begin{array}{l}\text { Saint-Amant- } \\
\text { Roche-Savine }\end{array}$ & -1.3 & -0.9 & -0.3 & -6.9 & 21.9 \\
\hline $\begin{array}{l}\text { Auvergne-Rhône- } \\
\text { Alpes Region }\end{array}$ & +0.8 & +0.4 & +0.3 & +0.3 & 12.2 \\
\hline $\begin{array}{c}\text { France } \\
\text { (metropolitan) }\end{array}$ & +0.5 & +0.4 & +0.1 & 0.0 & 13.7 \\
\hline
\end{tabular}

\subsection{The Local Opinions on the Reception of Asylum Seekers in the Ambertois Territory}

In addition to the statistics on a fragile space, what is local public opinion on the reception of asylum seekers in the Ambertois territory? Of particular interest is the case of Arlanc, which registered $43.21 \%$ of the votes for Marine Le Pen, the candidate of the "Front National" (FN) party, in the second round of the 2017 presidential elections. It is a nationalist party that has historically placed the "immigration problem" or "national preference" at the heart of its electoral agendas. To collect local public opinion, I focused on the few local press articles that talk about this subject.

\footnotetext{
Translation: Disadvantaged areas.

Translation: Sensitive areas.

Translation: Ready to be broken.
} 
While immigration has been identified by some inhabitants as a possible explanation of the relative importance of the vote for the FN in 2017, others highlight that it may be due to loss of public services or to the media effect. ${ }^{6}$ Gilles Charreyron's (2015) analysis of the FN vote in Auvergne highlights the progressive anchoring of the party in the east of Auvergne, more industrialized, since the 2007 and 2012 presidential elections. "Les populations de ces territoires industriels de l'est auvergnat sont davantage aux prises avec une crise économique et une mondialisation qui créent de l'incertitude (désindustrialisation, délocalisations des entreprises, dumping social, perte de l'identité collective). La crainte de l'incident dans la vie professionnelle et sociale (chômage partiel, plans sociaux, reconversion professionnelle...) et la peur du déclassement font naître une inquiétude latente qui se retrouve probablement dans les urnes. Des électeurs fragilisés adhèrent plus facilement à la rhétorique du Front national sur le repli sur soi, la nécessaire protection des frontières face à la mondialisation et à la construction européenne, le "problème de l'immigration » et la "préférence nationale » en matière d'emploi et d'allocations." (Charreyron 2015, p. 11) ${ }^{7}$. This analysis, including the example of Arlanc, illustrates that the relative increase for the FN vote is not directly related to the settlement of asylum seekers, since it occurred only in 2016, four years after the 2012 election, taken into consideration in Gilles Charreyron's analysis (Charreyron 2015). It is mainly related to economic problems and the loss of public services.

\section{Discussion: Utilitarian and Humanitarian Approaches}

Two main approaches structure the reception of people seeking asylum: The humanistic approach and the utilitarian approach. These two approaches refer to a current of psychology for the first, and a concept of political philosophy for the second, which is not going to be detailed here. By humanistic approach, in the context of my research, I mean any action on the part of one or more actors who, in their commitment to the reception of persons seeking asylum, act for humanitarian reasons. As for the utilitarian approach, these actors place the positive economic and demographic contribution resulting from the reception of people seeking asylum for the areas at the heart of their strategy. When, for example, an actor refers to the "duty of reception" in relation to humanitarian emergency, we call this vision a humanistic approach. When in other interviews, actors highlight that "the reception of people seeking asylum is good for the economy and the demography of the areas," we call this vision, a utilitarian approach. There may be, in the discourse of some actors, a mix of these two approaches.

\subsection{Utilitarian Approach}

In non-metropolitan areas characterized by elements of demographic (loss of population) and/or economic fragility (unfilled jobs and loss of jobs), the utilitarian approach is present in the reception strategy according to the profile of the actors. During analysis, two important examples of the utilitarian approach of welcoming were visible in the Ambertois territory. First, there was the fight against housing vacancies in the social housing stock. With demographic difficulties and facing problems of attractiveness of the population, several social housing initiatives have remained vacant for several years. In Cunlhat, a building owned by a social landlord "Ophis du Puy-de-Dôme," has been vacant for more than five years (see Figure 5). The installation of the reception center has mobilized vacant housing to accommodate asylum seekers. For the social landlord, this makes it possible to rent vacant housing again and avoid financial losses. It also allows the social landlord to advertise to the local government that it is committed to a priority issue for the state, the reception of asylum seekers. This

6 https://www.lamontagne.fr/arlanc-63220/politique/pourquoi-arlanc-vote-t-elle-massivement-front-national_12394910/ \#refresh.

7 Translation: "The populations of these industrial territories in eastern Auvergne are more affected by an economic crisis and globalization that create uncertainty (deindustrialization, relocation of companies, social dumping, loss of collective identity). The fear of the incident in professional and social life (partial unemployment, social plans, professional retraining...) and the fear of downgrading give rise to a latent anxiety that is probably reflected in the vote. Weakened voters more easily adhere to the rhetoric of the National Front on self-doubt, the need to protect borders in the face of globalization and European integration, the "immigration problem" and the "national preference" for employment and benefits". 
commitment is used to assert itself with the state in future housing projects in which local government is an important actor. For mayors, mobilizing housing from the social landlord is seen as an opportunity to encourage them to develop other housing projects in their municipality.

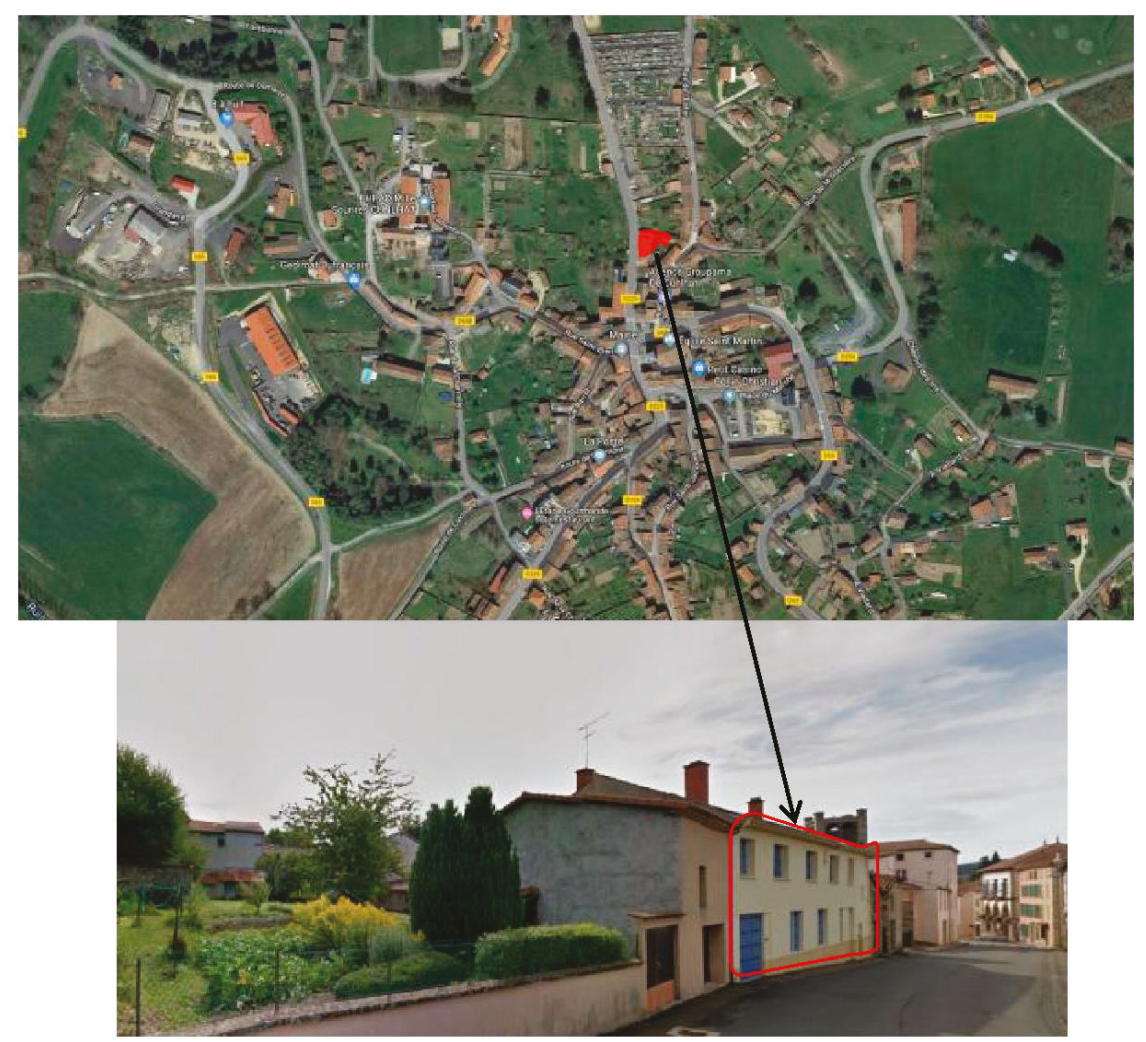

Figure 5. Vacant housing re-marketed to accommodate asylum seekers in Cunlhat. Base imagery (C) Google maps street view, 2019.

Furthermore, there is the example of school classes threatened with closure in areas with low population density. The elementary school in Saint-Amant-Roche-Savine had a problem in ensuring a required number of elementary school students to keep classes open. The mayor of the municipality requested, during the installation of the reception center, that his municipality welcome families with children. In addition to the availability of adequate housing for families with children in the municipality, this would make it possible to maintain the nursery school classes opened by the admission of asylum-seeking children. The approach of local actors, adopted in this context, was to focus on a duty to welcome asylum seekers.

In this context, the exiles' dispersal policy has made it possible to maintain public services and revitalize the housing market, severely affected by the demographic decline. For some interviewed volunteers, this observation is paradoxical, almost schizophrenic. On the one hand, the state decides to close public services because of the population decline; yet, on the other, the state decides to settle asylum seekers in these same territories with the risk that they will not have access to public services. 


\subsection{Humanitarian Approach}

Other actors, most of them volunteers, choose a reception strategy that only assists people they consider vulnerable. For some of these volunteers, their approach to welcoming is part of a political demand to claim the rights of people considered vulnerable.

The rejected asylum seekers, without the right to housing or work, depend on the help provided by humanitarian associations and volunteer networks. The installation of the reception center for asylum seekers was accompanied by a significant outpouring of solidarity from part of the local population. The volunteers were involved in several tasks, including learning French, food aid, socio-cultural support, organizing walks, and accompanying people to administrative or medical appointments. Noting the risks faced by the first people on their territory who were rejected, measures were put in place by volunteers. Thus, groups of volunteers such as that of "l'Élégante", in the Ambertois territory, host two families, totaling 10 people, whose asylum requests have been rejected. This accommodation is in a building rented for this purpose and now called "Résidence l'Élégante" (see Figure 6).

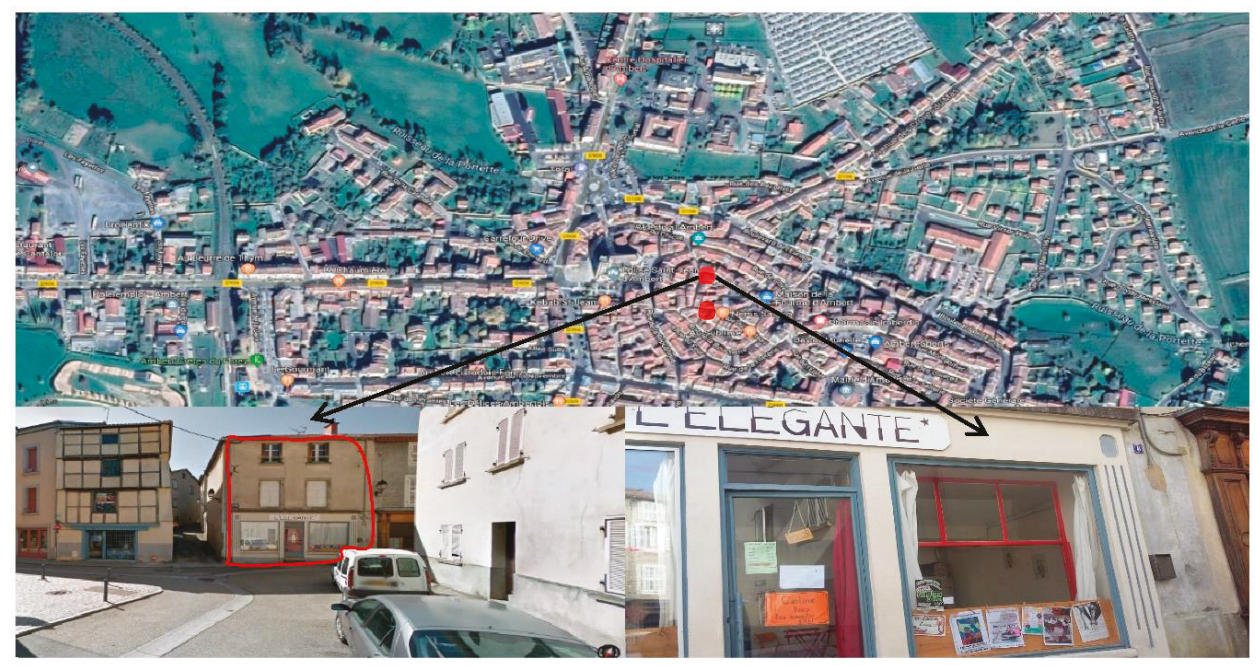

Figure 6. Residence "L’Élégante" in Ambert. Base imagery (C) Google maps street view, 2019.

In addition to accommodation, open-price canteens have been organized almost twice a week. In addition, there are musical events organized in the area with open-price admission. These activities have been organized in order to finance rental costs and survival of the families who have been refused accommodation. The "Résidence l'Elégante" also hosts spaces for political and cultural debates (feminism, installation of wind turbines, etc.). Some volunteers involved in the "Collectifl'Élégante" define themselves as anarchists. Some of them lived in large urban areas before settling in Ambert. Their actions are part of a struggle for social justice. The residents "L'Élégante" are not on the margins of this solidarity movement. They are involved through cooking, helping to organize cultural events, or even by proposing to participate in political debates. "I would like to organize a session to discuss the problems in my country. I have the impression that people here don't really know what's going on there." The approach adopted in this context calls for a right to reception.

The two humanistic and utilitarian approaches are interrelated and do not contradict one another. They reveal claims both for a duty to receive and a right to receive. This shift from the duty of some to the rights of others, has been reinforced with the exit of the first people to have their asylum claims rejected, in order to respond to the impasses of discretionary migration policies (absence of the right to exist at a place because of the absence of a residence permit issued by the State administration). For Agier (2018) in his book "L'étranger qui vient: repenser l'hospitalité", which is inspired by the writings of 
Emmanuel Kant (1795) in his essay "Projet de paix perpétuelle" on movement from the duty of one to the right of the other would consist in transposing the ideal of universal hospitality, in the name of which a growing number of citizens are mobilized, into a rule of law that every foreigner has the right not to be treated as an enemy, as Kant put it" (Agier 2018, p. 142).

How do these two humanitarian and utilitarian approaches to reception affect the integration of asylum seekers in the Ambertois territory? In the next section, I will analyze the asylum seekers' experiences in the Ambertois territory.

\section{Discussion: Asylum Seekers' Experiences}

The practice of space by asylum seekers is linked to their administrative status. Without the right to work, to train, and to live in a place of their choice, asylum seekers practice reception spaces as retention spaces. This is truer when it concerns a welcome in an area with limited public transport access and limited access to the services available in metropolitan area, like in Clermont-Ferrand. Asylum seekers also practice reception areas as spaces of solidarity. Faced with the confinement imposed by administrative measures restricting some of their rights, volunteers and collectives supporting exiles help them to overcome the political, economic, social, and mobility constraints they face.

The maps drawn in the cartography workshops highlight these spaces experienced by asylum seekers as spaces of both detention and solidarity. Thus, Besnik, from Albania, seeking asylum and hosted in Ambert, expercience his host territory between the sociability and the permanent stress of rejected his asylum application (see Figure 7). Qais, from Afghanistan, seeking asylum and hosted in Arlanc, expercience his host territory as waiting space, symbolized by "office" and "coffee," and the need of a better tomorrow symbolized "go to work" (see Figure 8).

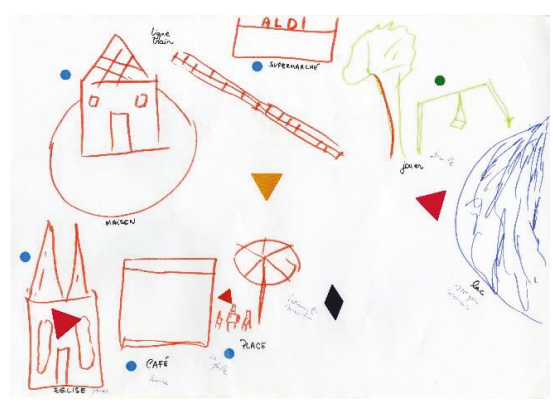

Figure 7. Map drawn by Besnik: Ambertois territory between stress and sociability. Source: Rafik Arfaoui, 2017.

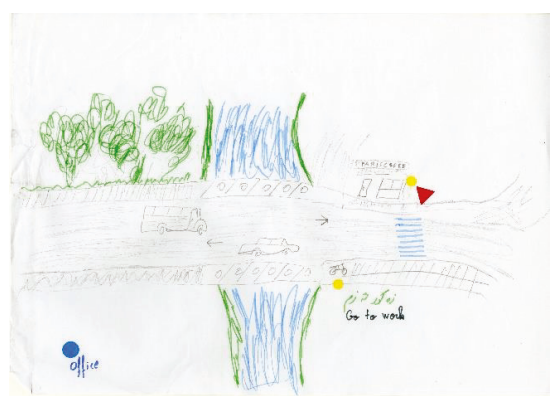

Figure 8. Map drawn by Qais: Ambertois territory between waiting and the desire to work. Source: Rafik Arfaoui, 2017. 
Between detention and solidarity, reception areas become, for asylum seekers, intermediate space-time that separates them between the experiences lived during their exile, and their uncertain futures. This intermediate space-time is similar to the airlock of a home or cinema. It is used to protect the interior space from the nuisances that could be caused by the exterior space. In this airlock, asylum seekers experience a situation of permanent stress from an uncertain future. They are perceived by the State as potentially "fake" refugees, a "burden" to be wary of and to be controlled.

The intervention of actors supporting asylum seekers in this airlock aims to integrate them into local society. This integration is temporary until a response is received from the administrations in charge of treating their request. Temporary integration is the action of local actors in support of exiles to accompany them towards autonomy. The aim is to facilitate the acquisition of resources that would enable them to overcome their dependence on the asylum administration. My observation of temporary integration in the Ambertois territory is in line with Emmanuelle Bonderandi's (2008) assessment that the dynamics of temporary integration is a characteristic of the migration process in which people seeking asylum are enrolling.

The "Stevenson model" on "well-treating organizations" (Bardonnet et al. 2016) seems interesting to identify and classify the actions of local actors that lead to the integration of asylum seekers. The model proposes two definitions (assumptions) of well-treatment and abuse:

- Any act/sign that contributes to a sense of increased autonomy (feeling that their ability) is well treated.

- Any act/sign that contributes to a weakened sense of autonomy (feeling that their ability to maintain their balance has weakened) is abuse.

This model contrasts with Maslow's pyramid in the sense that psychological and physical needs are considered equal. Applied to the question of integration, this model implies that the action of local actors is carried out without a hierarchy of importance between psychological and physical needs. In other words, reception is no longer limited to physiological needs but goes beyond them. Based on my field surveys, I have identified and classified the synergies of local actors for the integration of asylum seekers in the Ambertois territory according to the "Stevenson model" (see Figure 9).

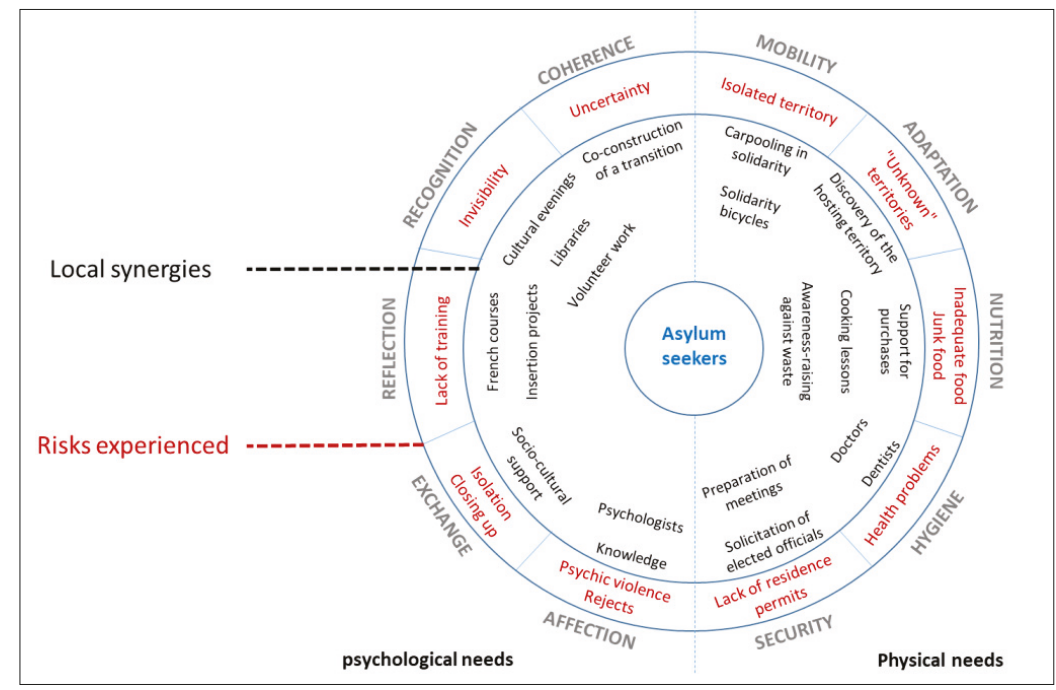

Figure 9. "Stevenson's model" applied to the integration of asylum seekers in the Ambertois territory. Source: Field research data base, Rafik Arfaoui, 2017 to 2018. 
Asylum policy in France does not sufficiently consider the integration of asylum seekers. Unlike Germany, for example, the asylum reform of 29 July 2015 does not include a budget for French language training for asylum seekers, considered as the main tool for integration. Thus, we can see that asylum seekers learn the French language through workshops organized by volunteers. These workshops are conceived as spaces of sociability between volunteers and asylum seekers. The dispersal policy complicates the integration of asylum seekers when they are received in fragile areas with little access to public services and public transport. The role of volunteers and support groups for exiles plays a fundamental role here too, by creating local synergies aimed at providing the tools for the autonomy of asylum seekers.

\section{Conclusions}

The integration of asylum seekers in the Ambertois territory is caught in a conflict between the local and national levels. It was born from the observation of local actors that there is a need for asylum seekers to face experienced risks. On the one hand, these risks are produced by asylum policies in France, which lead to a social, economic, and cultural fragility of people seeking asylum. On the other, these risks result from a geographical reality in the Ambertois territory with elements of demographic and socio-economic fragility.

Focusing my research on people seeking asylum makes possible the identification of the temporal dimension of integration. This is temporary and responds to time scales specific to the asylum application in France. This temporary integration is meant to be a step in the exile process that will enable people seeking asylum to acquire the social and cultural tools that will lead to their autonomy. This autonomy goes beyond the spatial limits of the Ambertois territory and concerns the scale of the French territory. It is the political and social expression of the rejection of the State policy of confinement of asylum seekers.

This study returns to the question of the effectiveness of the new system for resettlement of asylum seekers in France. This study does not provide a concrete answer as to the appropriate relocation system. However, it does provide some suggestions. These suggestions should be complemented by other studies in other regions of France.

First, human resources must be adapted to the geographical context of the settlement area. For example, diffuse accommodation structures located in several municipalities involve frequent movements of social workers. It is necessary that the budget allocated to accommodation facilities for asylum seekers takes this aspect into account. In this regard, several social workers have denounced the progressive loss of the dimension of socio-cultural support for asylum seekers to administrative support.

Moreover, it is necessary that the resettlement of asylum seekers be accompanied by the development of public transport and public services that can respond to the needs of both local residents and asylum seekers. It is also important that asylum seekers can have access to an employment contract, when it has been possible, and benefit from a budget for language learning. These two points are fundamental to their integration.

Finally, on a more global scale, it is important to respect the right of human beings to move freely. There is a worldwide injustice regarding the mobility of people. While citizens of rich countries have the opportunity to access a large part of the world without a visa requirement, citizens of poor countries have access to a tiny part of the world and, at the same time, struggle to obtain visas that allow them to move freely. From the global to the local level, we are today seeing a ghettoization of the world where undesirables are reduced to circulating in restricted spaces. Today, the question is about the right of people to mobility.

Funding: This research was funded by [Université Clermont Auvergne] through my Doctoral Contract.

Acknowledgments: I would like to thank all those who have enabled me to do this work, especially those who are seeking asylum, social workers, volunteers and all the local actors I met during my research field in the Ambertois territory. I would also like to thank the reviewers who helped me to improve my article.

Conflicts of Interest: The author declares no conflict of interest. 


\section{References}

Agier, Michel. 2008. Gérer les Indésirables: Des Camps de Réfugiés au Gouvernement Humanitaire. Paris: Flammarion, 349 .

Agier, Michel. 2018. L'étranger qui Vient: Repenser L'hospitalité. Paris: Seuil, 150p.

Bardonnet, Mickael, Michel Lefebvre, and Pierre Mongin. 2016. Les Organisations Bientraitantes. Paris: Adice Editions, 172p.

Bonderandi, Emmanuelle. 2008. L'accueil des demandeurs d'asile à la campagne: des étrangers d'un autre genre? In Les étrangers dans les campagnes. Edited by CERAMAC. Clermont-Ferrand: Presses Universitaires Blaise Pascal, pp. 329-46.

CAMIGRI. 2016. Les campagnes françaises dans la dynamique des migra:ons interna:onales. Available online: https://camigri.hypotheses.org/files/2017/10/CAMIGRI_INED.pdf (accessed on 7 May 2019).

Charreyron, Gilles. 2015. Le front national en Auvergne: À la recherche d'un enracinement? Approche territoriale du vote. Siècles 41. Available online: http://journals.openedition.org/siecles/2683 (accessed on 30 September 2016).

Edouard, Jean-Charles. 2017. Les petites villes du Massif central: ces villes que l'on dit plus fragiles? In Espaces Fragiles: Construction Scientifique, Dynamiques Territoriales et Action Publique. Edited by Roth Hélène. Clermont-Ferrand: Presses Universitaires Blaise Pascal, TERRITOIRES, pp. 141-61.

Mekdjian, Sarah, and Élise Olmedo. 2016. « Médier les récits de vie: Expérimentations de cartographie narrative et sensible », M@ppemonde, no 118. Available online: http://mappemonde.mgm.fr/118as2/ (accessed on 7 March 2018).

Mekdjian, Sarah, Anne-Laure Amilhat-Szary, Marie Moreau, Gladeema Nasruddin, Mabeye Deme, and Lauriane Houbey et Coralie Guillemin. 2014. Figurer les entre-deux migratoires. Pratiques cartographiques expérimentales entre chercheurs, artistes et voyageurs. Carnets de Géographes. Available online: http: //cdg.revues.org/790 (accessed on 1 July 2016).

Rieutort, L., ed. 2006. Un territoire sensible. In Massif Central, Hautes Terres D'initiatives. Clermont-Ferrand: Presses Universitaires Blaise Pascal, CERAMAC, Hors-Série, pp. 15-26.

Schneider Jan, Engler Marcus, and Angenendt Steffen. 2013. European Refugee Policy. Pathways to Fairer Burden-Sharing. Expert Council of German Foundations on Integration and Migration. Available online: http://www.svr-migration.de/content/wp-content/uploads/2013/12/European-Refugee-PolicySVRFB.pdf (accessed on 5 December 2016).

Young, Iris Marion. 1990. Justice and the Politics of Difference. Princeton: Princeton University Press.

(C) 2019 by the author. Licensee MDPI, Basel, Switzerland. This article is an open access article distributed under the terms and conditions of the Creative Commons Attribution (CC BY) license (http://creativecommons.org/licenses/by/4.0/). 
Article

\title{
The Linguistic Integration of Refugees in Italy
}

\author{
Rosella Bianco ${ }^{1, *}$ and Mónica Ortiz Cobo ${ }^{2}$ \\ 1 Institute for Migration Research, University of Granada, 18151 Granada, Spain \\ 2 Department of Sociology, Institute for Migration Research, University of Granada, 18151 Granada, Spain; \\ monicaoc@ugr.es \\ * Correspondence: rosellabianco@correo.ugr.es
}

Received: 27 July 2019; Accepted: 3 October 2019; Published: 10 October 2019

\begin{abstract}
The creation of laws regarding the linguistic integration of migrants has contributed to the change in Italian language teaching, which has had to adapt its materials and methodology to migrants. However, the specific case of refugees has not been specifically assessed, with the exception of experimentation with the Council of Europe toolkit for refugees. This paper aimed to study the linguistic integration of adult refugees in Italy by conducting an ethnography through participant observation and semi-structured interviews between Italian language teachers and refugees. The results of this work show both the teachers' perceptions of the refugees' linguistic integration and the refugees' perceptions of linguistic integration practice. The conclusions highlight the need for more hours of Italian language courses as well as lessons based on specific integration needs. Moreover, this study emphasizes that the integration practice itself implies language learning. A final consideration is made concerning the current integration situation of refugees in Italy.
\end{abstract}

Keywords: refugees; integration; Italy; Italian; education; language

\section{Introduction}

When defining integration, the European Commission states that this phenomenon "should be understood as a two-way process based on mutual rights and corresponding obligations of legally resident third country nationals and the host society" (Commission of the European Communities 2003, p. 17). Nevertheless, the practice of integration is often a unidirectional and assimilative process by which the migrant has to adapt to the host society by becoming part of it. One of the fundamental aspects of this process is linguistic integration into the host country. In reference to this, Europe has witnessed a shift along the years. In the 1990s, the Council of Europe recommended both the learning of the host country language and the promotion of the immigrants' language in order to maintain their identity. However, the current integration policies have put the focus mainly on the acquisition of the host country's language, which has become a tool with which to make decisions regarding immigrants' legal status (Pulinx et al. 2014; Council of Europe 1985). In this sense, language has acquired a role in migration control (Krumm 2012). Within the Italian territory, starting from the approval of the Italian Law Art. 4-Bis T.U. sull'immigrazione n. 286/98, the integration policies require a certified basic knowledge of the language for immigrants who want to apply for a long-term residence permit (Sergio 2011). Furthermore, according to the recent Italian decree DL n. 113/2018 (converted into Law n. 132/2018), Italian language certification is also required for citizenship applications. Compulsory knowledge of the Italian language draws attention to the assimilatory character of the integration process, which is not a prerogative of Italy as a country, but is rather a common aspect within integration policies all over Europe (Catarci 2014; Pulinx et al. 2014; Locchi 2012). Since the attention toward linguistic integration is mainly linked to the legal status of the immigrant, to date, less importance has been given to the linguistic learning needs of specific types of immigrant students such as refugees 
(Pinson and Arnot 2007). As a consequence, the language courses provided by EU member states are often not linked to the real needs of the students (immigrants or refugees), hence, there is an emerging necessity to provide courses that cover issues of practical interest such as labor insertion and other aspects of daily life (Fernández Vítores 2013; Extramiana and Van Avermaet 2011).

The purpose of this article was to contribute to the literature on refugee integration through language learning by investigating the integration practices of refugees and the real needs within the Italian context. On the one hand, researchers have analyzed the perception of teachers regarding the relationship between the integration of refugees and the Italian language courses. On the other hand, they studied the integration of the refugees and its relationship with language knowledge by analyzing the practice experience of the refugees. The analysis of the participant voices is essential to show the real needs and the actual integration practice lived by the refugees themselves, which seems to contrast with the integration policies of the host country. The main results of this paper show the need for language courses tailored to the integration needs of refugees as the existing courses are said to be insufficient for their integration, especially due to the inadequate number of hours provided. On the other hand, from the experience lived by the refugees interviewed, it was demonstrated that language competence is not only a means of assisting with integration, but also the result of the integration itself, since it is possible to improve the linguistic knowledge of the host country's language by socially integrating into the new community.

\section{Italian Language Learning by Refugees in Italy}

In recent decades, the growth in migration and the necessity to certify the language competence of migrants have increased the attention toward Italian language teaching in migration contexts (Locchi 2012; Sergio 2011). Consequently, new needs have appeared, such as rethinking the Italian didactics, providing alphabetization to adults, and adapting the Italian language certification to migrant users (Minuz et al. 2016; Minuz and Borri 2016; Borri et al. 2014; Balboni 2008; Rocca 2008). However, these changes have focused on the comprehensive category of 'immigrants', while the specificity of refugees has not been taken into account. In this regard, it is essential to specify that immigrants and refugees are two different kinds of migrants. The main difference lies in the reason that motivates the migration, which influences the migration dynamic. Immigrants decide to move mainly due to economic or familiar causes. For this reason, they are able to plan the migration and choose their final destination. On the contrary, refugees are usually forced to migrate, often due to impelling reasons (e.g., war, natural disaster, etc.). As a consequence, they have no possibility to plan their migration path and do not really choose a final destination. Furthermore, the legal situation regarding the migration status of refugees is different than that of immigrants. Often reaching Italy in illegal ways, refugees' first period in the host country is spent clarifying their legal situation in the country (which it can take up to several months and years). For this reason, they are usually dependent on the host agency, which is responsible of their first social and linguistic integration. In addition, the reasons that cause the migration of the refugees can have an effect on their learning. In this regard, it must be highlighted that refugees' learning abilities can be affected by the presence of mental health issues derived from life events particular to them (wars, persecutions, violence, etc.) (Delaney-Black et al. 2002; Saigh et al. 1997). Conditions of stress that potentially affect their life routine can also be derived from their particular living situation in the host country due to the restrictions that these imply (Campesi 2011; Kirmayer et al. 2011).

The particular needs of refugee students have only recently started to be addressed by Italian didactics. This is occurring especially due to the first phase of experimentation on the toolkit of the Council of Europe for the Education of Adult Refugees (Council of Europe 2014). This instrument aims to provide recommendations on the linguistic education of refugees through tools and resources designed to assist associations and volunteers who work with refugees. More specifically, it is organized into different sections and contains activities, guidelines and reference lists. The experimentation of 
this toolkit is taking place inside some selected provincial centers for adult education and training (CPIA), with the aim of specializing in refugees' linguistic education.

CPIA are one of the main entities providing Italian language courses to refugees in Italy. Other institutions include the Protection System for Asylum seekers and Refugees (SPRAR) and the Extraordinary Reception Centers (CAS). CPIA are public schools that offer alphabetization and Italian language courses for non-Italian nationals as well as the preparation of Italians and foreign nationals to obtain their diploma of the first cycle of the education. CPIA alphabetization and Italian language courses are taught to adult migrants and are structured to achieve, within a $200 \mathrm{~h}$ course, a basic language competence of Italian, that is to say, the A2 level of The Common European Framework of Reference for Languages (CEFR), which is the required level for a long-term residence permit (Ministero dell'istruzione, dell'università e della ricerca 2015). Such a level reflects an initial knowledge of the language, for which a speaker is able to use elementary vocabulary in order to communicate in daily situations (Council of Europe 2001). On the other hand, the courses provided by the SPRAR system to their hosted refugees count with a minimum of $10 \mathrm{~h}$ of Italian language taught weekly (SPRAR 2017).

To date, SPRAR have taught Italian language to asylum seekers, unaccompanied foreign minors, and international and humanitarian protection holders. However, it is relevant to say that the provision of Italian language lessons within SPRAR and CAS is undergoing a change. This is due to the recent Italian decree in matters of security, the DL n. 113/2018, or Decreto Salvini. According to this law, the new protection system would only offer its services to international protection holders and unaccompanied foreign minors, keeping out the asylum seekers and the humanitarian protection holders, categories that have benefited from this system until the Salvini decree. This is because, between the important changes of this law, the so-called Decreto sicurezza abolished humanitarian protection, a widely diffused kind of protection that up until now had granted a permit of stay to more than $20 \%$ of asylum seekers (data extracted from Rapporto sulla protezione internazionale in Italia 2017). As a result of these changes, humanitarian protection holders will be excluded from the hosting system, hence from any integration plan. On the other hand, asylum seekers will be hosted exclusively in CAS and First Reception Centers (CPA), rather than in addition by SPRAR (Algostino 2018). For this reason, they might no longer be entitled to receive integration support (e.g., work orientation services, legal and psychological support). In fact, according to the new law, CAS and CPA centers are not required to provide integration services (Galera et al. 2018). Consequently, such changes will affect the linguistic integration. Furthermore, there has not been much information as yet as to whether or not asylum seekers will be provided with Italian language courses. Furthermore, this new law guarantees linguistic education solely to international protection holders and unaccompanied minors, who are the only ones to whom the protection inside the "new SPRAR" system will be granted.

After all, the linguistic education provided to refugees in Italy is limited and generally designed to let refugees reach only a basic level of language knowledge (namely, the A2 level of the CEFR). Moreover, within the host agencies, the Italian language didactics are sometimes managed by volunteers without specific training. On the other hand, although professional language teaching is always provided in other contexts - the CPIA — such centers do not seem to be ready yet to provide specific teaching methods, although they are currently trying to adapt their methods to the teaching of refugees. The material used in these centers is usually designed for immigrants or foreign language learners, and not for the specific needs of the refugees. As a consequence, more appropriate material and methods are needed. Textbooks and lessons should be built on refugees' needs and daily life in order to provide immediate and useful help to their daily needs. For example, Italian language lessons should provide basic lexical knowledge, covering issues such as the asylum procedure, Italian documents, medical needs, job seeking, etc. In addition, special attention needs to be paid to alphabetization, since many refugees come from countries with very low education level and are not alphabetized either in their mother tongue. The current system does not really differentiate between the need for alphabetization and Italian language learning. That is, CPIA provides a $200 \mathrm{~h}$ course to achieve A2 level. Of the 200, 
$20 \mathrm{~h}$ are reserved to support activities for the students who do not possess enough competences to begin the A1/A2 course (Ministero dell'istruzione, dell'università e della ricerca 2015). In other words, only $20 \mathrm{~h}$ are dedicated to alphabetize the students. Such a period of time is obviously too short for an adult to learn how to write and read. Definitely, alphabetization requires independent and specific courses and surely an appropriate dedicated time length.

\section{Materials and Methods}

The methodology used for this study was ethnography, which was carried out by conducting participant observation and interviews. This type of methodology facilitated the approach to the context and subjects of the research in a natural way because according to ethnographic methodology, the researcher has a participatory role in the daily life of people. In fact, for an extended period of time, the researcher carefully observes the subjects of the research, collecting any available and valuable data for the research (Hammersley and Atkinson 2007). For this reason, a long period of field work allows for integration in the context of study, hence, it facilitates a deep knowledge and interpretation of the reality (Álvarez Álvarez 2008; Goetz and LeCompte 1998).

\subsection{The Context}

The research was conducted in Salento (Italy) in the Puglia region. More specifically, it was carried out within the province of Lecce, which comprises 97 municipalities. The majority of these municipalities are not highly populated, if we consider that 62 out of the 97 have a population between 2000 and 9999 people. Only Lecce, the capital, has more than 60,000 inhabitants. Moreover, due its socio-economic situation, a general depopulation of the area is taking place (Epifani and Forte 2018) because this area is located in the south of Italy, which is a less economically developed part of Italy and the most affected by unemployment. Specifically, if we compare the unemployment trend for the whole country with that of Puglia and Salento, a great proportion of unemployment can be observed in these last two areas. In fact, while Italy counted a loss of 332,000 employed workers during the period 2008-2016, the Puglia region counted 84,000 less employees and the area of Salento, 18,000 (Forges Davanzati and Giangrande 2018).

From another point of view, regarding the refugee hosting system, according to the last available data, this region is among the first five Italian regions for the number of active SPRAR projects. That is, compared to other Italian regions, Puglia is an area with a larger refugee presence. Specifically, this region is the third highest Italian region for the number of refugees that have been hosted in the SPRAR system (SPRAR 2018). In total, according to the data of 2017, the refugees hosted in Puglia numbered 14,452. Of these, 8042 were hosted in the CAS system, 3461 were hosted at First Reception Centers, and 2949 were hosted inside the 123 SPRAR centers for the region (Anci et al. 2017).

Regarding our research, the study context was Italian language classes organized by centers attended by adult refugee students in the Lecce Province (in order to protect the privacy of the informants, the name and the specific location of the centers are not be specified in this article).

Conducting the research in this context is of considerable interest. The first regards the language education context because language represents not only the expression of thoughts but also a cultural practice implying belonging to a group and its rules (Duranti 1997). For this reason, analyzing the informants' relations with the languages and the learning of the host country language is a way to study their relationship to social groups, hence their identity formation. Secondly, regarding the geographic context, we considered of great significance the analysis of the refugees' linguistic integration and language attitudes in an area with a high unemployment rate and a tendency toward depopulation.

\subsection{The Observation}

A participant observation period of seven months was carried out in five Italian language classes at three different centers attended by adult refugee students. The observation period facilitated the approach to the context and the informants of this research, who were the refugee students, and their 
Italian language teachers. However, particularly in the case of the refugees-informants can be more reluctant to open up to researchers-a deeper approach was needed, and we chose to also enter into contact with them in more informal situations outside of the Italian language class context. That is to say, the first author, who carried out the collection of the data, participated in Italian language courses in the role of teaching assistant and mediator to observe the subject of study within the formal context of language teaching. By covering the role of the teacher and mediator, the researcher was able to observe the subject of study from the inside and directly participate in the class activities.

The second step of the data collection was carried out through the use of the social media website Facebook, through which we chain contacted the contacts related to one of the informants attending the Italian language class. In this sense, Facebook allowed us to reach additional students and make contact with them within an informal situation. Creating a friendlier relationship and meetings within contexts that did not concern the school or the host agency helped us to earn the trust of the refugees in order to have stress-free conversations. In this regard, it must be highlighted that "interviewing, like observing, is a skill, and requires the interviewer to pay attention to a range of factors, from the interview venue to the interaction between the interviewer and the interviewee" (Copland and Creese 2015, p. 37). In fact, it is necessary to point out that due to the condition of being asylum seekers, the main relationships that they establish in Italy are with lawyers, police officers, and mediators. As a consequence, this situation can drive them to feel stressed and anxious when being 'asked questions', hence their answers could be affected by what is thought to be 'better to say'. While on the one hand, a deeper approach has helped in earning their trust to obtain more sincere answers, on the other hand, it has raised the ethical issue of "exit from the research site after being befriended by refugees" (Jacobsen and Landau 2003, p. 192).

Furthermore, it must be highlighted that a research approach that implies strict contact of the researcher with the participants inevitably raises the issue of the reflexivity of the researcher on the subjects and data. However, as Hammersley and Atkinson (2007, p. 16) pointed out, "the fact that as researchers we are likely to have an effect on the people we study does not mean that the validity of our findings is restricted to the data elicitation situations on which we relied. We can minimize reactivity and/or monitor it. But we can also exploit it: how people respond to the presence of the researcher may be as informative as how they reach to other situations".

\subsection{The Interviews}

Collecting data from both the refugees and the teachers allowed us to obtain not only a deep understanding of the teaching practice within the studied context, but also a better knowledge of the real needs of the refugee students regarding Italian language learning.

A total of 51 semi-structured in-depth interviews were conducted for this study, 28 of which were conducted between the refugee students and 23 with Italian language teachers.

The main concepts that were addressed during the interviews with the refugees were their motivation and expectations for learning Italian, the student's relationship with Italian learning, the use of their spoken languages, the migratory experience and integration process, and, finally, their relationship with the Italian country and its society.

In contrast, the interviews conducted with the teachers mainly discussed their teaching practice experience and their perception of the benefits that such courses can have on the practical life of the refugees. Furthermore, prior to deep discussion on these subjects, the teachers were asked for their opinions about the refugees' specific learning needs or difficulties, and the training of teachers who work with them.

\subsection{Data Analysis}

In order to proceed with the analysis, each group of interviews was transcribed in a Microsoft Word file and coded according to the interview data (Copland and Creese 2015). Regarding the interviews carried out with the teachers, we extracted the discourse inherent in the teachers' opinion 
about the outcome of the course according to the integration needs of the refugees. In particular, we analyzed the content regarding the opinion of the teachers about

- $\quad$ The influence of the course design (e.g., used material and dedicated time),

- The influence of the type of student,

- The external influence (due to regulations and organization of Italian language courses for refugees).

On the other hand, regarding the interviews carried out with the students, we considered the discourse on the relation between language and integration. In detail, the interviews' content was categorized according to the following subjects:

- Relation of the Italian language with work,

- $\quad$ Relation of the Italian language with daily needs,

- $\quad$ Relation of the other languages with integration and relocation in EU.

Following such categories, the extracts of the interviews related to each code were regrouped and analyzed according to a qualitative approach.

\subsection{The Participants}

Regarding the selection of the informants, random and non-random techniques were used. Interviews were conducted randomly with the teachers and some students of the language lessons observed. In order to reach more informants, the snowball technique was also used, which allowed us to make contact with other informants (Valles 2003).

There were a total of 51 informants in this study. 28 were adult refugee students who were asylum seekers or protection holders. The other 23 were Italian language teachers for migrants working inside the CPIA, CAS and/or SPRAR.

The origin of the refugees and their spoken language(s) varied. Their countries of origin (and nationalities) were as follows: Nigeria (5), Pakistan (5), Gambia (4), Senegal (3), Bangladesh (3), Syrian (2), Ivory Coast (1), Guinea (1), Egypt (1), Niger (1), Mali (1), and Ghana (1).

\subsection{The Researcher and Informant Role in This Study}

Due to the various origins of the refugees, in order to conduct our research, it was necessary to use more than one language. To achieve this purpose, the linguistic knowledge of the first author (the researcher conducting the interviews) was both an advantage and a disadvantage.

The first author is plurilingual and able to speak Italian, French, English, Spanish, Portuguese, and some Arabic. Thanks to the knowledge of common linguas francas of the refugees (English, French, Portuguese, and Arabic), it was possible to reach more students than it would have been if the interviews were only conducted in one language. However, although in some rare cases, the Arabic and Portuguese languages were additional helpful languages in clarifying what was not understood by speaking the other linguas francas, the main languages used by the researcher to communicate with the refugees were English, Italian, and French.

However, due to the various origins of the refugees, the knowledge of these languages was not sufficient to allow fluent communication with all of the participants, especially in the case of some of the refugees who did not speak a lingua franca. In these cases, as we did not have an interpreter for their languages, these refugees were automatically excluded from the selection; however, this was the case for only very few students. For example, some Bangladeshi students were only able to speak their mother tongue; however, in the case of the other three Bangladeshi refugees, the interviews were made possible by the presence of a Pakistani student that was able to act as an interpreter when communicating with them.

Another remark on the influence of the researcher in the study needs to be made regarding the researcher's knowledge of the area. The first author knows the geographic area of the research well, 
because it is the same place where she lives. Similarly, due to her previous education and working experience in the field, she has good knowledge of the refugee hosting system and the provision of language courses in the area. Undoubtedly, this facilitated the development of this research as well as providing a better comprehension about the living conditions of refugees.

\section{Results}

\subsection{Perceptions of the Teachers Regarding the Effectiveness of the Italian Language Courses on Refugee Integration}

The language courses organized by the CPIAs, SPRARs, and CASs aim to prepare students to attain the A2 level of the CEFR, that is, a basic knowledge of the language. However, according to the teachers interviewed in this study, in many cases, these courses are not enough to reach this level.

According to the words of Barbara (the names are pseudonyms to ensure anonymity), this was also the case at her school. Despite her school offering $80 \mathrm{~h}$ more than the 200 usually offered by this type of institution, the students failed at reaching the required level. She said: "In the CPIA, the course is 200 standard hours, $280 \mathrm{~h}$ for those who are illiterate. The final goal is the level A2, as it is required by the prefecture. I would also say that few students manage to reach the A2 level in just one school year, I mean, following the provided $200 \mathrm{~h} . "$ As she said, many students need to repeat the course, thus follow a $560 \mathrm{~h}$ course in order to reach that level. This is an admitted practice by the CPIAs, which allow students to repeat the course one more time.

Generally, the need to repeat the course is due to being illiterate or having had a previous very low level of education. Such situations are commonly found in the students of all of these kinds of courses. For example, Michela, a teacher at a SPRAR, told us of her experience with an even shorter course and said that "The available hours are not sufficient to satisfy the linguistic needs, especially for illiterate students, whose path is more delicate. [ ... ] On average, for each refugee, $40 \mathrm{~h}$ are provided, and, after an entry test, only the lowest level ones enter the courses, up to A2. [ ... ] Very often, the course ends exactly when the illiterate student has begun to become familiar with the letters of the alphabet and the sounds".

From the experience of the interviewed teachers, it seems that the total number of hours is not sufficient to face the difficulties in educating an illiterate adult student. In fact, the school's efforts are very often not enough, even though both CPIA and SPRAR centers offer parallel courses to the students in order to potentiate their learning. Hence, refugees very often follow both courses at the same time. These dynamics were explained by Giovanna, a teacher at a SPRAR: "I follow the French mother tongue students, I mean those who use French as a vehicular language. In total, about $150 \mathrm{~h}$ per year. Let's say that the goal is to educate the illiterates and support the path followed at the CPIA for all those who already attend the official CPIA courses. This support and remedial activity works very well, as an after-school."

Nevertheless, despite it being very common to follow two courses in parallel, such preparation is not enough to meet the needs of daily life, as explained by Marta, a teacher at a CPIA: "Unfortunately, for most of the students, the $200 \mathrm{~h}$ are not enough to reach a level that allows them to look for work and to be able to really fit into the social fabric."

A similar comment was made by Giulio, another CPIA teacher, who lamented the generally low level of education of the refugees at the end of the $200 \mathrm{~h}$ when entering the course to obtain a diploma for the first cycle of education. He said: "The situation is not easy at all, how can they study mathematics if they can barely speak Italian? Many of them still have big issues with writing and reading. This makes them so slow."

As CPIAs also offer adults the possibility of obtaining a certificate of the first cycle of education, some refugees enter this course after completing the $200 \mathrm{~h}$ Italian language course path as successful completion of the $200 \mathrm{~h}$ course is a prerequisite for entry into the first cycle of education, as the student needs an A2 level of Italian in order to access that course. 
According to the data collected by this study, teachers believe that the hours provided by the Italian language courses are insufficient to allow the refugee to enter the education system or integrate into society by entering the work field. Longer courses are required as well as a different teaching approach that is more focused on the integration of the refugee into society, hence using a more practical approach rather than "grammatically-oriented" classes. Regarding this subject, Carla, a CAS teacher, commented: "The ideal would be to reduce the hours of the formal lessons, alternating them with more practical meetings-also on the basis of the cognitive styles of the learners-perhaps by providing ad hoc courses set up on contextualized scenarios of the host community."

Nevertheless, another common concern of the teachers at SPRAR and CAS centers is related to the changes introduced by decree $n$. 113/2018, hence the diffused fear of cutting the Italian language courses for some types of refugees (Galera et al. 2018). This was expressed by Anna, a CAS teacher: "With the Decreto Sicurezza everything is unsure now, for them and for us. Unfortunately, we fear that there might not be any more courses for the asylum seekers. It is like all students I have now, after some months, will not follow the course anymore. I will have much, much, less students, and I might also not have a job." The fear expressed by Anna is a common preoccupation of the teachers that work for agencies that host refugees in that there is uncertainty about the provision of language courses for asylum seekers, which could also imply that the teachers themselves could lose their jobs.

\subsection{Refugee Language Competence and Work}

Asylum seekers face multiple integration challenges simultaneously. They adapt to the language and customs of the new society, face difficulties in the bureaucratic procedures to be granted protection, and work within a new societal environment. Such challenges interfere with each other, which is the case of integration and language knowledge. When language competency is high enough, this can positively influence integration. In contrast, integration can be hindered when the competence is too low. For this reason, within the integration policies of almost all European countries, language is a compulsory requirement (Pulinx et al. 2014). On the other hand, language competency seems to be potentially affected by the integration process, as shown in this section.

For refugees who work, formal language learning is difficult to access, because they have no possibility of going to school. That is, once refugees find a job, they might withdraw from the language course. In various cases, the refugees in this study demonstrated that at a certain point, they had to quit formal language learning in order to go to work. Ahmed, a Pakistani refugee who reached Italy at the end of 2017, followed the language course offered by the CAS where he was hosted, until the moment he found a job. He explained: "I did not go to lessons from last two months [ ... ] Because from one month and half I am working, but not regular. Class is three days in a week, Monday to Wednesday, sometimes school also off. [ . . . ] I hope if I will do work with Italian people more and more I will learn much better than school because according to me the major thing is that if someone has no hesitation, he or she can speak, even learn, much better."

In these cases, formal language learning is affected by the practice of work. That is to say, the student does not receive formal learning because they are busy at work. Furthermore, it must be highlighted that this does not necessarily coincide with the interruption of language learning. On the contrary, language learning is a result of working. Hence, rather than representing only the first requirement to integrate within the new society and get a job, language is linked to work in a mutual process: language sustains the work activity and vice versa.

Although language knowledge is specifically required by laws that regulate the integration of migrants (art. 4-Bis T.U. sull'immigrazione n. 286/98; DL n. 113/2018), the practice of work integration shows that language competence is not always needed. In fact, as Ahmed says, language is learnt in the workplace. Despite having little familiarity with the language, step by step, the difficulties are overcome by the work practice. In this sense, the workplace becomes the place where the language is learnt and practiced. This is also what William, a young Nigerian man, told us when we asked him if he faced language problems at work: "Yeah, I had little bit problems. Mostly I understand what they 
are saying. Because I have no problem, as I want, I speak Italian, it does not matter I am speaking good or not, but most important for me I can convey my messages to them easily. At beginning it was little bit harder but time by time I recovered all. Now, sometimes I feel little bit problem but I can understand what they are saying to me and what they want from me. So in any case I am working according to their choice [ ... ] Actually, it is our daily routine working, I can guess what they are saying in case I could not listen well or understand them. But now I am working properly, I have no problem for any matter. [ . . . ] It is mainly a handwork."

The need for a higher or lower level of language depends on the kind of work that is undertaken. In the case of William, who worked as a dishwasher-a very common job held by the refugees interviewed-this type of work does not really require specific linguistic knowledge as it is repetitive work, so he can usually understand what he is being asked to do.

Nevertheless, in the case of work that requires contact with people, the language knowledge is a plus and can represent a way to improve their working conditions. This is the case of Sajjad, a Pakistani refugee who also worked as a dishwasher. Sajjad, when telling us about his experience in the job search, affirmed: "Today I have asked from four places and I have found two jobs. [ ... ] I found a job as a waiter. I said: 'I am so sorry I cannot because I cannot speak properly'. [ . . . ] I think this year I work as a dishwasher. Next year I will speak Italian so well, I can work as a waiter". In cases like this, linguistic knowledge of the host country's language is a means by which to find work or to get a better position.

From another point of view, it must be highlighted that being a refugee often means being alone in the host country and not being able to count on the mediation help of other people such as family members or friends when facing their first integration challenges. For this reason, language can represent an obstacle when dealing with work-related needs. This is the case, for example, when needing to understand a work contract, which is not an easy task due to the kind of language used in it. As Mamadou, a young Nigerian refugee, told us, this can be incredibly frustrating and even lead to misunderstandings: "Yesterday I asked everybody for help, I went here and there. All the day looking for someone who can help understand the contract. You know, I tried to translate it but it is written in very hard words. I searched a lot but I did not find anybody to help me. At the end I signed the contract and gave it to my employer. Today, I showed the contract to the lawyer and he told me 'why did you sign it?' I do not know why they wrote six hours, we agreed on eight hours".

\subsection{Language Competence for Other Needs Integration-Oriented}

Although the work context constitutes the main place where refugees practice their host country's language, other social situations (such as going to the doctor, handling issues regarding the asylum procedure, going to supermarket, etc.) also require its knowledge. In this regard, linguistic impediments similar to the example of the work contract are faced by refugees, that is, it can be difficult in other situations because of the bureaucratic issues related to their asylum application. A common problem between the refugees interviewed was the difficulty in having a deep comprehension of the administrative procedures. For example, when we asked Mohammad, a Bangladeshi refugee, how he felt about his upcoming commission interview, he related: "They did not prepare me. It is not good really. I cannot speak Italian, also, well. There is huge discrimination here. Anyway one day I will go to the office and tell them you do not treat equally." It is clear that the linguistic obstacle in this case was an additional difficulty that contributed to the stress felt by the asylum seeker.

Hence, in direct and indirect ways, language is needed for integration within the new community, and is a means through which work can be obtained. This is also the case when getting a driving license. In this regard, Hamad, a Pakistani refugee, said: "The problem here is that if you do not have a car you are disabled. I need a motorcycle to go to work. In winter, you cannot walk or cycle in the rain. Next year, I will go for my driving license. I need to speak Italian well to do it."

For certain, knowing the language of the host country can represent a way to overcome the obstacles that lead to integration. Moreover, situations like that of commission interviews or driving license courses are between the first linguistic contacts that refugees have with locals out of the language 
course context. In these cases, language is improved, refined, and practiced in real situations. Hence, social contacts constitute a way to learn the language in an informal way, and for this reason, are as equally important as formal language learning.

However, contact with local people did not seem to be frequent, and was mainly limited to work and a few other situations. For this reason, the workplace seems to be the main informal language learning context.

Regarding contact with the locals, it was very common for the refugees in this study to make assertions like the one by Mahmoud, a Senegalese man, who affirmed: "I don't know anybody here. I don't speak with anybody. In the house, I talk sometimes with the guys, but few. Everybody has his problems. I only speak with my family at phone."

Integration seems, in this sense, to be very limited and hard to reach, since refugees seem basically relegated to their circumscribed community. Although other informants described the locals as welcoming people and referred to daily greetings with them, the linguistic exchange did not seem to extend beyond greetings. As John, a Nigerian man, said: "I think people here are good ... Here everybody knows me, if you go to supermarket and you tell them my name, they know me. They can tell you where I live. It is a small town. [ . . ] I have no friends here, I talk only with others in the camp, but I don't talk about my life."

Therefore, although the size of the town allows people to get to know and recognize each other easily, the establishment of relationships with the locals is not guaranteed, hence, once again, language practice is hard to realize.

Another factor that influences language practice and integration into the social fabric is surely the difficulty of finding work. This is a difficult task in Italy nowadays, even more so in the Salento area, since the unemployment rate is rising and the small towns are consequently depopulating (Epifani and Forte 2018; Forges Davanzati and Giangrande 2018). Refugees can hardly find work in villages and small towns, as John told us: "I searched for jobs around here but there are no jobs. Restaurants tell you to come back in summer. In winter there is no work".

As John says, work availability depends on the season, because during the touristic period, there are more chances to find jobs. This reason contributes to the isolation of the refugees, which hinders integration, both social and linguistic, into the host country. As already mentioned, work is one of the main places where refugees can practice their language skills as well as a way through which they can integrate into the host country. Consequently, for refugees who work but do not have other social contacts, informal language learning within the workplace can play an important role in the development of linguistic knowledge. This is because, as already mentioned, other social contacts that foster language learning are very limited.

\subsection{Other Language Competency and Practice}

Immigrants and refugees are asked to integrate into the new society by learning its language, thus following an assimilatory approach. Such an approach considers linguistic integration in a unidirectional and monolingual way. That is to say, the relationship of the individual with other languages such as their linguistic repertoire or the need to learn other languages is neglected and not valued (Bianco and Cobo 2019). However, refugees usually own a rich multilingual repertoire, also due to their migration path (Bianco and Cobo 2018).

The practice reality shown by this research demonstrates that the Italian language is not the only language spoken in Italy by refugees. In social contexts such as the workplace, other languages are also spoken. Benjamin, a refugee from Nigeria, told us that in his workplace, there were other refugees with different nationalities. This is how he explains his method of communicating with his co-workers: "I speak Italian when we don't understand each other. There are people from other countries. I usually speak English with them. Until a month ago there was someone from Nigeria, I used to talk my language with him, because he speaks my same language." 
Evidence like this is common between the participants of this study and shows that refugees usually have a rich linguistic repertoire and can choose which language to speak according to the context and the person they are sharing a conversation with. They use Italian, but also lingua francas or their mother tongue.

From another perspective, it can be seen that the migration path of some refugees does not conclude in Italy. On the contrary, some refugees aim to continue their migration. For this reason, they are interested in learning other languages. For example, we quote the words of Alaa, a Syrian refugee: "My goal was to go to Sweden, but they didn't let me stay (there) because I entered Italy first. Actually I have many friends who moved to Sweden. So, my plan is to reach them as soon as I can. Life is good there. I will live there and make my family there. [ . . . I I will start again all, I will learn their language, make papers, etc."

As demonstrated by Alaa, learning the host country's language was sometimes not included in the goals of the refugees, as their real migration path had not finished and they did not really plan to integrate and live permanently in Italy.

A final language remark has to be made regarding dialect learning. When not attending the Italian language course as they often have to withdraw due to work reasons, refugees learn the local spoken language between people. This is mainly the case for those who spend their time begging for money or sell items on the street. The absence of a formal linguistic education and the frequent relationship with low educated Italians (e.g., within the market sellers sector) allows them to learn and exclusively speak the local Italian dialect. However, these refugees do not distinguish between the language they speak and the formal Italian language. This has raised the attention of the need for a formal education for refugees who want to continue their life in Italy because if they should choose to move to another Italian region, they might face linguistic differences that might impede their comprehension.

\section{Conclusions}

The results of this study show two perspectives on the linguistic integration of refugees in Italy. The first was provided by Italian language teachers, while the other was given by the refugees themselves. According to the results of this study, teachers thought that the courses provided were not enough to allow the refugee to be able to integrate. On the other hand, the practice of refugee integration demonstrated the opposite. An example of this is given by the fact that refugees managed to integrate in the workplace even with very little knowledge of the national language.

As stated by the teachers, the Italian courses provided were not enough to reach the A2 required level, even when the course was repeated and taken in parallel with other Italian courses. This means following a $200 \mathrm{~h}$ CPIA course twice as well as a SPRAR/CAS course in parallel, which generally consists of at least 10 hours per week (SPRAR 2017; Ministero dell'istruzione, dell'università e della ricerca 2015). The causes of the inefficiency of the courses were mainly illiteracy and a low education level among the students, difficulties that are difficult to overcome with the course hours provided. Therefore, teachers think that the level reached by the refugees at the end of the course is not enough for them to integrate within the social fabric, including looking for work or entering into the first cycle of education.

According to teachers, there is a need for longer courses as well as a teaching approach based on the real integration needs of the refugees such as practical learning methods (that is, methods more based on daily conversation needs rather than on grammatical aspects). This calls for attention to the need for more informal teaching practices, which could be given inside the workplace by organizing language courses within the work context that are tailored to the area of work.

Nevertheless, despite the level reached by the students, various refugees did manage to find work. Hence, it was shown that their workplace also promoted improvement in their language skills. In this regard, we remark on how informal language learning has the same importance as formal learning. However, the social contacts made by refugees seemed to be limited due to their isolation, the lack of opportunities to build social networks with the locals, and the diffused unemployment in the towns in 
this study. In contrast, for working refugees, work represented the main learning context. Moreover, language and work seemed to be linked in a mutual process: language supports the work activity and vice versa.

Furthermore, although Italian language is specifically required by laws regulating the integration of migrants, it can be that in not all cases is language a compulsory requirement of work, as some kinds of jobs do not require much communication. Still, in other cases, language is a requirement to find work or obtain a better job.

Moreover, it must be highlighted that specific language competencies are needed in situations linked with integration and work. Some of these, like understanding a work contract or having a better comprehension of their own asylum procedure are specifics related to refugees. It must be said that as they are often alone in the host country, they cannot count on the assistance of friends or family members. For this reason, specific linguistic assistance and education is needed in order to provide refugees with at least an initial means to face similar situations.

From another point of view, we highlight the relationship of the refugees with other languages, both their spoken languages and those they would like to learn. Multilingual needs are typical of refugees due to their migration path and their migration plans. This is the case of the individual whose goal is to relocate to another country and that of refugees who use lingua francas or their mother tongue to communicate with other non-Italians in Italy. In this regard, there has been no attention paid to the various linguistic repertoires possessed by the refugees. However, learning the host country's language is the exclusive central point of the integration needs required by the national policies.

Concluding, we can remark that, according to the real needs of the refugees, other languages should also be taken into account, especially regarding the learning of languages for refugees who intend to relocate.

On the other hand, the ideal language education for refugees should comprise linguistic integration courses providing specific knowledge about issues like the asylum procedure and the Italian work system as well as other useful subjects like how to obtain a driving license. In addition, courses should provide more teaching hours. Furthermore, lessons for higher levels should also be provided, in order to fully accompany the refugees in their integration. Such courses should take into consideration that adult students have difficulties studying and working at the same time. In addition, working refugees need specific linguistic training related to their work. Hence, the organization of language courses within the work context should be considered.

These ideal practices seem to clash with the preoccupations expressed by the teachers regarding the future provision of Italian language courses for refugees, as law n. 132/2018 does not guarantee any more integration assistance to asylum seekers and humanitarian protection holders, which means that they could also be kept out of linguistic education (Galera et al. 2018). For this reason, it would be interesting, in the near future, to explore how the recent policy changes will influence the provision of language courses and linguistic integration, particularly to asylum seekers and humanitarian protection holders.

Author Contributions: R.B. and M.O.C. contributed to conceptualization, methodology, supervision, formal analysis, and reviewing and editing. R.B. contributed to data curation and writing the original draft.

Funding: This research received no external funding.

Conflicts of Interest: The authors declare no conflict of interest.

\section{References}

Algostino, Alessandra. 2018. Il decreto "sicurezza e immigrazione" (decreto legge n.113 del 2018): estinzione del diritto di asilo, repressione del dissenso e diseguaglianza. Costituzionalismo.it 2: 167-99. Available online: http://www.webcitation.org/query?url=http $\% 3 \mathrm{~A} \% 2 \mathrm{~F} \% 2 \mathrm{Fwww} . \cos$ tituzionalismo.it $\% 2 \mathrm{Farticoli} \%$ 2F685\%2F\&date $=2019-04-12$ (accessed on 12 April 2019). 
Álvarez Álvarez, Carmen. 2008. La etnografía como modelo de investigación en educación. Gazeta de Antropología 24: 1-15. Available online: http://www.webcitation.org/query?url=http\%3A\%2F\%2Fwww. gazeta-antropologia.es\%2F\%3Fp\%3D2347\&date=2019-04-17 (accessed on 17 April 2019).

Anci, Caritas Italiana, Fondazione Migrantes Cittalia, SPRAR, and UNHCR. 2017. Rapporto Sulla Protezione Internazionale in Italia 2017. Roma: Gemmagraf, Available online: http: //www.webcitation.org/query?url=https\%3A\%2F\%2Fwww.unhcr.it $\% 2$ Fwp-content $\% 2$ Fuploads $\%$ 2F2017\%2F10\%2FRapporto_2017_web.pdf\&date=2019-04-12 (accessed on 12 April 2019).

Balboni, Paolo E. 2008. Italiano L2: una via italiana. Studi di glottodidattica 1: 17-31. [CrossRef]

Bianco, Rosella, and Mónica Ortiz Cobo. 2018. The migration experience and the informal language learning of refugees. In Conference Proceedings. Innovation in Language Learning 2018. Bologna: Filodiritto.

Bianco, Rosella, and Mónica Ortiz Cobo. 2019. La integración lingüística de los refugiados en Italia: políticas lingüísticas en la clase de segunda lengua. In Modelando el transnacionalismo. Edited by Jeffrey H. Cohen and Paulette K. Schuster. London: Transnational Press, pp. 151-70.

Borri, Alessandro, Fernanda Minuz, Lorenzo Rocca, and Sola Chiara. 2014. Italiano L2 in Contesti Migratori. Torino: Loesher.

Campesi, Giuseppe. 2011. La detenzione amministrativa degli stranieri: Storia, diritto, politica. Democrazia e diritto 48: 177-225. [CrossRef]

Catarci, Marco. 2014. Considerazioni critiche sulla nozione di integrazione di migranti e rifugiati. REMHU 43: 71-84. [CrossRef]

Commission of the European Communities. 2003. Communication from the Commission to the Council, the European Parliament, the European Economic and Social Committee and the Committee of the Regions on Immigration, Integration and Employment. COM (2003) 336 Final. Available online: http://www.webcitation.org/query?url=https $\% 3 \mathrm{~A} \% 2 \mathrm{~F} \% 2$ Feur-lex.europa.eu $\% 2$ Flegal-content $\% 2 \mathrm{FEN} \%$ 2FTXT\%2FPDF\%2F\%3Furi\%3DCELEX\%3A52003DC0336\%26from\%3DIT\&date=2019-04-13 (accessed on 13 April 2019).

Copland, Fiona, and Angela Creese. 2015. Linguistic Ethnography: Collecting, Analysing and Presenting Data. London: Sage.

Council of Europe. 1985. Recommendation No. R (82) 18 of the Committee of Ministers to Member States concerning Modern Languages. Western European Education 17: 10-15. [CrossRef]

Council of Europe. 2001. Common European Framework of Reference for Languages: Learning, Teaching, Assessment. Edited by Council for Cultural Co-Operation, Education Committee. New York: Cambridge University Press.

Council of Europe. 2014. Supporto Linguistico per Rifugiati Adulti: Il Toolkit del Consiglio d'Europa. Sondrio: CSA, Gorgonzola, Available online: http://www.webcitation.org/query?url=https $\% 3 \mathrm{~A} \% 2 \mathrm{~F} \% 2 \mathrm{Frm} . \operatorname{coe}$. int $\%$ 2Fsupporto-linguistico-per-rifugiati-adulti-il-toolkit-del-consiglio-d-e\%2F16808b2cb0\&date=2019-04-18 (accessed on 18 April 2019).

Delaney-Black, Virginia, Chandice Covington, Steven J. Ondersma, Beth Nordstrom-Klee, Thomas Templin, Joe Ager, James Janisse, and Robert J. Sokol. 2002. Violence exposure, trauma, and IQ and/or reading deficits among urban children. Archives of Pedriatic and Adolescent Medicine 156: 280-85. [CrossRef] [PubMed]

Duranti, Alessandro. 1997. Linguistic Anthropology. New York: Cambridge University Press.

Epifani, Federica, and Andrea Forte. 2018. Il quadro socio-demografico della provincia di Lecce. Placetelling Collana di Studi Geografici sui Luoghi e Sulle Loro Rappresentazioni 1: 35-54.

Extramiana, Claire, and Piet Van Avermaet. 2011. Language Requirements for Adult Migrants in Council of Europe Member States: Report on a Survey. Strasbourg: Council of Europe, Available online: http://www. webcitation.org/query?url=https $\% 3 \mathrm{~A} \% 2 \mathrm{~F} \% 2 \mathrm{Frm}$.coe.int $\% 2 \mathrm{FCoERMPublicCommonSearchServices} \%$ 2FDisplayDCTMContent\%3FdocumentId\%3D09000016802fc1d9\&date=2019-04-13 (accessed on 13 April 2019).

Fernández Vítores, David. 2013. El papel de la lengua en la configuración de la migración europea: tendencias y desencuentros. Lengua y migración 5: 51-66. Available online: http://www.webcitation.org/query?url=http $\% 3 \mathrm{~A} \% 2 \mathrm{~F} \% 2 \mathrm{Flym}$.linguas.net $\% 2 \mathrm{FD}$ ownload.axd $\%$ 3Ftype\%3DArticleItem\%26id\%3D116\&date=2019-04-13 (accessed on 13 April 2019).

Forges Davanzati, Guglielmo, and Nicolò Giangrande. 2018. L'economia salentina nella crisi. Un'analisi del mercato del lavoro locale. Placetelling. Collana di Studi Geografici Sui Luoghi e Sulle Loro Rappresentazioni 1: 303-14. 
Galera, Giulia, Leila Giannetto, and Antonella Noya. 2018. The Role of Non-state Actors in the Integration of Refugees and Asylum Seekers. In OECD Local Economic and Employment Development (LEED) Working Papers. Paris: OECD Publishing. [CrossRef]

Goetz, Judith P., and Margareth D. LeCompte. 1998. Etnografía y Diseño Cualitativo en Investigación Educativa. Madrid: Morata.

Hammersley, Martyn, and Paul Atkinson. 2007. Ethnography: Principles in Practice. Ottawa and New York: Routledge.

Jacobsen, Karen, and Loren B. Landau. 2003. The dual imperative in refugee research: some methodological and ethical considerations in social science research on forced migration. Disasters 27: 185-206. [CrossRef] [PubMed]

Kirmayer, Laurence J., Lavanya Narasiah, Marie Munoz, Meb Rashid, Andrew G. Ryder, Jaswant Guzder, Ghayda Hassan, Cécile Rousseau, and Kevin Pottie. 2011. Common mental health problems in immigrants and refugees: general approach in primary care. Canadian Medical Association Journal 183: 959-67. [CrossRef] [PubMed]

Krumm, Hans-Jürgen. 2012. Multilingualism, heterogeneity and the monolingual policies of the linguistic integration of migrants. In Migrations: Interdisciplinary Perspectives. Edited by Michi Messer, Renee Schroeder and Ruth Wodak. Vienna: Springer, pp. 43-54.

Locchi, Maria Chiara. 2012. L'accordo di Integrazione Tra lo Stato e lo Straniero. (Art. 4-Bis T.U. Sull'Immigrazione N. 286/98 Alla Luce Dell'analisi Comparata e Della Critica al Modello Europeo di "Integrazione Forzata". Associazione Italiana dei Costituzionalisti 1. Available online: http://www.webcitation.org/query?url= https $\% 3 \mathrm{~A} \% 2 \mathrm{~F} \% 2 \mathrm{Fwww}$.rivistaaic.it\%2Fit\%2Frivista\%2Fultimi-contributi-pubblicati\%2Fmaria-chiaralocchi\%2Fl-accordo-di-integrazione-tra-lo-stato-e-lo-straniero-art-4-bis-t-u-sull-immigrazione-n-286-98alla-luce-dell-analisi-comparata-e-della-critica-al-modello-europeo-di-inte\&date=2019-04-13 (accessed on 13 April 2019).

Ministero dell'istruzione, dell'università e della ricerca. 2015. Decreto 12 Marzo 2015. Allegato B, Recante le Linee Guida per il Passaggio al Nuovo Ordinamento a Sostegno Dell'autonomia Organizzativa e Didattica dei Centri Provinciali per L'istruzione Degli Adulti. Gazzetta Ufficiale 8 Giugno 2015. Available online: http://www.webcitation.org/query?url=https $\% 3 \mathrm{~A} \% 2 \mathrm{~F} \% 2 \mathrm{Fwww}$.gazzettaufficiale.it $\% 2 \mathrm{Feli} \% 2 \mathrm{Fid} \%$ 2F2015\%2F06\%2F08\%2F15A04226\%2Fsg\&date=2019-04-12 (accessed on 12 April 2019).

Minuz, Fernanda, and Alessandro Borri. 2016. Literacy and language teaching: tools, implementation and impact. Italiano LinguaDue 2: 220-31. [CrossRef]

Minuz, Fernanda, Alessandro Borri, and Lorenzo Rocca. 2016. Progettare Percorsi di L2 per Adulti Stranieri. Torino: Loesher.

Pinson, Halleli, and Madelaine Arnot. 2007. Sociology of education and the wasteland of refugee education research. British Journal of Sociology of Education 28: 399-407. [CrossRef]

Pulinx, Reinhilde, Piet Van Avermaet, and Claire Extramiana. 2014. Linguistic Integration of Adult Migrants: Policy and Practice. Final Report on the 3rd Council of Europe Survey. Available online: http://www.webcitation.org/query?url=https $\% 3 \mathrm{~A} \% 2 \mathrm{~F} \% 2$ Flanguageforwork.ecml.at $\% 2$ FPortals $\%$ 2F48\%2FICT_REV_LFW\%2FLIAM-SurveyReport2014_EN.pdf.pdf+\&date=2019-04-13 (accessed on 13 April 2019).

Rocca, Lorenzo. 2008. Percorsi per la Certificazione Linguistica in Contesti di Immigrazione. Perugia: Guerra Edizioni. Saigh, Philip A., Maria Mroueh, and Douglas Bremner. 1997. Scholastic impairments among traumatized adolescents. Behaviour Research and Therapy 35: 429-36. [CrossRef]

Sergio, Giuseppe. 2011. Un Lasciapassare per L'Italia. La Legge Maroni e L'Obbligo del Test di Italiano per Stranieri. Italiano LinguaDue 1: 53-64. Available online: http://www.webcitation.org/query?url=https $\% 3 \mathrm{~A} \% 2 \mathrm{~F} \%$ 2Friviste.unimi.it\%2Findex.php\%2Fpromoitals\%2Farticle\%2Fview\%2F1228\%2F1440\&date=2019-04-13 (accessed on 13 April 2019).

SPRAR. 2017. Aderire Alla Rete Sprar. La Presentazione Della Domanda per Accedere allo Sprar. 5. Modulo per il Piano Finanziario Preventivo-PFP (Modello C). Available online: http://www.webcitation.org/query?url= https \%3A\%2F\%2Fwww.sprar.it\%2Faderire-alla-rete-sprar-7\&date=2019-04-12 (accessed on 12 April 2019).

SPRAR. 2018. Rapporto annuale Sprar. Roma: Atlante Sprar. 
Valles, Miguel S. 2003. Técnicas Cualitativas de Investigación Social. Reflexión Metodológica y Práctica Profesional. Madrid: Editorial Síntesis.

(ब) (1)

(C) 2019 by the authors. Licensee MDPI, Basel, Switzerland. This article is an open access article distributed under the terms and conditions of the Creative Commons Attribution (CC BY) license (http://creativecommons.org/licenses/by/4.0/). 
Article

\title{
"And Slowly, the Integration and the Growing and the Learning": Nuanced Notions of Integration of Bhutanese Refugees in US Cities
}

\author{
Annie Taccolini Pannagio and Odessa Gonzalez Benson* \\ School of Social Work, University of Michigan, Ann Arbor, MI 48109, USA; annietacc@gmail.com \\ * Correspondence: odessagb@umich.edu
}

Received: 16 April 2019; Accepted: 6 June 2019; Published: 11 June 2019

\begin{abstract}
Policy related to refugee integration focuses on economic factors, while integration is not clearly operationalized nor is it being systematically measured and tracked in policy implementation. This study poses the question, how can local-level integration be conceptualized based on the perspectives of resettled refugees, to add nuance to policy. Using a case study approach with a nation-wide scale, data include 40 interviews and five focus groups with leaders of Bhutanese refugee-run organizations in 35 cities across the United States. Findings illustrate the importance of bonds, bridges and links in non-linear, relational integration. Findings also suggest that better access to services and resources is the responsibility of policy-makers and would lead to stronger bridges over time. This complicates existing policy and implies that resettlement programming should remain individualized and contextual from the ground level to the national level.
\end{abstract}

Keywords: two-way integration; resettled refugees; Bhutanese; resettlement policy

\section{Introduction}

Refugee integration is nebulously defined on the home page of the federal institution of refugee resettlement: "The Office of Refugee Resettlement (ORR) helps new populations maximize their potential in the United States by linking them to critical resources that assist them in becoming integrated members of American society" (US ORR 2019). According to the most recent government assessment of US resettlement policy, "Integration is also a part of ORR's mission and overall goal", and resettlement officials and practitioners "consider integration to be a central aspect of refugee resettlement" (US GAO 2012). ORR "aim(s) to prepare refugees for long-term integration into their communities" (US GAO 2012).

However, at local, on-the-ground levels of policy implementation, "integration" is not clearly operationalized nor is it systematically measured or tracked (US GAO 2012; Brick et al. 2010, p. 15). Non Governmental Organizations (NGOs) and service providers attributed the lack of measurement to having no definition of integration in federal policies that drive programming (US GAO 2012). 'Integration' exists as a concept in policy discourse on websites and in on-the-ground practice, but integration is not an explicit goal of the Refugee Act of 1980, the original refugee resettlement legislation in the United States. Instead, federal resettlement policy specifies self-sufficiency as a desired outcome; while the term 'integration' is not present (Refugee Act 1979). Self-sufficiency as a policy goal means that refugees' employment becomes the focus of frontline workers and practitioners in the field (Darrow 2015, 2018; Gonzalez Benson and Taccolini Panaggio 2019).

The ambiguous policy aim of 'integration' combines with the official policy aim of self-sufficiency, defined as non-dependence on public assistance via employment. Integration then becomes focused on financial issues in both practice and research. In the recent report on integration by the Migration Policy Institute (MPI), the measures of integration were exclusively related to economic 
well-being: on employment, unemployment and underemployment rates, income, and public benefits (MPI 2015). Language abilities and education were also measured but within the context of employment (MPI 2015).

While economic self-sufficiency measures one aspect of integration, it is not all-encompassing and fails to account for complexities related to resettlement and integration. Additionally, this measure may be more tailored to the federal level of programming, without understanding of how local communities integrate new arrivals. The prioritization of economics in resettlement policy may have been necessary to gain political support for acommunity (Gonzalez Benson 2016), but institutional economic priorities may be at odds with the daily lives of particular people placed in particular places. It is unclear how integration in communities and cities compares to definitions of integration that come from policy. This study examines local-level integration from the perspective of resettled refugees, using a case study approach and drawing from theoretical frameworks. The aim is to help fill that gap in refugee policy research in the United States.

This study distinguished between how native-born persons may integrate with new environments throughout their lives. Migrant integration is not examined from the perspective of economic well-being or marginalization from a certain community, but rather, from a broader question of what it means to become part of a new sociocultural space; and how social policy acknowledges and participates in that process.

As mentioned, policy around refugee integration has primarily been preoccupied with economic considerations. This study's main focus is integration at the level of individual refugee experience. By looking at the lives impacted by policy, we can analyze whether that policy is successful or not, and whether it is applied consistently. By examining resettled Bhutanese refugees in the United States, this study compares policy-based notions of integration with ones that are nuanced and evolving, like refugees themselves. The study examines perspectives of Bhutanese refugees as case study, as researchers have positionalities and experience working with this population. Research inquiry focuses upon 'how integration can be conceptualized using Bhutanese refugees' perspectives'. We draw from notions of 'bonds, bridges and links', detailed below, for that conceptualization. Our findings suggest that there is no constant definition of integration, but that the economics-based definitions in resettlement policy are not always what are reflected in the experiences of becoming part of a community. Flexible policy is therefore necessary. Leaders of refugee organizations were consulted for this study, and our conclusion references their experiences and their suggestions. Bhutanese refugees are deemed an effective case study for two reasons: they are present throughout the United States is dispersed, and they are known for their participation in community organizing both in cities and in refugee camps (discussed further below).

\section{Bonds, Bridges, and Links}

Other scholars have challenged an economic emphasis on integration and viewed it instead as a 'two-way' and 'non-linear' experience (Ager and Strang 2008; Atfield et al. 2007; Vrecer 2007). Integration does not assimilate one group into the whole of another group but rather comingles two different perspectives and ways of life to create symbiotic and diverse sociocultural ecosystems (Vrecer 2010). (Ager and Strang 2008) state that the perspectives of both newcomer community and existing society are necessary to avoid the faulty idea of integration as "'insertion' of one group amidst another". Refugees perceive what it means to be in a new nation, and native-born residents consider what it means to welcome new members into a preexisting society.

The 'two-way' approach to research evolved in response to perspectives that discussed integration in a more linear manner. Such research only considered how well refugees acculturated into broader society (Ager and Strang 2008; Malkki 1992; Han 2013; Phillimore 2010) and prioritized longevity of housing and employment (Birgier et al. 2016). By conceptualizing integration as two-way and non-linear, the 'receiving community' is implicated in refugee integration and resettlement with equal weight as the 'entering community'. 
Integration from a mutual partnership or non-linear lens is comprised of three elements: bonds, bridges, and links (Boateng 2010; Strang and Ager 2010). Bridges and links refer to social and cultural relationships that extend beyond the refugee community; bonds refer to relationships within the refugee community. Each element plays a distinct and important role in the integration process (Martone et al. 2014; Cheung and Phillimore 2017), as detailed in our discussion and conclusion. Integration in the extended community is necessary for upward mobility (Cheung and Phillimore 2017). Social capital, or the value associated with relationships in social settings, is important in refugees' sociocultural integration (Boateng 2010; Sime and Fox 2014), although a critique of social capital is also necessary to account for the ways through which social capital for resource-poor communities can also constrain them to within-group social networks (Zetter et al. 2005).

Much research has considered integration as two-way and non-linear. Ager's idea of integration was more intentional in including qualitative narratives from refugees themselves (Ager and Strang 2008; Strang and Ager 2010; Vrecer 2010; Platts-Fowler and Robinson 2015). However, such discussions are largely missing within discussions of refugee resettlement in the United States.

Within the United States, little has been published that specifically speaks to the social and cultural aspects of refugee integration (Tyson 2017). Though there is a rich body of US literature on integration, assimilation, and adjustment (Massey 1981), integration has been largely examined as immigrant integration. Few studies consider refugees, in particular, as a subset of immigrant populations.

The bulk of studies on refugee resettlement in the United States is concerned with policy relevance (Bakewell 2008) and has focused on economic considerations or employment (MPI 2015; Darrow 2015), given that self-sufficiency is the aim of US resettlement policy. Darrow (2015), Smith (2013), and Gonzalez Benson and Taccolini Panaggio (2019) analyze the emphasis on employment by state-contracted refugee-serving organizations. Nevertheless, such studies concern themselves with the economic aspects of integration. Moreover, these studies do not focus on 'integration' —only imply it-when discussing economic considerations. Similarly, other US-based studies also only indirectly examine integration via related topics, such as food (Patil et al. 2010), housing, healthcare, education (Kenny and Lockwood-Kenny 2011), health, and mental health (Birman and Tran 2008). Other studies focus on earlier refugee groups, such as Hmong and Bosnian refugees (Duchon 1997; Grigoleit 2006; Franz 2003), and others focus on native-born perspectives rather than those of refugees themselves (Smith 2013). "There is not much known about integration" (of refugees in the United States), concluded the most recent report commissioned by the US government for examining resettlement. This study aims to address the gap in considering social and cultural aspects of integration.

\section{Methods}

To examine notions of refugee integration at local levels, this paper uses a case study approach with a national scope, focusing on organizational perspectives from key members and leaders of Bhutanese refugee community organizations (RCOs) in cities across the United States.

Case study: Bhutanese refugees. In the late 1980s, the Buddhist-majority government of Bhutan implemented policies that suppressed the culture, language, and belief system of the Nepali ethnic minority group, resorting to violence to implement policy (Rizal 2004). More than 100,000 people fled religious and ethnic persecution in Bhutan and sought refuge in refugee camps in Nepal for two decades. Resettlement began in 2008, and over 80,000 Bhutanese refugees have resettled in hundreds of cities across the United States.

Data and analysis. Data are 40 interviews and five focus groups with leaders of Bhutanese refugee organizations. These organizations include 35 RCOs based in the 35 cities in 30 states where Bhutanese refugees were placed by the US government over 10 years of resettlement. Please see Appendix A for the list of cities and states. The cities where the RCOs included in this study were located include cities in the west, south, northeast, and Mid West regions; large, midsize, and small size cities; long-established resettlement cities and emerging cities of resettlement; and cities that may reflect different political leanings towards refugees (and immigrants). The national scope of data enabled the study to examine 
concepts of integration across various cities and locales. As this study examines only one refugee group, ethnicity was not a factor that needed to be considered. The specific analysis is part of larger research project on the organizational life of Bhutanese refugees.

This study used snowball recruitment, as is common for trying to engage elusive communities, such as refugees (Atkinson and Flint 2001); four Bhutanese RCO leaders initiated contact by identifying participants in their networks. The 40 interviewees and focus group participants were leaders or key members of Bhutanese RCOs. All interviewees and focus group participants were male, spoke English, and had some employment and/or educational experience, and thus had relatively high socioeconomic status (SES). Such characteristics are generally representative of organizational leaders of Bhutanese refugee communities in the United States. A research design that focuses on organizational leaders has advantages and disadvantages. On the one hand, such organizational leaders have access to insights, values, and experiences of community members and are thus able to convey insights from the community. On the other hand, their ideas and experiences only indirectly reflect ideas of individuals and families in the community. That is to say, their organizational perspective may nevertheless privilege their own perspectives as leaders and their own SES status. This limitation justifies further studies that directly capture additional perspectives of refugees, particularly those with lower SES.

Interviews, focus groups, research consultations, and other aspects of research planning were conducted in English, as most Bhutanese refugees who are organizational leaders speak English sufficiently. As such, there was no translation process involved in this study; English language competency was, in effect, a criterion for selecting participants. Nevertheless, transcribed interviews (used as data in this paper) were revised for grammar and comprehension.

Sampling in this study was limited to particular areas and may not be representative of a larger region. Certain states were not included in the study due to recruitment challenges; there were few Bhutanese refugees in those states, and most had relocated to other cities by the time the data was collected. Locating participants in those states and cities was challenging. Furthermore, it was determined that data saturation was reached, and continued data collection for more states was not needed (Guest et al. 2006) had been reached, and recruitment was curtailed. Systematic analysis of city-level and state-level variation were not conducted for this study, and is a limitation. Future studies could explore how perspective — at both the organizational and individual level—may vary depending on location.

The interviews were based on the Guide for Organizational Profile Interviews (Anucha et al. 2006), used for examining refugee organizations (Lacroix et al. 2015). Focus groups expanded on concepts discussed in interviews. The fifth focus group was conducted for member checking (Kidd and Parshall 2000) to discuss and elaborate on initial findings. Participants in the five focus groups were leaders or key members of the five RCOs based in different cities. The first focus group was conducted in the city with the largest number of Bhutanese refugees at the time of data collection. The subsequent four focus groups were based on snowball sampling from these networks. The first author conducted the fifth focus group in 2018 as a second phase of data collection. In 2015, the second author collected primary data used in this study. The first author has worked in the field of refugee resettlement for two years and maintains a relationship with Bhutanese RCOs in one city. The second author, meanwhile, for more than a decade, has worked with Bhutanese RCOs in five US cities, and continues to conduct research with these groups today.

Interviews and focus groups were audio recorded and transcribed, and analyzed using Atlas.ti, which allows for management and analysis of qualitative data. Analysis involved open coding. The second author coded for concepts specified in the Interview Guide as well as other evident concepts. Early on, themes related to social and cultural integration emerged. Second-level coding, conducted by the first author, used an abductive approach (Timmermans and Tavory 2012). Analysis incorporated empirical data and existing theoretical frameworks on integration. 


\section{Results}

The results of the study are sorted into themes, based on an analysis of bonds, bridges, and links. This approach valorizes nuanced definitions of integration as described by participants.

"And slowly, the integration and the growing and the learning, and now I am ok." US refugee resettlement policy primarily focuses on survival needs and employment. Yet, Bhutanese refugees expressed that there is more to their lives in the United States than economic survival. As one participant said,

"You know, the US government has provided us with food, with jobs, with everything that are the basic needs. But that's not all that we need. We need other cultural things, our identities are there, other things that are there: cultural identities, or language, or culture".

The participant refers to "government" at the federal level and in the context of resources provided to all newly arrived refugees upon entering the United States. However, the second part of the participant's quote refers to integration at the local level-where culture, language, and identity play out. This participant's quote succinctly reflects on the disconnection between national policy and local-level integration — what we refer to below as bridges, links, and bonds.

\subsection{Bridges as Individuals, Families, Communities: "Striking the Balance between"}

Gaps between the Bhutanese refugee populations and the larger community can be addressed through bridges-interpersonal connections with people outside one's cultural group. Bridges foster a sense of connectedness and acceptance between people of a region, city, or workplace (Strang and Ager 2010).

Local community events. Community events were suggested as a way to share culture with outside Bhutanese refugee populations. Many participants offered examples of what this process could look like on the local level. One participant shared that in his midwestern city,

"Once or twice a year, there is to be a show, where American people and other immigrants, and Bhutanese and immigrants from other countries, would do the programs together. So that could relate to integration among Bhutanese people and people from other countries including Americans".

Participants often spoke of events like this. Local community events were tangible ways that cultural practices could be both preserved and shared. Another interviewee from a southern city said, "We are organizing multicultural festivals. We invited different people. There was English song being sung by a white person, there was a Spanish song, some Spanish people came, and in Bhutanese also". These events helped local leaders better understand Bhutanese refugees and their needs: "The Mayor was very cooperative, even the city councilmen, by attending the cultural event". Other studies have also found that social events are key to cultural exchange. Studies show that when events, such as cultural expositions and music shows (Lewis 2010), are hosted by refugees and open to the larger community, both parties perceive integration positively (Lewis 2010; Ulack 2013).

Individual and families. Many participants spoke of people who had been particularly helpful and meaningful during the integration process. One RCO leader from a midwestern city shared the story of meeting an American professor in a park. They met because of the professor's dog, but as they talked, they formed a bond that remained with this participant and her family for years. She said of the professor and her family,

"The best part was that [the professor] was happy that my mother, who spoke no English at all, because the professor was helping us every day with that, my mother, she started to speak English, she started going to a job. They helped us find jobs for my mother and they found after school program for me and my brother to go to ... they did pretty much all that for a couple of years and I'll never forget". 
For another RCO leader from a northwestern city (Rhode Island), integration is successful when, for example,

"[People] from the American community come to a Nepali family, sit together for two or three hours, discuss. If there is a language barrier, they will try to have some interpreter. And see how the Nepali family would know how to raise a child in America and the American mom will know how to raise a child in Nepal. So they will know this is how the culture will get exchange and people will learn".

Relationships like this bridged cultural gaps, and created connections. Another participant shared that his wife went to their neighbor's apartment after her husband lost his job, "and she was crying with her and said 'my husband he lose his job and we have to pay. It is day 27 and we have to pay the rent and we don't have money to pay the rent'". The neighbor helped them talk to their landlord and look for new work. This relationship has remained over years, and this participant identifies the neighbor as a key player in their early days in the United States. In this case, the relationship was a connection to the extended community, and a resource during difficult times.

\subsection{Links as Connections to Persons and Institutions: "US Government or Resettlement Agencies Do Not Focus on The Cultural Practices"}

This study also shows how public resources and opportunities help narrow the integration gap. The relationship between a person and their social system can be thought of as links (Ager and Strang 2008), or an individual's connections to institutions and resources (Boateng 2010). Links are strengthened through access to social services and, therefore, equal access to services and programs is necessary for integration of resettled refugees (Strang and Ager 2010; Platts-Fowler and Robinson 2015).

Many participants in our study, however, lacked links. At the institutional level, the cultural values and norms of refugees were not considered. One participant said succinctly that the "US government and resettlement agencies do not focus on the cultural practices". In a midwestern city, one interviewee acknowledged, "[the resettlement agency] is running that class and another job class. but what the organization is providing is not adequate". Another shared, "how can we tell the US government [about our culture]? Still they do not help us, they do not ask". Participants recognized that the broader US systems were not intended to help refugees beyond the basic initial resettlement process. Here, the participant refers to "government" as state-level leadership. One participant had suggested that his RCO presented ideas for better local-level integration programs to state senators or to their governor. Such policy decisions are ultimately federally based, though state and city governments can choose to provide supplementary supports for resettled refugees.

Study participants tended to agree that their collectives had few resources and were often "undermined" by institutional actors, a term that one participant from a northeastern city also used. "I mean, we were very weak in terms of relationships because we were new", that participant shared. Several participants discussed the challenges of trying to form partnerships with governmental agencies and established organizations. Another interviewee said, "I met with the city development authority, with a senator, with a state representative, but did not receive direct help".

The bureaucratic process of pursuing American citizenship was also discussed. Being an American citizen was a point of pride for many participants, making the process even more disheartening when it was un-navigable at local levels. For one participant from a southern city, "national integration" meant being "loyal to the US government and the Constitution"; another participant in a different southern city shared that Bhutanese refugees are "people (who) want to work as American citizens" to "support the law of the land". Indeed, citizenship was a critical institution for integration and belonging, as expressed by one participant:

"One thing that is good in life is now I have become a citizen. Before I was a citizen here, I did not [have] a symbol of any country. Because before in Bhutan, our citizenship was taken. 
In Nepal, we just stayed there without citizenship. Then we came here, we got citizenship and that's good for me".

\subsection{Bonds as Culture and Identity: "Integration Is Not to Lose Everything"}

Bridges and links are key components to integration according to Bhutanese refugee organizational leaders in our study. These connections to the larger community did not translate into a weakening of within-group connections or bonds. As one participant said, "integration is not to lose everything". Integration, he explained, was not about sacrificing deeply rooted parts of one's life, but rather, an opportunity to grow and share with people of all backgrounds.

"Bonds" refers to family connections, networks, and ethnic communities that allow people to "share cultural practices and maintain familiar practices of relationships" throughout the process of integration (Ager and Strang 2008; Strang and Ager 2010). Bonds function as protective factors, especially for newly arrived people adjusting to new routines, such as determining where to buy certain foods and where to worship (Ulack 2013). Sharing mutual experiences was key to the processes of adjustment and familiarization.

Study participants formed bonds through sharing resources, celebrating culture, and building community. Integration that allows groups to maintain individual identity while living in a new place is important. One participant shared, "We want our people to embrace the good things we have ... don't forget, we value our elders, we value our association with our parents. Don't ever, you know, disregard those things". One way to celebrate cultural identity was through events focusing on food, language, dance, music, and other cultural elements. "Every year, we organize cultural activities", one person said. Another participant stated, "Especially kids-we are targeting them [with these activities]; they should know our culture, they should know our language". For one participant, forming a Bhutanese RCO was a way to support others and to facilitate cultural practice: "The purpose [of our organization] was basically to keep everything and everyone in the loop. I mean staying together, helping each other, maintaining the culture, even maintaining the language, the mother tongue".

Bonds assist integration precisely through the sharing a collective journey. Lessons can be learned by forming bonds with those who share a sociocultural background and are also attempting to become part of a new environment. By participating in cultural events and encouraging such bonds, leaders in the community support the integration process in an intimate and effective way (Ager and Strang 2008). As one participant noted, "and slowly, the integration and the growing and the learning and now I am ok".

\section{Discussion}

While federal policy defines integration as self-sufficiency, refugee narratives illustrate nuanced notions of integration at local levels: bridging, linking, and bonding with individuals, families, and communities. These local-level manifestations of integration are missing in federal resettlement policy, which fixates on economics. Bridging also implicates the broader community-the host or receiving community -in the integration process. Focusing on the relational nature of integration offers a more holistic approach to the resettlement experience for both existing and new communities. However, this study illustrates a vulnerability in connections that link the local level with the institutional level. Like studies about particularly marginalized refugees (Boateng 2010), our findings show weak connections between the sociocultural aspects of integration and public resources, and inadequate access to culturally meaningful institutional supports. Conclusions may differ by state or city, as determined by local laws, size of NGOs, or community outreach practices. Other studies point to variations in holistic integration processes in state and local governments; but this study does not compare these differences. Links, as defined by Ager and Strang (2008), are not different in local, state, or national relationships; as such, there is room in the field of refugee studies for research that considers possible differences.

Patterns in the data analyzed here confirm the categorization of bonds, bridges, and links. Participant discussions about relationships fit into those three categories, as they discussed integration. 
Refugees spoke of bonds, bridges, and links without being prompted by researchers. As a whole, participants spoke most of bonds-in family life, celebrations, shared meals, and mutual experiences.

Trends in data showed that relationships that fit in the category of bridges were less common, more likely to be connected to difficult circumstances (i.e., asking a neighbor for assistance), and more often required work or planning (i.e., culture-sharing events). When these relationships were built, however, they proved to be more deeply influential in the integration experience than bonds. While bonds tended to keep individuals connected and content in their routines, bridges moved them into a new understanding of life and a broader knowledge of their new country.

Participant stories about links consistently included negative experiences. Interviewees rarely had positive experiences with the social systems they interacted with during resettlement. These organizations left them struggling, unable to reach a full sense of self-sufficiency, even when they were self-sufficient economically.

\section{Conclusions}

While participants of this study shared stories of their community activities and neighborly relationships, they offered little about bureaucratic support. From a social policy perspective, these non-responses suggest ineffective integration for refugees at the institutional level. Some participants made suggestions about how their communities could be better supported: longer periods of case management, and more time and autonomy to select employment and housing, and more support in building their community centers to facilitate bonds during the integration process. Many refugees seem willing to offer ideas about how the system could work more in their favor, both economically and otherwise.

Taking these suggestions and stories into consideration, we suggest that link relationships could lay a strong foundation for more bridges. According to our data, links are the weakest factor in sustainable integration, according to interviews. Links can create bridges if, through the process of connecting new refugees with community members who are incentivized to help refugees with day-to-day needs. Rather than being a fixed period, the length of case management could be determined by a moment when refugees are properly prepared for autonomous life in the United States. Sociocultural success ('bonds, bridges, and links') could by measured by practices that offer fuller understanding of integration, much like economic success among refugees is currently measured as economic integration. Such measures would allow comparing outcomes by type of program, population, context and time period. This would facilitate not only accountability and effectiveness but also issues of social justice.

These findings provide a US-based application of the two-way, non-linear, and sociocultural concept of integration, used predominantly in European and in global contexts (Ager and Strang 2008). This more robust understanding of integration contradicts current US policy focus, which reduces the needs of entire refugee populations to one economic goal. The participants in this study come from various cities in the United States, and the themes of discussion with participants were influenced by the different cities. This perspective aids both policy makers and community builders in challenging the systems involved in integration. Many participants expressed that the more nuanced and personal aspects of their lives were less valorized than aspects that led to better and faster employment. Instead, refugee resettlement should reflect the permanence and complexity of being in a new space. This study suggests that US policy could better address the needs of refugee populations as they manifest at local levels and evolve through the various phases of resettlement.

While national policy provides standards and mandates for resettlement services, state-level governments are better qualified to determine more specific programming (i.e., private or public administration and public-private partnerships). State governments can also add services by using state funds and by seeking discretionary funding from the national government and private sources. Moreover, cities and private/nonprofit resettlement agencies (that implement federal policy) can supplement services for refugees to aid integration at local levels. Localized policy would result in measurements that evolve with changes as experienced by refugees over time as well. Public programs 
that invest in refugee communities at all levels, including in sociocultural elements could help improve not only employment rates, but well-being for both sides of the two-way process.

Author Contributions: A.T.P. conducted research conceptualization, writing, and analyses. O.G.B. conducted data collection and assisted with analysis and writing.

Funding: Fahs Beck Fund for Research.

Acknowledgments: The authors thank the Bhutanese community for participation, guidance and support for this study.

Conflicts of Interest: The authors declare no conflict of interest.

\section{Appendix A}

List of 35 cities included in study, alphabetically listed by state:

Phoenix, Arizona; Tucson, Arizona; Sacramento, California; Colorado Springs, Colorado; Jacksonville, Florida; Atlanta, Georgia; Boise, Idaho; Moline, Illinois; Kansas City, Kansas; Louisville, Kentucky; Baltimore, Maryland; Lansing, Michigan; St Paul, Minnesota; Las Vegas, Nevada; Concord, New Hampshire; Buffalo, New York; Syracuse, New York; Charlotte, North Carolina; Fargo, North Dakota; Akron, Ohio; Cincinnati, Ohio; Columbus, Ohio; Portland, Oregon; Harrisburg, Pennsylvania; Pittsburgh, Pennsylvania; Providence, Rhode Island; Abilene, Texas; Dallas, Texas; San Antonio, Texas; Seattle, Washington; Burlington, Vermont.

\section{References}

Ager, Alastair, and Alison Strang. 2008. Understanding Integration: A Conceptual Framework. Journal of Refugee Studies 21: 166-91. [CrossRef]

Anucha, Uzo, Nombuso S. Dlamini, Miu Chung Yan, and Lisa Smylie. 2006. Social Capital and the Welfare of Immigrant Women: A Multi-Level Study of Four Ethnic Communities in Windsor. Ottawa: Status of Women in Canada.

Atfield, Gaby, Kavita Brahmbhatt, and Therese O'Toole. 2007. Refugees' Experience of Integration. Vancouver: Refugee Council.

Atkinson, Rowland, and John Flint. 2001. Accessing hidden and hard-to-reach populations: Snowball research strategies. Social Research Update 33: 1-4.

Bakewell, Oliver. 2008. Research beyond the Categories: The Importance of Policy Irrelevant Research into Forced Migration. Journal of Refugee Studies 21: 432-53. [CrossRef]

Birgier, Debora Pricila, Christer Lundh, Yitchak Haberfeld, and Erik Elldér. 2016. Self-Selection and Host Country Context in the Economic Assimilation of Political Refugees in the United States, Sweden, and Israel. International Migration Review. [CrossRef]

Birman, Dina, and Nellie Tran. 2008. Psychological Distress and Adjustment of Vietnamese Refugees in the United States: Association with Pre- and Postmigration Factors. American Journal of Orthopsychiatry 78: 109-20. [CrossRef] [PubMed]

Boateng, Alice. 2010. Survival Voices: Social Capital and the Well-Being of Liberian Refugee Women in Ghana. Journal of Immigrant \& Refugee Studies 8: 386-408.

Brick, Kate, Amy Cushing-Savvi, Samia Elshafie, Alan Krill, M. McGlynn Scanlon, and Marianne Stone. 2010. Refugee Resettlement in the United States: An Examination of Challenges and Proposed Solutions. New York: Columbia University School of International and Public Affairs.

Cheung, Sin Yi, and Jenny Phillimore. 2017. Gender and Refugee Integration: A Quantitative Analysis of Integration and Social Policy Outcomes. Journal of Social Policy 46: 211-30. [CrossRef]

Darrow, Jessica H. 2015. Getting Refugees to Work: A Street-level Perspective of Refugee Resettlement Policy. Refugee Survey Quarterly 34: 78-106. [CrossRef]

Darrow, Jessica H. 2018. Administrative Indentureship and Administrative Inclusion: Structured Limits and Potential Opportunities for Refugee Client Inclusion in Resettlement Policy Implementation. Social Service Review 92: 36-68. [CrossRef]

Duchon, D. A. 1997. Home Is Where You Make It: Hmong Refugees in Georgia. Urban Anthropology 26: 71-92. 
Franz, Barbara. 2003. Transplanted or Uprooted? Integration Efforts of Bosnian Refugees Based Upon Gender, Class and Ethnic Differences in New York City and Vienna. The European Journal of Women's Studies 10: 135-57. [CrossRef]

Gonzalez Benson, Odessa. 2016. Refugee Resettlement Policy in an Age of Neoliberalization: A Policy Discourse Analysis of the Refugee Act of 1980. Social Service Review 90: 515-49. [CrossRef]

Gonzalez Benson, Odessa, and Annie Taccolini Panaggio. 2019. 'Work Is Worship' in Refugee Policy: Diminution, Deindividualization, and Valuation in Policy Implementation. Social Service Review 93: 26-54. [CrossRef]

Grigoleit, Grit. 2006. Coming Home? The Integration of Hmong Refugees from Wat Tham Krabok, Thailand, into American Society. Hmong Studies Journal 7: 1.

Guest, Greg, Arwen Bunce, and Laura Johnson. 2006. How many interviews are enough? An experiment with data saturation and variability. Field Methods 18: 59-82. [CrossRef]

Han, Xiaorong. 2013. Exiled to the Ancestral Land: The Resettlement, Stratification and Assimilation of the Refugees from Vietnam in China. International Journal of Asian Studies 10: 25-46. [CrossRef]

Kenny, Paul, and Kate Lockwood-Kenny. 2011. A Mixed Blessing: Karen Resettlement to the United States. Journal of Refugee Studies 24: 217-38. [CrossRef]

Kidd, Pamela S., and Mark B. Parshall. 2000. Getting the focus and the group: Enhancing analytical rigor in focus group research. Qualitative Health Research 10: 293-308. [CrossRef] [PubMed]

Lacroix, Marie, Michael Baffoe, and Marilena Liguori. 2015. Refugee Community Organizations in Canada: The Margins to Mainstream? A Challenge and Opportunity for Social Workers. International Journal of Social Welfare 24: 62-72. [CrossRef]

Lewis, Hannah. 2010. Community Moments: Integration and Transnationalism at Refugee Parties and Events. Journal of Refugee Studies 23: 571-88. [CrossRef]

Malkki, Liisa. 1992. National Geographic: The Rooting of Peoples and the Territorialization of National Identity among Scholars and Refugees. Cultural Anthropology 7: 24-44. [CrossRef]

Martone, Jessica, Danielle Zimmerman, Maria Vidal de Haymes, and Lois Lorentzen. 2014. Immigrant Integration through Mediating Social Institutions: Issues and Strategies. Journal of Community Practice 22: 299-323. [CrossRef]

Massey, Douglas S. 1981. Dimensions of the New Immigration to the United States and the Prospects for Assimilation. Annual Review of Sociology 7: 57-85. [CrossRef] [PubMed]

Migration Policy Institute. 2015. The Integration Outcomes of US Refugees: Successes and Challenges. Washington: National Center on Immigration Policy.

Patil, Crystal L., Molly McGown, Perpetue Djona Nahayo, and Craig Hadley. 2010. Forced Migration: Complexities in Food and Health for Refugees Resettled in the United States. NAPA Bulletin 34: 141-60. [CrossRef]

Phillimore, Jenny. 2010. Refugees, Acculturation Strategies, Stress and Integration. Journal of Social Policy 40: 575-93. [CrossRef]

Platts-Fowler, Deborah, and David Robinson. 2015. A Place for Integration: Refugee Experiences in Two English Cities. Population, Space and Place 21: 476-91. [CrossRef]

Refugee Act. 1979. Refugee Act of 1979, S 643: Hearing before the Committee on the Judiciary U.S. Senate; Washington: U.S. Govt. Print. Off.

Rizal, Dhurba. 2004. The Unknown Refugee Crisis: Expulsion of the Ethnic Lhotsampa from Bhutan. Asian Ethnicity 5: 151-77. [CrossRef]

Sime, Daniela, and Rachael Fox. 2014. Migrant Children, Social Capital and Access to Services Post-Migration. Children \& Society 29: 524-34.

Smith, Yda J. 2013. Resettlement of Somali Bantu Refugees in an Era of Economic Globalization. Journal of Refugee Studies 26: 477-94. [CrossRef]

Strang, Alison, and Alastair Ager. 2010. Refugee Integration: Emerging Trends and Remaining Agendas. Journal of Refugee Studies 23: 589-610. [CrossRef]

Timmermans, Stefan, and Iddo Tavory. 2012. Theory Construction in Qualitative Research: From Grounded Theory to Abductive Analysis. Sociological Theory 30: 167-86. [CrossRef]

Tyson, Catherine. 2017. Towards a New Framework of Integration in the US. Forced Migration Review 54.

Ulack, Christopher Joseph. 2013. 'Starting from Below Zero': Iraqi Refugee Resettlement and Integration in the United States and Austin, Texas. Austin: The University of Texas at Austin, pp. 146-53. 
U.S. Government Accountability Office (GAO). 2012. Greater Consultation with Community Stakeholders Could Strengthen Program; Washington: Government Printing Office.

U.S. Office of Refugee Resettlement. 2019. Available online: https://www.acf.hhs.gov/orr (accessed on 1 April 2019).

Vrecer, Natalija. 2007. Integration as a Human Right: Forced Migrants from Bosnia-Herzegovina in Slovenia. Ljubljana: Scientific Research Centre of the Academy of Arts and Sciences and Slovenian Institute for Adult Education.

Vrecer, Natalija. 2010. Living in Limbo: Integration of Forced Migrants from Bosnia and Herzegovina in Slovenia. Journal of Refugee Studies 23: 484-502. [CrossRef]

Zetter, Roger, David Griffiths, and Nando Sigona. 2005. Social Capital or Social Exclusion? The Impact of Asylum-Seeker Dispersal on UK Refugee Community Organizations. Community Development Journal 40: 169-81. [CrossRef]

(C) 2019 by the authors. Licensee MDPI, Basel, Switzerland. This article is an open access article distributed under the terms and conditions of the Creative Commons Attribution (CC BY) license (http://creativecommons.org/licenses/by/4.0/). 
Article

\title{
The Syrian Canadian Sports Club: A Community-Based Participatory Action Research Project with/for Syrian Youth Refugees
}

\author{
Daniel B. Robinson ${ }^{1, *}$, Ingrid M. Robinson ${ }^{1}$, Vanessa Currie ${ }^{2}$ and Nathan Hall ${ }^{3}$ \\ 1 Faculty of Education, St. Francis Xavier University, Antigonish, NS B2G 2W5, Canada; irobinso@stfx.ca \\ 2 International Institute for Child Rights and Development, Victoria, BC V8W 3G9, Canada; \\ vanessa.anne.currie@gmail.com \\ 3 Faculty of Education and Faculty of Kinesiology and Applied Health, University of Winnipeg, Winnipeg, \\ MB R3B 2E9, Canada; na.hall@uwinnipeg.ca \\ * Correspondence: drobinso@stfx.ca; Tel.: +1-902-867-5569
}

Received: 13 March 2019; Accepted: 21 May 2019; Published: 28 May 2019

\begin{abstract}
In this paper, we share the rationale, process, and results related to a community-based participatory action research (PAR) project in which we, among other things, aimed to attend to the underrepresentation of newcomer youth in community sport and recreation pursuits. By way of engaging with one rural county's Syrian youth refugee population while also attending closely to a social ecological framework, we first identified obstacles and opportunities related to multiple systems (i.e., individual, social/interpersonal, organizational/community, public policy). Drawing upon multiple data sources (i.e., photos and photovoice, participants' drawings and notes, participant-researchers' field notes, and focus group interviews) to inform our subsequent plan-act-observe-reflect action research cycles, we and our Syrian youth participants co-created and implemented the Syrian Youth Sports Club. In addition to describing the rationale and process related to this Syrian Youth Sports Club, we focus herein upon the results, which primarily relate to participants' experiences becoming (physically literate) and belonging.
\end{abstract}

Keywords: participatory action research (PAR); refugee; youth; newcomer; physical activity; sport; recreation; social ecological; ecological systems; physical literacy

\section{Introduction and Background}

By way of developing a new national physical activity resource for newcomer youth, Canada's premier physical and health education organization, Physical and Health Education Canada, recently signaled its recognition of the importance of facilitating sport and recreation participation for all (Stanec and Bhalla 2015). Relatedly, Sport Canada has also recently identified the role sport participation plays in building community. Indeed, one of Canadian Sport Policy 2012's goals is related to sport for development (Sport Canada 2012). Such recognition is to be both expected and celebrated. That is, Canada was the first country to adopt multiculturalism as an official policy, its newcomer population is both diverse and growing (Tremblay et al. 2006), and the many benefits associated with sport and recreation are routinely recognized (Eime et al. 2013; Holt et al. 2011). Additionally, newcomer youth have been found to be less engaged in sport and recreation pursuits than their native-born peers (Tremblay et al. 2006; van Wel et al. 1996; van Wel et al. 2006). Certainly, given these observations, gaining an understanding about newcomer youth's relative (dis)engagement with these active pursuits is especially important. Indeed, if one ascribes to the belief that all youth within Canada, including those who are newcomers, would benefit from and ought to be afforded inviting opportunities for sport and recreation participation, then clearly much is still to be learned, and done. 


\subsection{Relevant Research Related to Newcomer Youth Sport and Recreation Participation}

The challenges and issues that serve to limit newcomer youth participation in sport and recreation pursuits are complex, interconnected, and diverse. Evidence is plentiful suggesting low levels of engagement in sport and recreation for all newcomers (Brewer and Kimbro 2014; Singh et al. 2008), particularly when compared to the engagement of others. Numerous contextual elements may contribute to these lower levels of participation. For example, newcomer youth may live in neighborhood environments lacking suitable and/or inviting environments for such opportunities (Lichter 2013; Yen and Kaplan 1999). Moreover, immigrant "enclaves" (Portes and Rumbaut 2001), neighborhoods with high concentrations of newcomers from the same region or ethnic group, may impact sport and recreation participation in both positive and negative ways (Brewer and Kimbro 2014; Fernandez-Kelly and Schauffler 1994; Logan et al. 2002; Portes 1998). In addition to the physical environment, newcomer youth are also influenced by their social environments whereby, for example, social cohesion and parents'/guardians' safety fears may have a negative impact upon sport and recreation participation (Kimbro and Kaul 2016). Cultural norms and religious beliefs may present additional influencers upon sport and recreation participation (Culp 2010; Robinson and Randall 2016; Stanec et al. 2016). For instance, evidence suggests some female newcomer youth who are Muslim face a greater number of hurdles than do their male peers with respect to sport and recreation participation (Dagkas et al. 2011; Robinson and Randall 2016; Stanec et al. 2016).

That newcomer youth in Canada (and the West) are underrepresented in sport and recreation pursuits (Dogra et al. 2010; Tremblay et al. 2006) suggests that current sport and recreation programs and places are lacking in cultural diversity, if not also in cultural responsiveness (Livingston and Tirone 2012; Robinson et al. 2013). This is not completely unexpected, as a lack of cultural diversity and/or responsiveness and the related negative effect upon participation has been reported in organizations such as Scouts Canada and the YMCA (Van Ngo 2009). This underrepresentation has many potentially undesirable consequences. For example, without adequate participation in sport and recreation, newcomer youth are less likely to develop aerobic and anaerobic fitness (Thivel et al. 2011), competency in motor skill development and performance (Loprinzi et al. 2012), and self-esteem (Erkut and Tracy 2002). They are also more likely to develop anxiety and depression (Goldfield et al. 2011; Sallis et al. 2000). In addition to these physical and emotional consequences, sport and recreation participation has the potential for some positive social and cultural outcomes for newcomers too. That is, with their engagement in sport and recreation, newcomer youth gain opportunities for social integration (Taylor and Doherty 2007), language development and cultural orientation (Doherty and Taylor 2007), a sense of belonging and inclusion (Spaaij 2015; Tirone et al. 2010), and the development of social capital for a new country (Spaaij 2012; Walseth 2008).

\subsection{Recognizing a Need for Our Participatory Action Research (PAR) Project}

Attending to these (and other) observations, opportunities, and challenges necessitates a clearer understanding of the many systems that have an impact upon newcomer youth. For example, in addition to newcomer youth attitudes and behaviors, community and social structures also enable and/or limit opportunities for sport and recreation participation. Certainly, the reciprocal interplay among individual, social/interpersonal, organizational/community, and public policy systems influence opportunities for sport and recreation participation (Strack et al. 2010). The many elements within these four systems can clearly have both positive and negative effects upon newcomers' participation in their newfound sport and recreation places and programs (see Figure 1). For example, an individual's sex can enable or prevent one from participating in sport or recreation. Similarly, one's access to, or knowledge of, local clubs and/or programs can do the same.

The current context is one in which many would benefit from improved and shared knowledge, understanding, and action related to the sport and recreation pursuits of newcomer youth in Canada. Recognizing this, we contacted community partners actively engaged with the Syrian community (this included one of the invited participant-researchers, who had then developed relationships with 
members of the Syrian community through her volunteer work). With the assistance of these community partners, all Syrian youth in the surrounding area were invited to be involved in the project. Those who were interested and obtained parent/guardian approval participated. Through this partnership, we established a community-based PAR project that could address the underrepresentation of these youth in their new community's sport and recreation programs. It is from this community-based PAR project that we and our Syrian youth participants were enabled to co-create and implement the Syrian Youth Sports Club.

\begin{tabular}{|c|cc|}
\hline & $\begin{array}{c}\text { public policy } \\
\text { (or macrosystem) }\end{array}$ & •laws, policies, regulations \\
\hline & $\begin{array}{c}\text { organizational/community } \\
\text { (or mesosystem) }\end{array}$ & $\begin{array}{l}\text {-clubs, local programs, neigborhoods, } \\
\text { partnerships, schools }\end{array}$ \\
\hline $\begin{array}{c}\text { social/interpersonal } \\
\text { (or microsystem) }\end{array}$ & $\begin{array}{l}\text {-culture/religion, friends, } \\
\text { parents/guardians, siblings, social } \\
\text { supports, teachers }\end{array}$ \\
\hline individual & $\begin{array}{l}\text {-age, attitudes/beliefs, ethnicity/race, } \\
\text { socioeconomic status, sex, self-efficacy, } \\
\text { skills /abilities }\end{array}$ \\
\hline
\end{tabular}

Figure 1. Four systems (individual, social/interpersonal, organizational/community, public policy) of the social ecological model, with specific examples for each level.

\section{Methods}

\subsection{PAR}

Action research includes four "moments" that are dynamic, interconnected, and cyclical: plan, act, observe, and reflect (Kemmis et al. 2004) (see Figure 2). PAR is a type of action research that is people-centered, power-conscious, and action-oriented (Kemmis 2006; Sohng 1996); the use of this research methodology can be seen in numerous studies related to sport and physical activity (e.g., see Ferkins et al. 2010; Frisby et al. 2005; Sherry et al. 2017). PAR is somewhat unique in that it offers "research participants" the opportunity to create the conditions for themselves to actively develop forms of action that are in response to their own unmet needs or undesirable conditions, while also building and establishing genuine communities of practice (Kemmis et al. 2014). PAR is also often unapologetically critical whereby, for example, those who engage in it are called upon to recognize and identify "unwelcome truths" (Kemmis 2006, p. 459). Engaging in this sort of inquiry, then, required us (i.e., the participant-researchers) to: (1) welcome our youth participants as genuine partners in the process; and (2) maintain our critical position, even while aiming for, observing, and reporting on the successes of the Syrian Youth Sports Club.

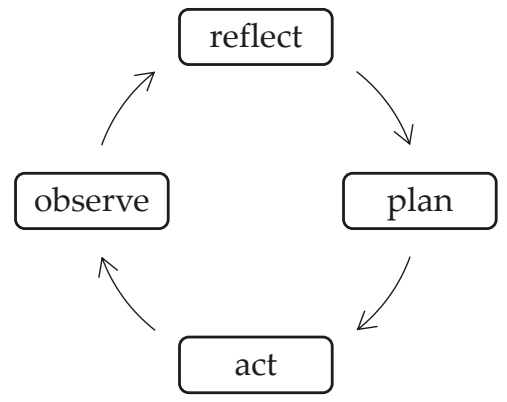

Figure 2. Four moments of action research (plan, act, observe, reflect). 


\subsection{Procedures}

This community-based PAR project included three stages (see Table 1). Methodological procedures from the International Institute for Child Rights and Development's child-centered PAR were used to develop the key steps of the process (Currie and Heykoop 2011). During Stage 1, we participant-researchers spent six full mornings with our Syrian youth participants. This time was largely spent establishing "buy-in" from the youth. Previous relationships between one of the participant-researchers and many of the youth eased the transition to establishing group trust. As well, three of us organized and participated in activities such as leadership games and creative pursuits in order to foster relationships between ourselves selves and the youth. Also in Stage 1, we spent time engaging in initial photovoice and focus group interview sessions, identifying (and addressing) obstacles and opportunities related to sport and recreation participation, and designing a four-season sport and recreation schedule. Action research at this stage was focused, primarily, upon reflection and planning. During Stage 2, Syrian youth participants engaged in their four seasons (tennis, paddling, swimming, basketball) while also attending additional meetings (where photovoice and focus group interview sessions, among other tasks, continued). Action research at this stage was focused on all four steps. Finally, at the conclusion of the four seasons, Stage 3 included four additional meetings in which reflection and planning continued as most or all of participants again engaged in photovoice and focus group interview sessions. Participants who took part in the photovoice and focus group interview sessions were not separated by age or sex due to the strength of the relationships amongst the youth.

Table 1. Overview of stages, dates, PAR steps, specific activities, and participants and partners.

\begin{tabular}{|c|c|c|}
\hline Stages, Dates, PAR Steps & Specific Activities & Participants, Partners \\
\hline $\begin{array}{l}\text { Stage } 1 \text { Dates: July 2018-August } 2018 \\
\text { PAR Steps: reflect, plan }\end{array}$ & $\begin{array}{l}\text { community buy-in, training, } \\
\text { picture taking, photovoice, } \\
\text { interviews, program planning (6 } \\
\text { meetings total) }\end{array}$ & $\begin{array}{l}\text { Participants: } 10 \text { youth participants, } 3 \\
\text { participant-researchers } \\
\text { Partners: local Syrian support group, } \\
\text { provincial sport and recreation } \\
\text { organization, town adult learning } \\
\text { association, town library }\end{array}$ \\
\hline $\begin{array}{l}\text { Stage } 3 \text { Dates: January } \\
\text { 2019-March } 2019 \\
\text { PAR Steps: reflect, plan }\end{array}$ & $\begin{array}{l}\text { photovoice, interviews, future } \\
\text { program planning and reflection } \\
\text { meetings, youth dissemination (4 } \\
\text { meetings total) }\end{array}$ & $\begin{array}{c}\text { Participants: } 9 \text { youth participants, } 3 \\
\text { participant-researchers } \\
\text { Partners: local schools, provincial sport and } \\
\text { recreation organization, town library }\end{array}$ \\
\hline
\end{tabular}

\subsection{Participants and Partners}

A number of participants and partners were involved in this community-based PAR project. The youth participants included the following: (1) nine relatively new-to-Canada Syrian youth refugees who regularly participated in all stages of this project (one additional Syrian youth refugee participated in the initial stage only and is, consequently, not listed here); and (2) seven additional youth visitors who were friends or siblings of some of those in the Syrian Youth Sports Club (three of whom were also Syrian and Muslim, as well as two others who were Muslim). Regular participants were invited to bring friends and/or siblings to the various activities, as they wished. However, only the "regular" youth participants of the Syrian Youth Sports Club who were present for all three stages participated fully in the action research project (the others only participated in some of the activities). Nonetheless, 
all youth participants are listed below (see Table 2), with their name (pseudonyms are used), sex, age, grade level, project status (regular/visitor), and seasons in which they participated.

Table 2. Overview of youth participants (name, sex, age, grade, regular/visitor, seasons).

\begin{tabular}{cccccc}
\hline Name & Sex & Age & Grade & Regular/Visitor & Seasons \\
\hline Aaila & Female & 8 & 2 & Regular & T, S, B \\
Aabid & Male & 9 & 3 & Regular & T, P, S, B \\
Wafiq & Male & 11 & 5 & Regular & T, P, S, B \\
Yasmine & Female & 11 & 6 & Regular & T, P, S, B \\
Nazra & Female & 12 & 7 & Regular & T, S, B \\
Mahia & Female & 14 & 7 & Regular & T, P, S, B \\
Dema & Female & 14 & 8 & Regular & T, P, S, B \\
Šha & Female & 15 & 10 & Regular & T, P, S, B \\
Bahira & Female & 19 & 12 & Regular & T, B \\
\hline Yahya & Male & 10 & 4 & Visitor & S, B \\
Haamid & Male & 10 & 4 & Visitor & S, B \\
Nijat & Male & 11 & 4 & Visitor & S, B \\
Ping & Male & 11 & 5 & Visitor & B \\
Serap & Female & 13 & 7 & Visitor & P \\
Ella & Female & 13 & 8 & Visitor & T \\
Maha & Female & 14 & 8 & Visitor & P \\
\hline \multicolumn{5}{c}{ Note: T tennis; P = paddling; S swimming; B basketball. } &
\end{tabular}

Additionally, other than the three participant-researchers who participated in this project, a number of additional partners were involved. These others included various organizations and those organizations' individuals; these organizations/individuals supported the Syrian Youth Sports Club in many different ways. These organizations/individuals included the local library, recreation departments, and a community organization for newcomer Syrian families, as well as local physical activity leaders who led the four seasons' activities. Two participant-researchers led the tennis, a university instructor/paddling society leader and his students led the paddling, three aquatics instructors led the swimming, and the local university's varsity coaches and players led the basketball. Identifying and welcoming these many community partners was an intended and purposeful decision on the part of us, the participant-researchers.

\subsection{Data Collection and Analysis}

Data were collected through the following data sources: (1) photos and photovoice; (2) participants' drawings and notes; (3) participant-researchers' field notes; and (4) focus group interviews. Photos were shared with the participant-researchers in all three stages; at these sessions photovoice conversations were audio-recorded and transcribed. Participants' drawings and notes were either kept or copied. Field notes were recorded during and/or after meetings and activity sessions. Six focus group interviews were audio-recorded and transcribed.

Thematic analysis (Bernard and Ryan 1998; Boyatzis 1998) was employed to analyze the data. All texts (i.e., participants' drawings and notes, participant-researchers' field notes, transcribed photovoice and focus group interviews) were examined and grouped into themes. An initial participant-researcher coded and categorized textual data as they related to themes according to methods outlined by both Creswell (2012) and Miles et al. (2014). Subsequently, a second participant-researcher engaged in the same exercise. All results are shared only as these two participant-researchers had a $100 \%$ agreement about the coded and categorized primary themes.

\subsection{Ethical Approval}

All research protocols for research involving human subjects were observed. The participant-researchers' universities' Research Ethics Boards (REBs) found that this research was 
in full compliance with Canada's Tri-Council Policy Statement: Ethical Conduct for Research Involving Humans. Though not a requirement, as a courtesy we also shared the research protocols with local partners invested in the group of participants.

\section{Findings}

\subsection{Initial Identification of Obstacles and Opportunities}

Youth participants were encouraged to identify obstacles and opportunities related to "me" (individual), "family/friends" (social/interpersonal or microsystem), and "school/community" (organizational/community or mesosystem) through the use of participatory tools such as photo-voice, risk and resource mapping, and walking tours. In using these practices, they explored the challenges that prevent or hinder their involvement in community sports and recreation. They also identified supports that exist that enable them to participate in such programming in their communities. Through a consideration of the youth participants' photographs/photovoice, their own notes and drawings, transcribed focus group interviews, and our own field notes, a number of obstacles and opportunities were identified within multiple systems.

Within respect to the individual (i.e., "me"-individual), identified obstacles were related to the following: (1) perceived limitations in skills/abilities (e.g., "I do not know how to canoe" and "teachers only explain the game but they don't really work with you to teach you the skills of how to play"); (2) restrictions related to sex (e.g., "I am a girl" and "it is better to only have girls in gym class"); and (3) constraining attitudes/beliefs (e.g., "I can't play because sometimes I should study" and "I can be lazy"). Within the microsystem (i.e., "family/friends"-social/interpersonal), obstacles were related to the following: (1) cultural/religious restrictions (e.g., "I can't swim with boys because of my culture" and "when I am older I am not going to wear the same clothes when I am outside doing sports"); (2) inactive friends (e.g., "I don't have friends who encourage me now" and "my friends don't do these things"); and (3) non-encouraging siblings and parents/guardians (e.g., "sometimes parents don't allow you to have permission [to participate]" and "my parents don't really encourage me to join but they allow me to try things"). Within the mesosystem (i.e., "school/community"-organizational/community), obstacles were related to the following: (1) invisible/inaccessible community programs (e.g., "I don't know how to sign up for anything here" and "they don't tell us where to join"); and (2) limited access to physical activity spaces (e.g., "I don't have a pool" and "I don't have a membership to places").

Though these obstacles were identified, youth participants were also able to identify a number of opportunities that existed within these same systems. For example, with respect to the individual, opportunities were related to the following: (1) enabling attitudes/beliefs (e.g., "I like PE [physical education]" and "I like to be active and I know that it is important to be strong and healthy"); and (2) positive self-efficacy (e.g., "I am sporty" and "I am good at basketball"). Within the microsystem, opportunities were related to the following: (1) supportive Syrian friends (e.g., "Dema, Mahia, Nazra all will do things with $m e$ " and "friends help you and make you feel comfortable"); (2) supportive siblings and parents/guardians (e.g., "my family tells me to go [do sports/activities] if I want to" and "my sister and my parents support me [to be active]"); and (3) emerging allies (e.g., "you three [leaders] are helping us do things" and "Dan, Vanessa, and Ingrid will help us").

With this information in hand, we participant-researchers were able to co-create with the Syrian youth a grant-funded program that addressed these obstacles and embraced these opportunities. For example, to address obstacles, we purchased all necessary equipment, booked community gymnasium space, recruited sport and recreation instructors, organized all transportation, and completed most necessary paperwork for parents/guardians. Similarly, to embrace opportunities, we allowed the Syrian youth to choose the four activities, we limited most sessions to their own Syrian peer group, and we maintained our roles as allies to them (e.g., by attending all activity sessions). 


\subsection{On Becoming (Physically Literate) and Belonging}

During the four seasons of tennis, paddling, swimming, and basketball, and in a number of meetings afterwards, youth participants met with us to discuss their experiences in the Syrian Canadian Sports Club. Through the continued use of photovoice and focus group interviews, two emergent themes were identified: becoming (physically literate) and belonging.

\subsubsection{Becoming (Physically Literate)}

Physical literacy, as it is most widely conceptualized, is the "motivation, confidence, physical competence, knowledge, and understanding to value and take responsibility for engagement in physical activities for life" (Edwards et al. 2017, p. 113). The many parts of this multi-dimensional physical literacy construct are oftentimes framed as affective (motivation and confidence), physical (physical competence), cognitive (knowledge and understanding), and behavioral (lifetime engagement) (see Robinson and Randall 2017; Robinson et al. 2018). Given the earlier mentioned initial impetus of this community-based action research project (i.e., to address the underrepresentation of Syrian youth refugees in community sport and recreation pursuits), a consideration of the Syrian Youth Sports Club experience upon participants' lifecourse physical literacy journeys is both logical and warranted.

All youth participants made many mentions of how their participation in the Syrian Youth Sports Club impacted their motivation, confidence, physical competence, knowledge, and understanding to value and take responsibility to be active for life. Consider, for example, the following physical literacy-related sentiments shared by the youth participants.

Related to motivation and confidence (affective), participants spoke about becoming able to overcome their initial shyness and insecurities so that there were enabled to become more active:

[Before I started] I felt of kind of shy to be active because when I was at school people would be better than me because I never took sports in Syria. I just felt like I was being shy. (Dema, 14)

Before I never really did anything. I never really liked sports before we started this but, now, I really do. Now I am excited. I'm not shy or scared now. I am excited to do sports. (Yasmine, 11)

Given our field notes' common observation that some of the youth were observably much more engaged as the various seasons progressed, we offered some prompting questions about this phenomenon. Consider, for example, the following exchange:

I was watching you all every day. And, for some of you, something seemed to change. You did not look the same near the end of a season. Can somebody comment on that? (Researcher)

The first day when I came back home, I was like, "No, I do not like basketball at all. I don't want to keep playing." But then, I really liked it and I wanted to come. (Dema, 14)

I just liked it more and more when I got better. Now it is easier and I am not so embarrassed. (Mahia, 14)

The youth participants also shared accounts of how this newfound motivation and confidence allowed them to be viewed differently by their non-Syrian peers at school:

It feels a lot better and you get to be known as a sports player because you ... it kinds of feels cool to say that you are playing basketball and other sports that you would not think you'd be playing. (Mahia, 14)

Related to physical competence (physical), the youth participants recognized the areas in which they believed they had improved. These improvements were related to their sport-specific skills in all four movement experiences: 
I think I am really good at basketball because I was a really good shooter and I can be like that sometimes. (Šaha, 15)

I got better at playing tennis and basketball. (Wafiq, 11)

I got better at all the sports because I now know how to canoe and play tennis and how to use racquets. And, not just for tennis. But for badminton too. And pickleball. (Aabid, 9)

For swimming, when I was not wearing a scarf, I was swimming in the pool but I was just in the shallow end. But, when we did this, when I swam in the deep end and I did swim without anything and it was amazing. I never knew I could do that. I never could do it before. (Mahia, 14)

Related to knowledge and understanding (cognitive), the youth participants were able to share the perceived benefits they received from being physically active in these various seasons. They came to know, and/or feel, that their sport and recreation participation impacted their affect in a number of manners:

Each time when we play sports after we are done, I feel better. I feel better. I feel like I want to do more things. I feel more active. (Nazra, 12)

I feel happy because I have learned a lot of stuff that I never thought before. (Mahia, 14)

I'm happy and proud. I am proud of myself, but I am proud that we did learn stuff and I did learn. (Dema, 14)

I feel energized in basketball, tennis, and swimming. In all the things we did. (Aabid, 9)

Related to engaging in physical activities for life (behavioral), participants spoke of how, only after participating in a season, they began to engage in similar activities when they were without the Syrian Canadian Sports Club. These accounts offered insight into how their Syrian Youth Sports Club participation was positively influencing their ongoing physical activity in their community:

After we learned things in one of our seasons, did any of you ever do those things on your own time? (Researcher)

Yes, me and Dema. We usually would go to the park and all the families go. And, we go now and play [tennis]. In summer we are going to go every day. (Mahia, 14)

Me, I now practice at the basketball courts. (Nazra, 12)

Did you practice basketball before we did it together? (Researcher)

No! (Nazra, 12)

And, so, what has changed? (Researcher)

I got a lot better and it feels like it is so much easier now. It is easier in the short basketball court too. I never thought I could score on the first try [but I do now]. (Nazra, 12)

And, now, after school we bring our basketballs to school on Friday and practice in the gym after school. From 3:00 until 5:00. (Mahia, 14)

And now I want to be on the [school] basketball team. Actually, I am now. (Šaha, 15) 


\subsubsection{Belonging}

While the Syrian Youth Sports Club may have been a co-created experience that materialized as the primary product of the community-based PAR project, the youth participants' experiences offered more than sport and recreation opportunities. That is, while they may have been enabled to move along on their physical literacy lifecourse journeys, there were other, arguably more important, outcomes here. More specifically, the youth participants spoke of how the Syrian Youth Sports Club afforded them opportunities to feel more involved and included within their new Canadian community. Consider the following, for example:

The best days are when we started. When we all met together, here [in the library]. The first day was the best day when we started the group. Until we ended, it's all a good thing. Every day together has been a good day. (Nazra, 12)

These have been the best days of my life. (Yasmine, 11)

Yeah, I am now involved. (Dema, 14)

What do you mean you are now involved? (Researcher)

Well, before we made the group [Syrian Canadian Sports Club] we did not really play that much sports. Here [in Canada], if you ask anybody, they play something. We did not play anything when we came here. If they asked me, I did not play anything. But now I do. Now, I just can play. I am now involved. (Dema, 14)

Involved in? (Researcher)

The community. (Dema, 14)

And, how do you all see yourselves as athletes in your new community? (Researcher)

Proud! I feel proud. It feels really good to know how to do all these sports now. Before, I said I never thought I would be doing these sports in the future. It is crazy. (Mahia, 14)

What about everybody else? Has this experience changed how you feel in your community? (Researcher)

I feel more involved too. And, more as a team. (Šaha, 15)

I feel more welcome. (Aabid, 9)

I feel like a Canadian. (Yasmine, 11)

I feel more Canadian because Canadian people do a lot of sports. They know everything. Syrian people, especially girls, they don't do any sports. And, now, I feel that I am more Canadian and that's the thing I am proud of. (Mahia, 14)

Additionally, not only did the youth participants feel that they were more a part of their new community, but they also saw that they could soon play a role in making others feel welcome too:

Because this community and program help us to learn those sports, I would like to do the same thing for people. (Dema, 14)

I would like to make people feel involved and welcomed in everything like how you made us feel.

(Mahia, 14)

Especially shy girls. (Dema, 14) 
Especially girls. In Syria, we would like to also make that program thing and we could. A lot of girls cannot play because of culture and things. We could just create a program [here] for girls and help them be active and play some sports. (Šaha, 15)

At about the same time, the Syrian Canadian Sports Club was featured in the local newspaper, and youth participants shared the pride they had when their teachers took notice:

My teacher said, "I saw you in the newspaper today." And he was really proud [of me]. He asked me if he could read it [to the class]. I said, "yes" and do he did. (Wafiq, 11)

A teacher at the school said she saw me in the newspaper and she asked me if I had the newspaper. She said, "come with me because I have a lot of them" and she gave it to me. (Nazra, 12)

\subsection{Newfound and Unanticipated Difficulties}

The Syrian Youth Sports Club was not without difficulties. Two newfound and entirely unanticipated difficulties highlighted others' cultural ignorance and cultural insensitivity. Both of these were related to the youth's participation in swimming.

With respect to cultural ignorance, the swimming season required a number of purposeful actions to address various obstacles, most of which were related to the intersecting identities of sex, religion, and culture. For example, the following actions were undertaken: (1) the female and male participants were split for swimming sessions; (2) the entire pool was booked for the female youth's swimming sessions; (3) burkinis were purchased for all female participants who wore hijabs; (4) curtains were placed inside pool windows to prevent observers from seeing the female participants while they were in the pool, and (5) all lifeguards/instructors for the female participants were female. Notwithstanding the positive intentions related to all of these efforts, on one occasion, female lifeguards/instructors invited a male lifeguard/instructor onto the pool deck despite clear instructions to never do so. Given the presumed safe environment (i.e., girls/women only, curtains, etc.), some of the female youth participants had uncovered their hair by taking the hoods off of their burkinis. When the male lifeguard/instructor entered the pool deck, he and the female lifeguards/instructors were ignorant of the grossly uncomfortable environment they had just created. Their ignorance had both an immediate and continued negative impact on the female participants. In response to this event, the institution's aquatics supervisor, as well as the female and male lifeguards/instructors, provided a letter of apology to the participants and their parents/guardians. Still, the damage was done.

With respect to cultural insensitivity, an anonymous community member submitted an article (that was effectively a letter of complaint) to Frank (a provincial scandal/satirical magazine) near the end of the swimming season. While we were made aware of this article only by chance, the contents within in point to the insensitive and arguably xenophobic attitudes that lurk in the shadows within the community. Consider, for example, the anonymous contributor's own words:

And then I discovered the real scandal that prompted me to write a letter of protest .... I was shocked to see the usual window completely covered by an opaque black curtain. I asked at the desk what was going on and was told it was a "private function." Several people I know noticed it too, and it became clear that it was a regular arrangement for Muslim women to swim without being seen by anybody, particularly anybody male ... . In Canada, women don't need to hide to go to the pool. Our community is very tolerant: everybody frequents the pool, all ages, handicapped people, and usually nobody wants to hide. What kind of integration are these women trying to achieve?... I don't say this out of any anti-immigrant feelings, but because I am convinced that we live in a rather good society and that newcomers should do their best to integrate into it. (2019, p. 32)

This anonymous author seemed to be unaware that many single-sex (i.e., for women) physical activity opportunities exist throughout the community. Indeed, such an accommodation is a normal feature of many sport and recreation programs for women here and elsewhere. The differences here 
are that our participants were youth (and children) rather than women (though she/he did not know that) and that they were also all Syrian Muslims. Consequently, we assume that cultural insensitivity to our participants' intersecting religious and cultural identities was what was really at play here. This othering of our youth participants was certainly a most disappointing occurrence. It is not possible to draw conclusions about the prevalence of racism within the community, but this article indicates that some portion of the population certainly holds these beliefs.

\section{Discussion}

The obstacles and opportunities that we identified and then addressed or embraced are somewhat familiar within the literature. At the same time, some of these obstacles and opportunities are also somewhat exclusive to our unique context. Or, otherwise said, place matters. With respect to the environment, for example, our site has physical and social obstacles and barriers that are unique to this place and time. Because the youth participants do not live in immigrant enclaves (Portes and Rumbaut 2001), they are neither enabled nor limited by that. Their rural towns are small ones. In the larger of the two towns, virtually any sport or recreation space is accessible by foot. That is, the youth participants could walk to the tennis courts, swimming pool, or basketball courts. Yet, before the advent of the Syrian Youth Sports Club, none did. While the physical environments were always there, they were not being accessed-or, were not actually accessible.

So, how is it that these Syrian youth had access to the spaces but did not actually access them? In order for these sorts of spaces to be welcoming to those who show up in the community already being othered, more is needed. For example, sport and recreation programs' usual methods of communication and recruitment are aimed at the "normal" Canadian child/youth/family. This is true of language, media messaging, fees/costs, and entry stages. However, not all newcomers can speak English, can access social media sources (e.g., Facebook), can afford registration fees and/or equipment costs, or have played the necessary prerequisite years within a sport before. So, while a glance at a physical environment might suggest that a space is there for participation, a closer consideration of the social(ized) environment might reveal that having a space, alone, does not necessarily translate into use.

Perhaps there is no better example of this than what transpired at the pool. That is, though the physical space had been suitably co-created, the social space remained one characterized by closeted resentment and xenophobia. We would suggest that without us being aware of this (through, for example, the anonymous article in Frank), minoritized individuals could still see and sense it, even when we allied participant-researchers are unaware. To help illustrate the sort of blindness of the normalized majority, consider that when we requested the pool supervisor consider offering a girls/women-only swim time once a week, the pool manager explained that because there was no expressed community need of this sort, it would not make sense to offer it. (This despite our request being, quite literally, an expression of interest.)

With respect to becoming (physically literate), we know that these conclusions are based, almost entirely, on the youth participants' own self-appraisals. That is, while it is possible for us to conclude that the youth participants believe they are more motivated, confident, and/or physically active, we also recognize that we are without any of the "objective" data some others might desire. Are they more motivated and confident, simply because they say so? We would say that, yes, they likely are. We say this because they said this to us, repeatedly. Moreover, we watched every session. While doing so, we observed an increase in motivation and confidence. Similarly, are we to believe that they are now more physically active, again, just because they say so? Well, again, in addition to them repeatedly telling us about the increases in their physical activity, we have many first-hand observations of this. We live in a small town-as we explained, one in which you can walk anywhere. We have since seen many of these youth participants playing tennis and basketball in this community. We also know that the local Syrian group has now booked a school gymnasium for weekends. There, our female participants have been on one half of the gymnasium playing the sports we taught them as well as others. So, here we 
are trying to recognize that some others might suggest these outcomes ought to have been "measured" to "count." But, we believe the promise our youth participants shared is genuine and real. Moving forward, we and/or others might be well-served to investigate these outcomes further.

We were especially happy to see our youth participants feel like they belong (more) in their new community. Of course, we strongly believe they should always embrace their Syrian identities. However, that many came to feel more Canadian speaks, we believe, to their social integration, cultural orientation, and developing sense of belonging in a new country. We also think that these same things have allowed the youth participants to develop some social capital that they had until-then not been able to access. Indeed, one of the youth participants has since joined her school's junior varsity basketball team. Additionally, that some participants asked to bring some of their friends to some of the seasons' activities speaks, to us, to how their participation in this club gave them some capital with some of their Canadian classmates. We would suggest that their designed Syrian Youth Sports Club "uniforms" afforded them a marker of cultural capital too. As some of the participants observed, all of their Canadian classmates seemed to be sports players of some sort. Those peers, as do many youth who play sports, often wear their teams' jerseys or jackets to schools, sometimes in response to a school's theme day. Our participants wore their uniforms to school on all days that they had an after-school activity. And, more telling, they wore them to school on many other days.

It is also important for us to make mention of how parents/guardians provided both obstacles and opportunities. That is, we came to recognize that parents/guardians can be both "non-encouraging" and "supportive" with respect to sport and recreation participation. Many of their non-Syrian peers live in households where parents/guardians would be very actively encouraging their children to join teams or clubs. These parents/guardians have easier access to the sorts of teams and clubs that exist (i.e., they know about them and where to go for them). They also do not have to wrestle with the sorts of competing priorities our Syrian families recognize (e.g., learning English, "catching up" in school after years away from formal education, worshiping without a Mosque, etc.). So, we recognize why these parents/guardians might be less encouraging of sport and recreation participation. We have seen this before, in the literature and also with other immigrant newcomers. Nonetheless, the success of the Syrian Youth Sports Club required parents/guardians to be supportive of our co-created program. And, they were. For this, we are thankful. Their support did not come by chance, nor by blind trust. Rather, we met with them as we began and we constantly in communication with parents/guardians throughout the process. We earned their trust and they paid us back by supporting their children's continued involvement.

\section{Conclusions}

The most difficult and as-of-yet unmentioned aspect of this Syrian Youth Sports Club is where to go with it now. While we have worked alongside our youth participants to identify and address/embrace obstacles/opportunities, and then design and experience the four-season schedule, we are left wondering, "What now?" More importantly, our youth participants are wondering the same thing.

We suppose that in an ideal world, our youth participants would now have the necessary tools to identify and address and embrace their future obstacles and opportunities. Indeed, we did this already with them. We modeled it. But, they are youth. Some are children. We believe those who provide sport and recreation programs in the community ought to take up some of this responsibility. That is, if they want our local Syrian youth refugees to be included in their sport and recreation programs, they need to make them (more) accessible. They have a role to play here. And, simply declaring that are all welcome is not a welcoming act, at all. That has not worked in the past. We offer possibilities for the future.

We would like to think that we have only opened a door and that others needs to come through the figurative doorway. It is not as though we wish to step aside. Rather, we can continue to hold this door open, and we can at the same time work alongside others as we welcome them through. In the literal sense, this means that we will soon share this very project with local and provincial leaders in 
sport and recreation. We will tell them what we have learned, and we will invite our youth participants to share in this exercise. We will also secure additional funding so that we may continue to do this important work with these youth and others moving forward.

Our hope is that others will do the same.

Author Contributions: Authors contributed to the manuscript as follows: conceptualization, D.B.R., I.M.R., V.C. and N.H.; data curation, D.B.R. and I.M.R.; formal analysis, D.B.R. and I.M.R.; funding acquisition, D.B.R.; investigation, D.B.R., I.M.R. and V.C.; methodology, D.B.R., I.M.R., V.C. and N.H.; project administration, D.B.R., I.M.R. and V.C.; resources, D.B.R., I.M.R. and V.C.; supervision, D.B.R., I.M.R. and V.C.; validation, D.B.R. and I.M.R.; visualization, D.B.R.; writing—original draft, D.B.R.; writing—reviewing and editing, D.B.R., I.M.R, V.C. and N.H.

Funding: This research was funded by a Community Development Grant (PI: D.R.) from Nova Scotia Communities, Culture and Heritage (Communities, Sport and Recreation) and by a University Council for Research Grant (P.I.: D.R.) from St. Francis Xavier University.

Acknowledgments: We wish to acknowledge the participation and support given by our various community partners (individuals and organizations).

Conflicts of Interest: The authors declare no conflict of interest.

\section{References}

Anonymous. 2019. A funny thing happened on the way to the Little Vatican. Frank 807: 32

Bernard, H. Russell, and Gery W. Ryan. 1998. Text analysis: Qualitative and quantitative methods. In Handbook of Methods in Cultural Anthropology. Edited by H. Russell Bernard. Lanham: AltaMira Press.

Boyatzis, Richard E. 1998. Transforming Qualitative Information: Thematic Analysis and Code Development. Thousand Oaks: Sage Publications.

Brewer, Mackenzie, and Rachel Tolbert Kimbro. 2014. Neighborhood context and immigrant children's physical activity. Social Science \& Medicine 116: 1-9.

Creswell, John W. 2012. Educational Research: Qualitative, Quantitative, and Mixed Methods Approaches, $2 \mathrm{nd}$ ed. Thousand Oaks: Sage Publications.

Culp, Brian. 2010. Are your S's in effect? Ensuring culturally responsive physical education environments. Strategies 24: 10-14. [CrossRef]

Currie, Vanessa, and Cheryl Heykoop. 2011. CPP Circle of Rights Workbook Series: Reflective Planning for Social Change. Vancouver: International Institute for Child Rights and Development.

Dagkas, Symeon, Tansin Benn, and Haifaa Jawad. 2011. Multiple voices: Improving participation of Muslim girls in physical education and school sport. Sport, Education and Society 16: 223-39. [CrossRef]

Dogra, Shilpa, Brad A. Meisner, and Chris I. Ardern. 2010. Variation in mode of physical activity by ethnicity and time since immigration: A cross-sectional analysis. International Journal of Behavioral Nutrition and Physical Activity 7: 75-86. [CrossRef] [PubMed]

Doherty, Alison, and Tracy Taylor. 2007. Sport and physical recreation in the settlement of immigrant youth. Leisure/Loisir 31: 27-55. [CrossRef]

Edwards, Lowri C., Anna S. Bryant, Richard J. Keegan, Kevin Morgan, and Anwen M. Jones. 2017. Definitions, foundations and associations of physical literacy: A systematic review. Sports Medicine 47: 113-26. [CrossRef]

Eime, Rochelle M., Janet A. Young, Jack T. Harvey, Melanie J. Charity, and Warren R. Payne. 2013. A systematic review of the psychological and social benefits of participation in sport or children and adolescents: Informing development of a conceptual model of health through sport. International Journal of Behavioral Nutrition and Physical Activity 10: 155-65. [CrossRef]

Erkut, Sumru, and Allison J. Tracy. 2002. Predicting adolescent self-esteem from participation in school sports among Latino subgroups. Hispanic Journal of Behavioral Science 24: 409-29. [CrossRef]

Ferkins, Lesley, Gael McDonald, and David Shilbury. 2010. A model for improving board performance: The case of a national sport organisation. Journal of Management \& Organization 16: 601-21.

Fernandez-Kelly, M. Patricia, and Richard Schauffler. 1994. Divided fates: Immigrant children in a restructured economy. International Migration Review 28: 662-89. [CrossRef]

Frisby, Wendy, Colleen J. Reid, Sydney Millar, and Larena Hoeber. 2005. Putting "participatory" into participatory forms of action research. Journal of Sport Management 19: 367-86. [CrossRef] 
Goldfield, Gary S., Katherine Henderson, Annick Buchholz, Nicole Obeid, Hien Nguyen, and Martine F. Flament. 2011. Physical activity and psychological adjustment in adolescents. Journal of Physical Activity and Health 8 : 157-63. [CrossRef] [PubMed]

Holt, Nicholas L., Bethan C. Kingsley, Lisa N. Tink, and Jay Scherer. 2011. Benefits and challenges associated with sport participation by children and parents from low-income families. Psychology of Sport and Exercise 12: 490-99. [CrossRef]

Kemmis, Stephen. 2006. Participatory action research and the public sphere. Educational Action Research 14: 459-76. [CrossRef]

Kemmis, Stephen, Robin McTaggart, and John Retallick. 2004. The Action Research Planner. Karachi: Aga Khan University, Institute for Economic Development.

Kemmis, Stephen, Robin McTaggart, and Rhonda Nixon. 2014. The Action Research Planner: Doing Critical Participatory Action Research. New York: Springer.

Kimbro, Rachel Tolbert, and Bhavika Kaul. 2016. Physical activity disparities between US-born and immigrant children by maternal region of origin. Journal of Immigrant and Minority Health 18: 308-17. [CrossRef] [PubMed]

Lichter, Daniel T. 2013. Integration or fragmentation? Racial diversity and the American future. Demography 50: 359-91. [CrossRef]

Livingston, Lori A., and Susan Tirone. 2012. Understanding structural barriers in amateur sport and the participation of immigrants in Atlantic Canada. In Race and Sport in Canada: Intersecting Inequalities. Edited by Janelle Joseph, Simon Darnell and Yuka Nakamura. Toronto: Canadian Scholars' Press, pp. 165-85.

Logan, John R., Wenquan Zhang, and Richard D. Alba. 2002. Immigrant enclaves and ethnic communities in New York and Los Angeles. American Sociological Review 67: 299-322. [CrossRef]

Loprinzi, Paul D., Bradley J. Cardinal, Kristina L. Loprinzi, and Hyo Lee. 2012. Benefits and environmental determinants of physical activity in children and adolescents. The European Journal of Obesity 5: 597-610. [CrossRef]

Miles, Matthew B., A. Michael Huberman, and Johnny Saldaña. 2014. Qualitative Data Analysis: A Methods Sourcebook, 3rd ed. Thousand Oaks: Sage Publications.

Portes, Alejandro. 1998. Social capital: Its origins and applications in modern sociology. Annual Review of Sociology 24: 1-24. [CrossRef]

Portes, Alejandro, and Rubén G. Rumbaut. 2001. Legacies: The Story of the Immigrant Second Generation. Berkeley: University of California Press.

Robinson, Daniel B., and Lynn Randall. 2016. (Un)holy spaces: A consideration of religious minorities within health and physical education. In Social Justice in Physical Education: Critical Reflections and Pedagogies for Change. Edited by Daniel B. Robinson and Lynn Randall. Toronto: Canadian Scholars' Press, pp. 206-47.

Robinson, Daniel B., and Lynn Randall. 2017. Marking physical literacy or missing the mark on physical literacy? A conceptual critique of Canada's physical iteracy assessment instruments. Measurement in Physical Education and Exercise Science 21: 40-55. [CrossRef]

Robinson, Daniel B., Lisa Lunney Borden, and Ingrid Robinson. 2013. Charting a course for culturally responsive physical education. Alberta Journal of Educational Research 58: 526-46.

Robinson, Daniel B., Lynn Randall, and Joe Barrett. 2018. Physical literacy (mis) understandings: What do physical education teacher leaders know about physical literacy? Journal of Teaching in Physical Education 37: 288-98. [CrossRef]

Sallis, James F., Judith J. Prochaska, and Wendell C. Taylor. 2000. A review of correlates of physical activity of children and adolescents. Medicine \& Science in Sports \& Exercise 32: 963-75.

Sherry, Emma, Nico Schulenkorf, Emma Seal, Matthew Nicholson, and Russell Hoye. 2017. Sport-for-development: Inclusive, reflexive, and meaningful research in low-and middle-income settings. Sport Management Review 20: 69-80. [CrossRef]

Singh, Gopal K., Stella M. Yu, Mohammad Siahpush, and Michael D. Kogan. 2008. High levels of physical inactivity and sedentary behaviors among US immigrant children and adolescents. Archives of Pediatrics and Adolescent Medicine 162: 756-63. [CrossRef] [PubMed]

Sohng, Sung Sil Lee. 1996. Participatory research and community organizing. Journal of Sociology E Social Welfare 23: 77-97. 
Spaaij, Ramón. 2012. Beyond the playing field: Experiences of sport, social capital, and integration among Somalis in Australia. Ethnic and Racial Studies 35: 1519-38. [CrossRef]

Spaaij, Ramón. 2015. Refugee youth, belonging and community sport. Leisure Studies 34: 303-18. [CrossRef]

Sport Canada. 2012. Canadian Sport Policy 2012. Available online: http://sirc.ca/sites/default/files/content/docs/ pdf/csp2012_en_lr.pdf (accessed on 25 April 2019).

Stanec, Amanda D., and Jennifer A. Bhalla. 2015. We Belong: A How-to-Guide. Improving Access to Physical Activity Programs for Newcomer Youth. Ottawa: Physical and Health Education Canada.

Stanec, Amanda D., Jennifer A. Bhalla, and James Mandigo. 2016. Exploring the issues faced by immigrant students in physical education. In Social Justice in Physical Education: Critical Reflections and Pedagogies for Change. Edited by Daniel B. Robinson and Lynn Randall. Toronto: Canadian Scholars' Press, pp. 248-70.

Strack, Robert, Kay Lovelace, Toshia Davis Jordan, and Anita Holmes. 2010. Framing photovoice using a social-ecological model as a guide. Health Promotion Practice 11: 629-36. [CrossRef]

Taylor, Tracy, and Alison Doherty. 2007. Adolescent sport, recreation and physical education: Experiences of recent arrivals to Canada. Sport, Education and Society 10: 211-38. [CrossRef]

Thivel, David, Laurie Isacco, Nordine Lazaar, Julien Aucouturier, Sébastien Ratel, Eric Doré, Martine Meyer, and Pascale Duché. 2011. Effect of a 6-month school-based physical activity program on body composition and physical fitness in lean and obese school children. European Journal of Pediatrics 170: 1435-43. [CrossRef] [PubMed]

Tirone, Susan, Lori A. Livingston, A. Jordan Miller, and Emma L. Smith. 2010. Including immigrants in elite and recreational sports: The experiences of athletes, sport providers and immigrants. Leisure/Loisir 34: 403-20. [CrossRef]

Tremblay, Mark S., Shirley N. Bryan, Claudio E. Pérez, Chris I. Ardern, and Peter T. Katzmarzyk. 2006. Physical activity and immigrant status. Canadian Journal of Public Heath 97: 277-82.

Van Ngo, Hieu. 2009. Patchwork, sidelining and marginalization: Services for immigrant youth. Journal of Immigrant \& Refugee Studies 7: 82-100.

van Wel, Frits, Hub Linssen, Toon Kort, and Ellen Jansen. 1996. Ethnicity and youth cultural participation in the Netherlands. Journal of Leisure Research 28: 85-95. [CrossRef]

van Wel, Frits, Nellie Couwenbergh-Soeterboek, Christianne Couwenbergh, Tom ter Bogt, and Quinten Raaijmakers. 2006. Ethnicity, youth cultural participation, and cultural reproduction in the Netherlands. Poetics 34: 65-82. [CrossRef]

Walseth, Kristin. 2008. Bridging and bonding social capital in sport-Experiences of young women with an immigrant background. Sport, Education and Society 13: 1-7. [CrossRef]

Yen, Irene H., and George A. Kaplan. 1999. Neighborhood social environment and the risk of death: Multilevel evidence from the Alamada County Study. American Journal of Epidemiology 149: 898-907. [CrossRef]

(C) 2019 by the authors. Licensee MDPI, Basel, Switzerland. This article is an open access article distributed under the terms and conditions of the Creative Commons Attribution (CC BY) license (http://creativecommons.org/licenses/by/4.0/). 
MDPI

St. Alban-Anlage 66

4052 Basel

Switzerland

Tel. +41 616837734

Fax +41 613028918

www.mdpi.com

Social Sciences Editorial Office

E-mail: socsci@mdpi.com

www.mdpi.com/journal/socsci

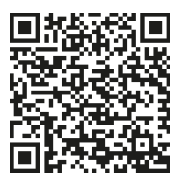



MDPI

St. Alban-Anlage 66

4052 Basel

Switzerland

Tel: +41 616837734

Fax: +41 613028918

www.mdpi.com 